\title{
Role and Contribution of A2 Adenosine Receptors in the Regulation of Coronary Flow
}

\author{
Maryam Sharifi Sanjani \\ West Virginia University
}

Follow this and additional works at: https://researchrepository.wvu.edu/etd

\section{Recommended Citation}

Sharifi Sanjani, Maryam, "Role and Contribution of A2 Adenosine Receptors in the Regulation of Coronary Flow" (2011). Graduate Theses, Dissertations, and Problem Reports. 4788.

https://researchrepository.wvu.edu/etd/4788

This Dissertation is protected by copyright and/or related rights. It has been brought to you by the The Research Repository @ WVU with permission from the rights-holder(s). You are free to use this Dissertation in any way that is permitted by the copyright and related rights legislation that applies to your use. For other uses you must obtain permission from the rights-holder(s) directly, unless additional rights are indicated by a Creative Commons license in the record and/ or on the work itself. This Dissertation has been accepted for inclusion in WVU Graduate Theses, Dissertations, and Problem Reports collection by an authorized administrator of The Research Repository @ WVU.

For more information, please contact researchrepository@mail.wvu.edu. 
Role and Contribution of $A_{2}$ Adenosine Receptors in the Regulation of Coronary Flow

$$
\text { Maryam Sharifi Sanjani }
$$

Dissertation submitted to the School of Pharmacy at West Virginia University in partial fulfillment of the requirements for the degree of

Doctor of Philosophy

in

Pharmaceutical and Pharmacological Sciences

S. Jamal Mustafa, Ph. D., Chair

Matthew Boegehold, Ph. D.

Robert Brock, Ph. D.

Jeffrey Fedan, Ph. D.

Jason Huber, Ph. D.

Department of Pharmaceutical and Pharmacological Sciences

Morgantown, West Virginia

2011

Keywords: Coronary flow; Adenosine; $\mathbf{A}_{2}$ adenosine receptors; Reactive oxygen species; Vascular tone; $\mathrm{K}^{+}$channels

Copyright 2011 Maryam Sharifi Sanjani 


\section{ABSTRACT \\ Role of $\mathbf{A}_{2}$ Adenosine Receptors in the Regulation of Coronary Flow}

\section{Maryam Sharifi Sanjani}

One out of three individuals suffer from one form of cardiovascular disease, out of which, about 6,000,000 individuals suffer from coronary heart disease. Adenosine has long been known to play a role in coronary flow $(\mathrm{CF})$ regulation; however, the individual role of $\mathrm{A}_{2 \mathrm{~A}}$ and $\mathrm{A}_{2 \mathrm{~B}}$ adenosine receptors (AR) and their contribution is yet to be fully elucidated. The purpose of this study was to characterize the pharmacology of both $\mathrm{A}_{2}$ ARs in coronary arteries (CAs), in addition, to identifying their role in reactive hyperemia, and their signaling mechanisms. We hypothesized that $\mathrm{A}_{2}$ ARs mediate an increase in $\mathrm{CF}$, in addition, to being involved in metabolic control of CF. Therefore, in this study, we investigated CF changes due to exogenous activation of $\mathrm{A}_{2 \mathrm{~A}}$ and $\mathrm{A}_{2 \mathrm{~B}} \mathrm{ARs}$, in addition, to their endogenous activation during coronary reactive hyperemia, when metabolic factors, such as adenosine, play a pivotal role. We used the well established Langendorff isolated heart system as well as selective and non-selective AR agonists and antagonists, and $\mathrm{A}_{2 \mathrm{~A}}$ and $\mathrm{A}_{2 \mathrm{~B}} \mathrm{AR}$ single and double knockout mice. We found that activation of both $\mathrm{A}_{2 \mathrm{~A}}$ and $\mathrm{A}_{2 \mathrm{~B}}$ ARs induces an increase in $\mathrm{CF}$, albeit with different pharmacological profile. Further, in $\mathrm{A}_{2 \mathrm{~B}} \mathrm{KO}$ mice, $\mathrm{A}_{2 \mathrm{~A}} \mathrm{ARs}$ are up-regulated in order to compensate for deletion of $\mathrm{A}_{2 \mathrm{~B}} \mathrm{ARs}$. These findings may suggest that both $\mathrm{A}_{2} \mathrm{ARs}$ are capable of increasing the $\mathrm{CF}$ in conditions when a sufficient level of adenosine is available. However, we also found that only $\mathrm{A}_{2 \mathrm{~A}} \mathrm{ARs}$ contribute to $\mathrm{CF}$ changes in coronary reactive hyperemia, which may suggest that $\mathrm{A}_{2 \mathrm{~B}} \mathrm{ARs}$ may be activated in more severe conditions such as longer ischemic conditions, where adenosine levels are significantly augmented. We next investigated signaling pathways involved 
in $\mathrm{A}_{2} \mathrm{AR}$-mediated effects. We found that non-mitochondrial $\mathrm{K}_{\mathrm{ATP}}$ channels are a major end effectors in $\mathrm{A}_{2} \mathrm{AR}$-induced increase in $\mathrm{CF}$. What is more interesting is that we illustrated that $\mathrm{H}_{2} \mathrm{O}_{2}$ mediates adenosine's effect on $\mathrm{CF}$ and that is coupled to adenosine-mediated effect on $\mathrm{K}_{\mathrm{ATP}}$ channels. From these data, it can be concluded that $\mathrm{A}_{2 \mathrm{~A}}$ and $\mathrm{A}_{2 \mathrm{~B}} \mathrm{ARs}$ may regulate $\mathrm{CF}$ in different conditions, albeit, maybe through the same signaling pathway. 
To my grandmother, Sonia, Sister, Mana, Husband, Ali, and my father and mother, Nasser and Shahnaz 


\section{ACKNOWLEDGEMENT}

I am indeed and sincerely grateful to a number of people in bringing this dissertation to fruition. I thank my mentor Dr. Jamal Mustafa for his continuous help and concern. I am sincerely very grateful for his understanding and support and his immense care and concern even outside the laboratory. Many thanks to my dissertation committee: Dr.Boegehold, Dr. Fedan, Dr. Huber, and Dr. Brock for their time, advice, scientific expertise and guidance in helping me complete this dissertation project.

I worked with wonderful people in Dr. Mustafa's laboratory. Each of them has taught me a great deal in different levels. Thank you: Dr. Teng for your enthusiasm and being ready to help at any time; Dr. Ponnoth for being a very supportive friend during our time inside and outside the laboratory; my fellow students especially Swati Kunduri, who has been a kind friend; our previous lab technician, Kevin Roush; Dr. Stephen Tilley, University of North Carolina. I thank all the faculty and administrative staff from the Departments of Physiology\&Pharmacology and Pharmaceutical\&Pharmacological Sciences. Thanks especially to Vickie White, Debbie Beery, Claire Noel, and Brad Rager.

Last, but certainly not the least, I thank my family - my grandmother who's words and limitless and generous given love kept me going, my husband who's love and encouragement reminded me of who I am during tough times, my sister who's sincere love and support, although from far, made all life's ups and downs smoother, my father who was a role model in my life and always gave me a higher bar to reach and succeed, my mother without whom none of this would have been possible, my uncle Mahmoud whose support during my master's degree made the steps for my turning point, and my uncle Massoud for his time, love, and help. My expanded family has always been my 
strength and driving force; I could not have reached here without their love, support and constant encouragement. 


\section{TABLE OF CONTENTS}

Page

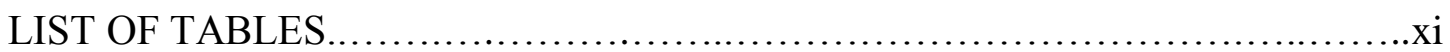

LIST OF FIGURES..............................................................

LIST OF ABBREVIATIONS ...........................................

CHAPTER ONE: INTRODUCTION........................................

Generation of adenosine and its metabolism ..............................2

Coronary flow regulation...........................................5

Role of adenosine in coronary flow regulation............................13

Adenosine receptors classification and characteristics..................... 14

Classically known signaling of adenosine receptors .......................19

Role of $\mathrm{K}^{+}$channels in $\mathrm{A}_{2 \mathrm{~A}} \mathrm{AR}$-mediated coronary flow regulation...........19

Role of $\mathrm{H}_{2} \mathrm{O}_{2}$ in $\mathrm{A}_{2 \mathrm{~A}} \mathrm{AR}$-mediated coronary flow regulation................21

Relationship between adrenoceptors (ADR) and $\mathrm{A}_{2} \mathrm{ARs}$ in coronary flow

regulation.......................................................22

Clinical applications..............................................23

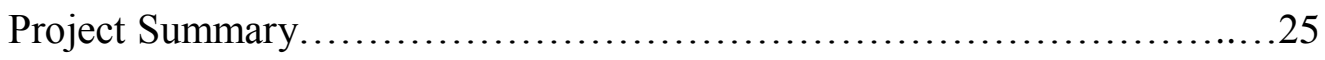

References........................................................26

CHAPTER TWO: RATIONALE AND LIMITATIONS ...........................48

CHAPTER THREE: CONTRIBUTIONS OF A 2A $_{\text {AND A }}$ AD ADENOSINE

RECEPTORS IN CORONARY FLOW RESPONSES IN RELATION TO K

CHANNELS USING $\mathrm{A}_{2 \mathrm{~B}}$ AND A $\mathrm{A}_{2 \mathrm{~A} / 2 \mathrm{~B}}$ DOUBLE KNOCKOUT MICE..............54

Abstract............................................................55

Introduction..................................................... 56 
Materials and methods.

Generation of DKO mice

WT, $\mathrm{A}_{2 \mathrm{~A}}$, and $\mathrm{A}_{2 \mathrm{~B}} \mathrm{KO}$ and $\mathrm{A}_{2 \mathrm{~A} / 2 \mathrm{~B}} \mathrm{DKO}$

Chemicals. .59

Langendorff-perfused mouse heart preparation.............60

Experimental protocol............................61

Western blot......................................62

Data and statistical analysis. ...........................63

Results.

Baseline function in WT, $\mathrm{A}_{2 \mathrm{~A}} \mathrm{KO}, \mathrm{A}_{2 \mathrm{~B}} \mathrm{KO}$, and $\mathrm{A}_{2 \mathrm{~A} / 2 \mathrm{~B}} \mathrm{DKO}$ isolated hearts.....................................63

Effect of $\mathrm{A}_{2 \mathrm{~B}} \mathrm{AR}$ activation on coronary flow .............64

Contribution of $\mathrm{A}_{2 \mathrm{~A}} \mathrm{AR}$ in ARs-mediated coronary vasodilation of $\mathrm{A}_{2 \mathrm{~B}} \mathrm{KO}$ mice.

Up-regulation of $\mathrm{A}_{2 \mathrm{~A}} \mathrm{AR}$ expression in $\mathrm{A}_{2 \mathrm{~B}} \mathrm{KO}$ isolated mesenteric arterioles .64

Up-regulation of $\mathrm{A}_{2 \mathrm{~A}} \mathrm{AR}$ in $\mathrm{A}_{2 \mathrm{~B}} \mathrm{KO}$ mice................65

Up-regulation of $\mathrm{A}_{2 \mathrm{~A}} \mathrm{AR}$ in $\mathrm{A}_{2 \mathrm{~B}} \mathrm{KO}$ mice.........................65

Involvement of $\mathrm{A}_{2 \mathrm{~A}}$ and $\mathrm{A}_{2 \mathrm{~B}} \mathrm{ARs}$ in producing coronary vasodilation .66

Involvement of $\mathrm{K}_{\mathrm{ATP}}$ channels in $\mathrm{A}_{2 \mathrm{~A}}$ and $\mathrm{A}_{2 \mathrm{~B}} \mathrm{ARs}$-induced

increase in coronary flow ............................66

Discussion. .78

References. 
CHAPTER FOUR: INTERACTION OF ADENOSINE $\mathrm{A}_{2 \mathrm{~A}}$ RECEPTORS, HYDROGEN PEROXIDE, AND ATP-DEPENDENT K ${ }^{+}$CHANNELS IN

CORONARY REACTIVE HYPEREMIA _.................................................... 98

Abstract.............................................................. 99

Introduction............................................... 100

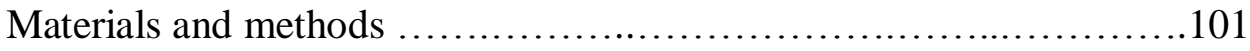

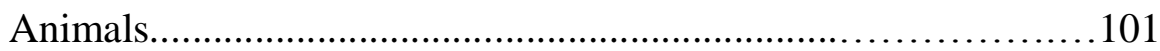

WT, $\mathrm{A}_{2 \mathrm{~A}}$, and $\mathrm{A}_{2 \mathrm{~B}} \mathrm{KO}$ and $\mathrm{A}_{2 \mathrm{~A} / 2 \mathrm{~B}} \mathrm{DKO}$ mice....................101

Langendorff-perfusion......................................... 101

Patch clamp................................................ 102

Statistical Analysis................................................ 103

Results...................................................103

Involvement of $\mathrm{A}_{2 \mathrm{~A}} \mathrm{ARs}$ in coronary reactive hyperemia ........103 $\mathrm{A}_{2 \mathrm{~B}} \mathrm{ARs}$ may not be involved in coronary reactive hyperemia ...103 Involvement of only $\mathrm{A}_{2} \mathrm{ARs}$ in coronary reactive hyperemia......103 Adenosine activates $\mathrm{K}_{\mathrm{ATP}}$ channels ............................104 Involvement of $\mathrm{H}_{2} \mathrm{O}_{2}$ in adenosine-induced increase in coronary flow................................................... 104 Involvement of $\mathrm{H}_{2} \mathrm{O}_{2}$ in coronary reactive hyperemia...........105 Involvement of $\mathrm{H}_{2} \mathrm{O}_{2}$ in $\mathrm{A}_{2} \mathrm{AR}$-mediatesd coronary reactive hyperemia............................................. 105

$\mathrm{H}_{2} \mathrm{O}_{2}$ activates $\mathrm{K}_{\text {ATP }}$ channels............................. 106

Discussion........................................................... 117 
References....................................................... 123

CHAPTER FIVE: CONCLUSIONS AND FUTURE DIRECTION......................132

References..................................................141

PUBLICATIONS AND ABSTRACTS............................................. 142

APPENDIX A: Preliminary experiments (relationship between adenosine receptors

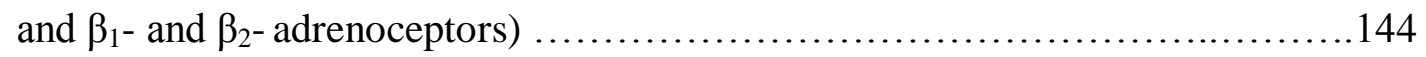

APPENDIX B: American Journal of Physiology copyright permission.............147

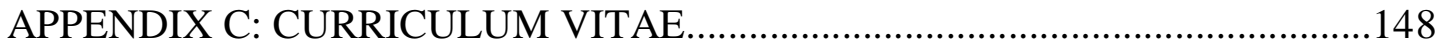




\section{LIST OF TABLES}

Page

Table 3.1: Baseline data for WT, $\mathrm{A}_{2 \mathrm{~A}} \mathrm{KO}, \mathrm{A}_{2 \mathrm{~B}} \mathrm{KO}$, and $\mathrm{A}_{2 \mathrm{~A} / 2 \mathrm{~B}} \mathrm{DKO}$ mice hearts.............77

Table 4.1: Resting flow, debt area (DA), peak flow, flow repayment area (RPA), and debt

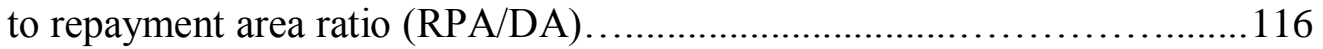




\section{LIST OF FIGURES}

Page

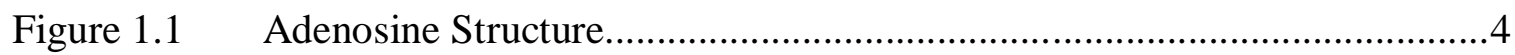

Figure 1.2 Production of adenosine under physiological conditions...........................

Figure 1.3 Several reported pathways for metabolic vasodilation of coronary

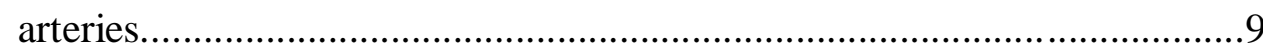

Figure 1.4 Previously reported major signal transduction pathways in the regulation

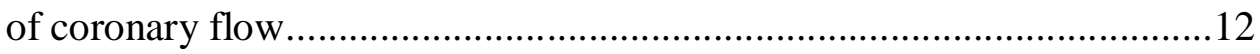

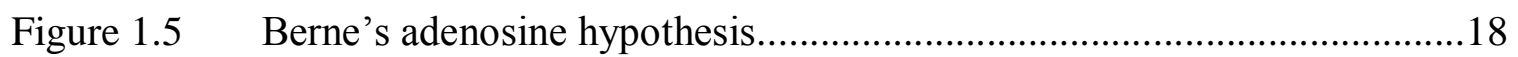

Figure 3.1 Effect of BAY 60-6583 in $\mathrm{A}_{2 \mathrm{~B}} \mathrm{KO}$ and WT mice on coronary flow, heart

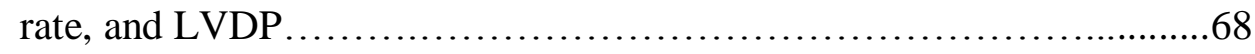

Figure 3.2 Effect of NECA in $\mathrm{A}_{2 \mathrm{~B}} \mathrm{KO}$ and WT mice on coronary flow, heart rate, and LVDP .69

Figure 3.3 $\mathrm{A}_{2 \mathrm{~A}} \mathrm{AR}$ expression levels in $\mathrm{WT}$ and $\mathrm{A}_{2 \mathrm{~B}} \mathrm{KO}$ isolated mesenteric arterioles. .70 
Figure 3.4 Effect of CGS 21680 in $\mathrm{A}_{2 \mathrm{~B}} \mathrm{KO}$ and WT mice on coronary flow, heart rate, and LVDP

Figure 3.5 Effect of SCH 58261 on NECA-induced increase in coronary flow, heart rate, and LVDP in $\mathrm{WT}$ and $\mathrm{A}_{2 \mathrm{~B}} \mathrm{KO}$ mice.

Figure 3.6 Effect of NECA in $\mathrm{A}_{2 \mathrm{~A} / 2 \mathrm{~B}} \mathrm{DKO}$ and WT mice on coronary flow, heart rate, and LVDP 73

Figure 3.7 Effect of 5-hydroxydecanote on NECA-induced increase in coronary flow, heart rate, and LVDP in WT and the effect of glibenclamide on NECA and pinacidil-induced increase in coronary flow, heart rate, and LVDP in WT.

Figure 3.8 Effect of glibenclamide on NECA-induced increase in coronary flow, heart rate, and LVDP in $\mathrm{A}_{2 \mathrm{~A}} \mathrm{KO}$ and $\mathrm{A}_{2 \mathrm{~B}} \mathrm{KO}$ .75

Figure 3.9 Effect of glibenclamide on CGS 21680- and BAY 60-6583-induced increase in coronary flow, heart rate, and LVDP in WT .76

Figure 4.1 Repayment volume, but not resting flow or peak flow, is reduced in $\mathrm{A}_{2 \mathrm{~A}} \mathrm{KO}$ mice, compared with WT, in coronary $\mathrm{RH}$. 
Figure 4.2 Baseline coronary flow, peak flow, and flow repayment area of coronary $\mathrm{RH}$ are normal in $\mathrm{A}_{2 \mathrm{~B}} \mathrm{KO}$ mice compared with WT

Figure 4.3 Changes on coronary flow, peak flow, and flow repayment area in WT

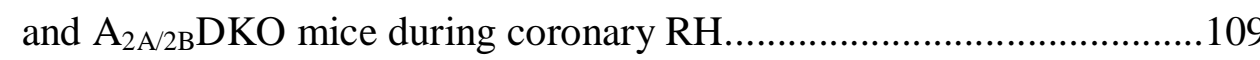

Figure 4.4 Adenosine-mediated increase in glibenclamide-sensitive conductance is attenuated in $\mathrm{A}_{2 \mathrm{~A} / 2 \mathrm{~B}} \mathrm{DKO}$ mice. 110

Figure 4.5 Attenuated adenosine-induced increase in coronary flow and LVDP, and normal heart rate, in $\mathrm{WT}, \mathrm{A}_{2 \mathrm{~A}} \mathrm{KO}$, and $\mathrm{A}_{2 \mathrm{~B}} \mathrm{KO}$ mice, in the presence of catalase

Figure 4.6 Attenuated peak flow and repayment area, but normal baseline CF, in the presence of catalase in WT mice.

Figure 4.7 Reactive hyperemia-induced changes on coronary flow, peak flow, and flow repayment area in the presence and absence of catalase in $\mathrm{A}_{2 \mathrm{~A}} \mathrm{KO}$ mice.

Figure $4.8 \quad \mathrm{H}_{2} \mathrm{O}_{2}$ induces an increase in glibenclamide-sensitive conductance in smooth muscle cells. 
Fig. 4.9 Effect of catalase on adenosine and pinacidil mediated increase in glibenclamide-sensitive conductance $(\mathrm{nS} / \mathrm{pF})$ in WT smooth muscle cells.................................................................. 115

Figure 5.1 Suggested signaling pathways for $\mathrm{A}_{2 \mathrm{~A}^{-}}$and $\mathrm{A}_{2 \mathrm{~B}} \mathrm{ARs}-$ mediated $\mathrm{CF}$

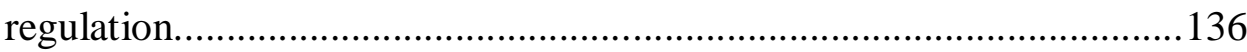

Figure 5.2 Future directions for identifications of $\mathrm{A}_{2 \mathrm{~A}} \mathrm{ARs}$ and $\mathrm{A}_{2 \mathrm{~B}} \mathrm{ARs}$ signaling

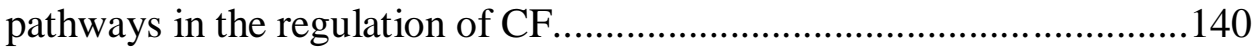




\section{LIST OF ABBREVIATIONS}

$\mu g$

$\mu 1$

$\mathrm{A}_{1} \mathrm{AR}$

$\mathrm{A}_{2 \mathrm{~A}} \mathrm{AR}$

$\mathrm{A}_{2 \mathrm{~B}} \mathrm{AR}$

$\mathrm{A}_{3} \mathrm{AR}$

$\mathrm{AC}$

ADA

$\mathrm{AD}$

ADP

ADR

AK

AMP

ANOVA

ATP

BAY

$\mathrm{BKCa}$

cAMP

cGMP

CGS 21860 micro gram

micro liter

$A_{1}$ adenosine receptor

$\mathrm{A}_{2 \mathrm{~A}}$ adenosine receptor

$\mathrm{A}_{2 \mathrm{~B}}$ adenosine receptor

$\mathrm{A}_{3}$ adenosine receptor

Adenylyl cyclase

Adenosine deaminase

Adenosine

Adenosine diphosphate

Adrenoceptors

Adenosine kinase

Adenosine monophosphate

Analysis of variance

Adenosine triphosphate

BAY60-6583 compound

$\mathrm{Ca}^{2+}$-activated $\mathrm{K}$ channels

Cyclic adenosine monophosphate

Cyclic guanosine monophosphate

2-p-(2-carboxyethyl)phenethylamino-

5' N-ethylcarboxy amidoadenosine

hydrochloride 


\begin{tabular}{|c|c|}
\hline $\mathrm{CF}$ & Coronary flow \\
\hline $\mathrm{CA}$ & Coronary artery \\
\hline Cat & Catalase \\
\hline CRC & Concentration-response curve \\
\hline DAG & Diacylglycerol \\
\hline $\mathrm{DKO}$ & Double knockout \\
\hline DMSO & Dimethyl sulfoxide \\
\hline DPCPX & 1,3-Dipropyl-8-cyclopentylxanthine \\
\hline EDHF & Endothelium-derived hyperpolarizing Factor \\
\hline EETs & Epoxyeicosatrienoic acids \\
\hline ERK1/2 & Extracellular signal-regulated kinase 1/2 \\
\hline GB & Glibenclamide \\
\hline GPCR & G protein coupled receptor \\
\hline 5-HD & 5-Hydroxydecanoate \\
\hline $\mathrm{H}_{2} \mathrm{O}_{2}$ & Hydrogen peroxide \\
\hline HR & Heart rate \\
\hline $\mathrm{IP}_{3}$ & Inositol trisphosphate \\
\hline $\mathrm{K}_{\text {ATP }}$ & ATP-dependent $\mathrm{K}^{+}$channels \\
\hline $\mathrm{kg}$ & Kilogram \\
\hline Kir & Inward rectifier $\mathrm{K}^{+}$channels \\
\hline $\mathrm{KO}$ & Knock out \\
\hline $\mathrm{K}_{\mathrm{V}}$ & Voltage-dependent $\mathrm{K}^{+}$channels \\
\hline LVDP & Left ventricle developed pressure \\
\hline MAPK & mitogen-activated protein kinase \\
\hline
\end{tabular}




\begin{tabular}{|c|c|}
\hline $\mathrm{mg}$ & milligram \\
\hline $\mathrm{ml}$ & milliliter \\
\hline $\mathrm{mm}$ & millimeter \\
\hline $\mathrm{mM}$ & millimole \\
\hline NADPH Ox & NADPH oxidase \\
\hline NECA & N-ethylcarboxamide-adenosine \\
\hline $\mathrm{NO}$ & Nitric oxide \\
\hline PCR & Polymerase chain reaction \\
\hline Pin & Pinacidil \\
\hline PKA & Protein kinase $\mathrm{A}$ \\
\hline PKC & Protein kinase $\mathrm{C}$ \\
\hline PLC & Phospholipase C \\
\hline $\mathrm{PO}_{2}$ & myocardial oxygen tension \\
\hline RH & Reactive hyperemia \\
\hline ROS & Reactive oxygen species \\
\hline $\mathrm{SAH}$ & S-Adenosyl-L-homocysteine \\
\hline SAH-hydrolase & S-Adenosyl-L-homocysteine-hydrolase \\
\hline SAM & S-Adenosyl-L methionine \\
\hline \multirow[t]{3}{*}{ SCH58261 } & 2-(2-Furanyl)-7-(2-phenylethyl)-7H- \\
\hline & pyrazolo[4,3-e][1,2,4]triazolo[1,5- \\
\hline & $c$ ]pyrimidine-5-amine \\
\hline SEM & Standard error of the mean \\
\hline Xanthine Ox & Xanthine oxidase \\
\hline
\end{tabular}


CHAPTER ONE

INTRODUCTION 
Adenosine, produced by all cells, is an endogenous purine nucleoside with various physiological effects induced through its four subtypes of receptors $A_{1}, A_{2 A}, A_{2 B}$, and $A_{3}$. Figure 1.1 illustrates the chemical structure of adenosine. Adenosine induces its effects All adenosine receptors (AR) are G protein coupled receptors (GPCR) and have their own pharmacological profile and affinity for adenosine, tissue distribution, and effector coupling. Therefore, effects mediated through adenosine depend on the AR subtype activated.

\section{Generation of adenosine and its metabolism}

In physiological conditions, adenosine is produced from intracellular conversion of S-adenosyl-L methionine (SAM) to S-adenosyl-L-homocysteine (SAH) which then is converted to adenosine and homocysteine by SAH-hydrolase $(30,48)$ (Figure 1.2). Cytosolic adenosine can become phosphorylated via adenosine kinase to AMP in addition to getting converted to inosine by adenosine deaminse (ADA), especially at high levels of adenosine. Intracellular adenosine is transported down the concentration gradient into the extracellular space via equillibrative membrane transporters. Adenosine can also be produced extracellular through successive dephosphorylation of ATP to ADP and then ADP to AMP, which then goes under hydrolysis via membrane-bound ecto-5'nucleotidases CD39 and CD73 in order to form adenosine. By the action of ADA, extracellularly produced adenosine can also be further converted to inosine which is finally broken down to uric acid that is excreted in urine. However, adenosine can also get re-converted to AMP via the enzyme adenosine kinase (AK). Nevertheless, extracellularly produced adenosine can also be transported into the cell via concentrationand/or sodium-dependent transporters (Figure 1.2). In addition to being metabolized, 
adenosine acts on its specific receptors to induce various physiological effects $(43,48$, 82). 
Figure 1.1 Adenosine structure

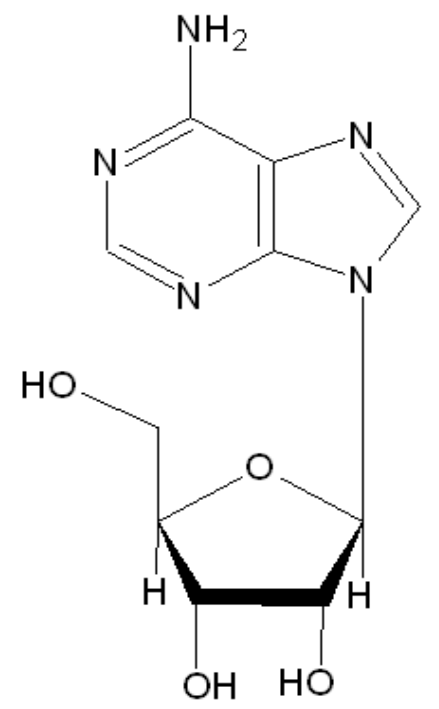

Figure 1.2 Production of adenosine under physiological conditions. Scheme adapted from Koos et al. (82)

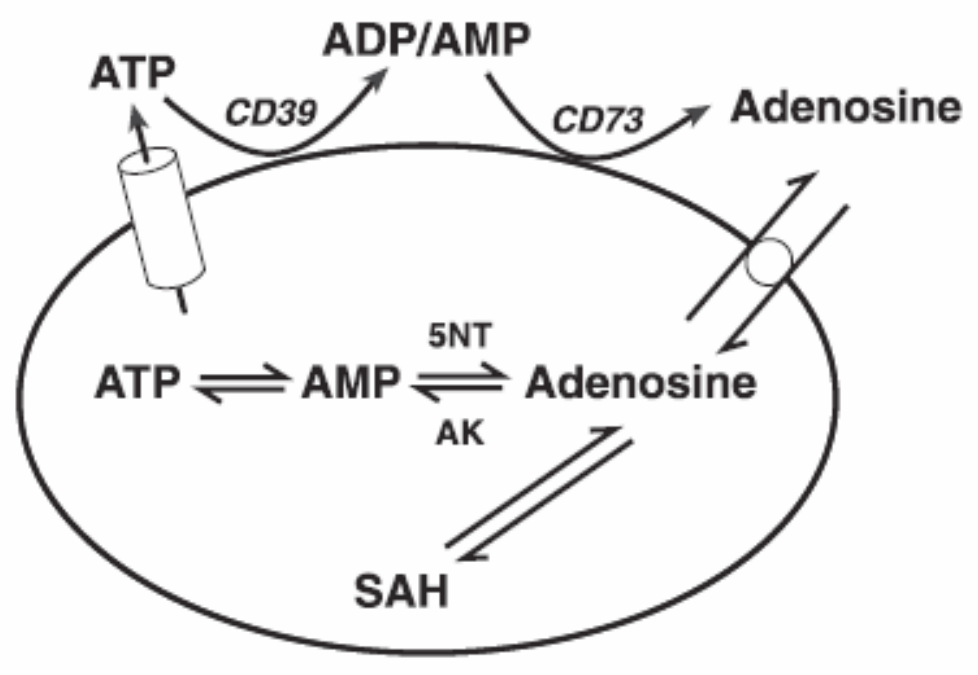




\section{Coronary flow regulation}

Coronary arteries (CAs) play a pivotal role in determining the oxygen and nutrient supply of the myocardium by regulating the coronary flow (CF). Myocardial perfusion is regulated by several factors released from endothelial cells, smooth muscle cells, and cardiomyocytes that affect the coronary vascular tone. It is well known that physical forces induce coronary responses known as myogenic and flow-induced (shear stress) vascular control that determine the vascular basal tone and CF (Figure 1.3). Also, metabolic factors such as adenosine have been shown to mediate CA responses during metabolic stimulation (active hyperemia), autoregulation, and/or reactive hyperemia (Figure 1.3). Moreover, sympathoneural factors such as the effect of $\beta$ adrenoceptors (ADR) are reported to affect the coronary tone through endothelium-dependent and independent manners (Figure 1.3).

Pressure-induced myogenic constriction importantly contributes to autoregulation of local blood flow, which also acts as a protective measure from sudden increases in arterial pressure (88). Given that this constriction allows resistance arteries, such as coronary arterioles, to constrict or dilate in response to vasoactive mediators and changes in intraluminal pressure, it counts as an essential component of basal microvascular tone where vascular resistance is tightly regulated (19). The myogenic response occurs independently of the endothelium and perivascular nerves and is, therefore, an inherent property of vascular smooth muscle cells $(85,98)$. Smooth muscle cells have stretchactivated cation channels that, when activated, induce an inward current leading to cell membrane depolarization and constriction $(22-23,160)$. Previous studies have shown that increased intraluminal pressure leads to depolarization of smooth muscle cells and the

opening of $\mathrm{Ca}^{2+}$ channels, such as $\mathrm{Ca}^{2+}$-activated $\mathrm{K}$ channels $(\mathrm{BKCa})$, responsible for 
increased intracellular $\mathrm{Ca}^{2+}$ leading to the contraction and the increase in myogenic tone (53-54, 108). Several endogenous mediators, such as cytochrome P450 metabolites, have been suggested to be involved in myogenic tone control via activation of $\mathrm{BKCa}$ channels (158). The CA myogenic tone is also proposed to be regulated by several molecular signaling pathways, such as, PKC pathway $(29,83,99)$ and MAPK/ERK1/2 pathway (76-78). Moreover, the myogenic constriction in CA is suggested to antagonize EDHFmediated dilation; it was reported that activation of $\mathrm{BKCa}$ channels reduces myogenic constriction and profoundly increases EDHF-mediated dilation in CA (54).

An increase in wall shear stress results in the release of various factors from the endothelium that subsequently act on smooth muscle cells in order to induce vasodilation $(86,122,150,165)$. This illustrates the release of endothelium-derived factors that may limit myogenic constriction. Endothelium-derived nitric oxide (NO), suggested as endothelium-derived relaxing factor (EDRF), was proposed to regulate the coronary reactive hyperemia responses $(80,150,165)$. However, other non-NO and non-prostanoid endothelium-derived substances, referred to as endothelium-derived hyperpolarizing factors (EDHFs), were found to play an important role in the regulation of CA vascular tone. Epoxyeicosatrienoic acids (EETs) $(46,128), \mathrm{H}_{2} \mathrm{O}_{2}(96,101,163)$, and $\mathrm{K}^{+}(6)$ are a few suggested EDHFs in coronary arteries to highlight. Liu et al. showed that endothelial-derived $\mathrm{H}_{2} \mathrm{O}_{2}$ was critical in human CA dilation to shear stress $(90,101)$. The same group also suggested that mitochondria are the source of the $\mathrm{H}_{2} \mathrm{O}_{2}$ generation that plays a role in flow-induced human CA dilation (90). Miura et al. reported that shear stress induces endothelium-dependent vasodilation through CYP450 metabolites leading to hyperpolarization of smooth muscle cells through BKCa channels in human coronary arterioles (103). It should be highlighted that human CAs in these studies are dissected 
from patients with cardiovascular disease, which may lead to different physiological responses than true controls, the tissues from healthy individuals. Nevertheless, previous studies have shown that endothelial production of NO can be triggered by mechanical shear forces or CF-induced pulsatile strain (154-155). It was demonstrated that NO contributes to the coronary responses in reactive hyperemia (167)and that adenosine is involved in CA flow-induced dilation and enhanced coronary response to pulsatile perfusion(87, 117, 169), which suggests the existence of a cooperative interaction between adenosine and the local flow regulation mechanisms.

It is well established that CF is regulated by the metabolic state of the heart (44) (Figure 1.3). Berne's adenosine hypothesis suggests that increases in myocardial oxygen consumption decreases myocardial oxygen tension $\left(\mathrm{pO}_{2}\right)$ which leads to the release of adenosine from cardiomyocytes $(8,43,159)$. Furthermore, a role for $\mathrm{H}_{2} \mathrm{O}_{2}$ in metabolic CA vasodilation has been established $(72,116,164)$. Chilian et al. suggested that $\mathrm{H}_{2} \mathrm{O}_{2}$ production increases in proportion to cardiac metabolism in order to couple the coronary blood flow to myocardial oxygen tension (131). On the other hand, increasing evidence has shown the involvement of $\mathrm{K}_{\mathrm{ATP}}$ channels in metabolic $\mathrm{CF}$ adjustment through different approaches such as pacing-induced tachycardia (73), pharmacological metabolic stimulation (110), and exercise (36). Further, coronary arteriolar smooth muscle $\mathrm{K}_{\mathrm{ATP}}$ channels $(42,124-125)$ and $\mathrm{BKCa}$ channels were reported to contribute to the basal $\mathrm{CF}$ regulation (53). There is evidence that during exercise, coronary NO production is increased in the heart (136), likely due to an increase in endothelial shear stress secondary to the increased CF rate $(9,149)$. Nevertheless, Chilian et al. demonstrated that CA vasoconstriction induced by inhibition of NO was counterbalanced by coronary vasodilation, indicating that many compensatory vasomotor adjustments occur in order to 
maintain the $\mathrm{CF}$ (71). And finally, the knowledge that prostaglandins may also act as local chemical mediators to control coronary perfusion to adapt to the metabolic demands of the heart should be considered (135). 
Figure 1.3 Several reported pathways for metabolic vasodilation of coronary arteries. Scheme adapted from Koos et al. (82).

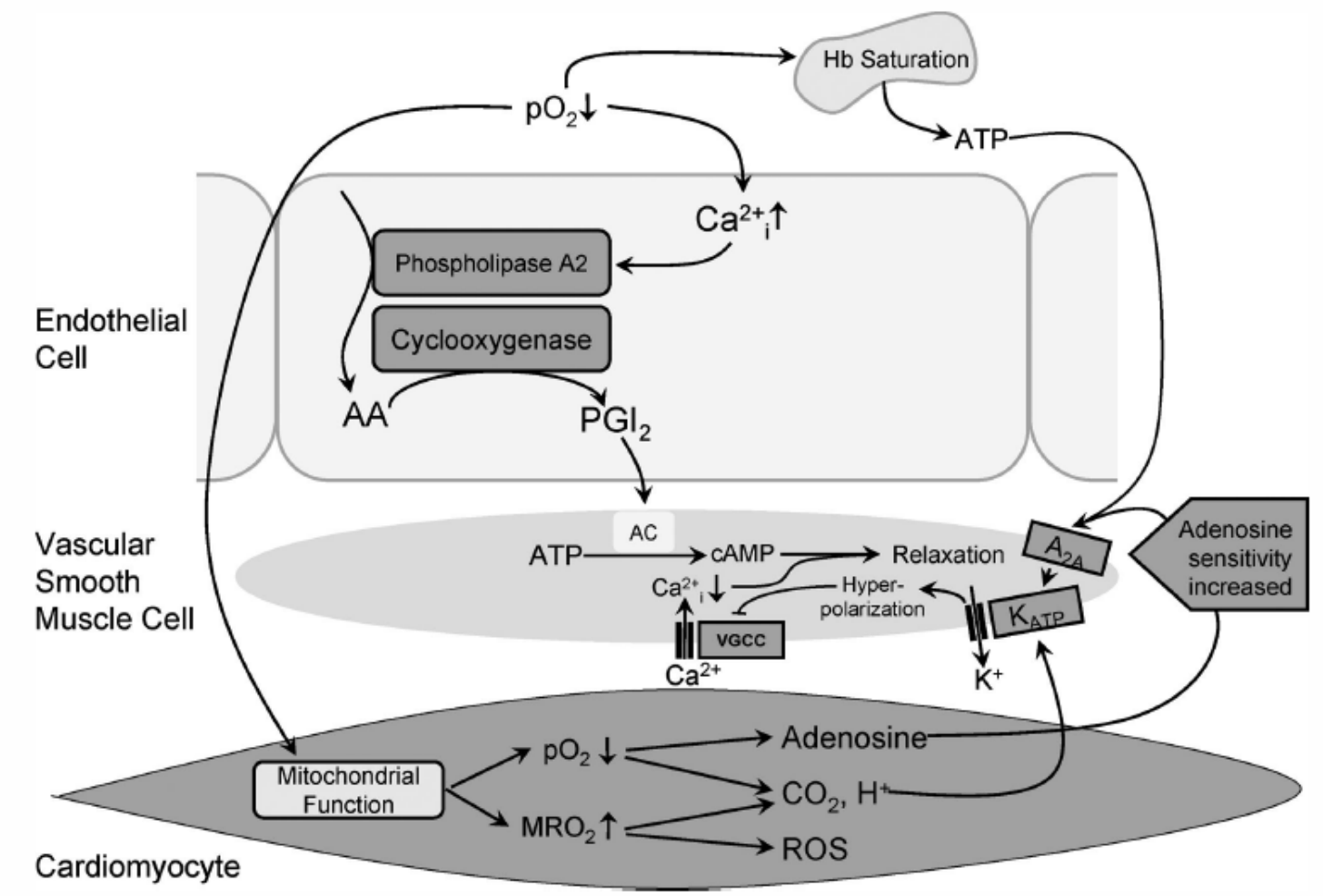


It has been known that neurotransmitters released from nerve endings are known to affect the coronary vascular tone. Sympathetic stimulation-mediated coronary vasoconstriction is capable of competing with local metabolic control to lower coronary venous oxygen tension (44). The autonomic effects on $\mathrm{CF}$ regulation have been studied at rest and during exercise through different approaches such as after surgical or chemical denervation of the heart or in the presence of selective autonomic receptor antagonists. It was reported that cardiac neural ablation did not impair the ability to maintain the exercise level, although the initial hemodynamic adjustment to exercise was delayed (52). It is established that blockade of $\alpha_{2}$-adrenoceptors (ADR) can affect the CF through three mechanisms: a) blockade of prejunctional $\alpha \mathrm{ADR}$ which interrupts the negative-feedback control of norepinephrine release leading to an increase in norepinephrine levels and induction of cardiac BADR stimulation and an increase in $\mathrm{CF}(60,62)$; b) $\alpha \mathrm{ADR}$ blockade can increase CF by interrupting vasoconstriction mediated by postjunctional $\alpha_{1}$ and $\alpha_{2} \mathrm{ADRs}$ located on CA smooth muscle cells; and c) $\alpha_{2} \mathrm{ADR}$ on CA endothelial cells can stimulate release of nitric oxide (NO), which can oppose the aADR-mediated vasoconstriction $(20,65)$. On the other hand, it was reported that norepinephrine brings about human coronary vasodilation through $\beta_{2} \mathrm{ADR}$ (139) that involves $\mathrm{NO}$ and $\mathrm{K}_{\mathrm{ATP}}$ channels (100). Previous studies suggested that $\beta_{2} \mathrm{ADR}$-mediated $\mathrm{CF}$ regulation is minimal under resting conditions in $\operatorname{dogs}(5,61)$ while, $\beta$ ADRactivation was shown to contribute to coronary vasodilation during exercise in a feed-forward manner (104-105, 153). $\beta_{2} \mathrm{ADR}$ activation during exercise causes a significant degree of CA dilatation independent of myocardial effects of $\beta_{1}$ ADR stimulation $(31,94)$. Overall, the consensus is that $\beta \mathrm{ADR}$ blockade causes a greater reduction in $\mathrm{CF}$ compared to myocardial oxygen 
consumption, resulting in increased oxygen extraction by the heart which demonstrates a direct feed-forward for $\beta$ ADR CA vasodilatory effect.

In this thesis, based on previous studies on adenosine and the existence of broad factors involved in the regulation of $\mathrm{CF}$, we elaborate on the role of adenosine, $\mathrm{K}_{\mathrm{ATP}}$ channels, and $\mathrm{H}_{2} \mathrm{O}_{2}$ in addition to a brief look at $\beta$ adrenoceptors, as a sympathoneural factor, in light of adenosine as the main focus. 
Figure 1.4 Previously reported major signal transduction pathways in the regulation of coronary flow. Adapted from Komaru et al. (81)

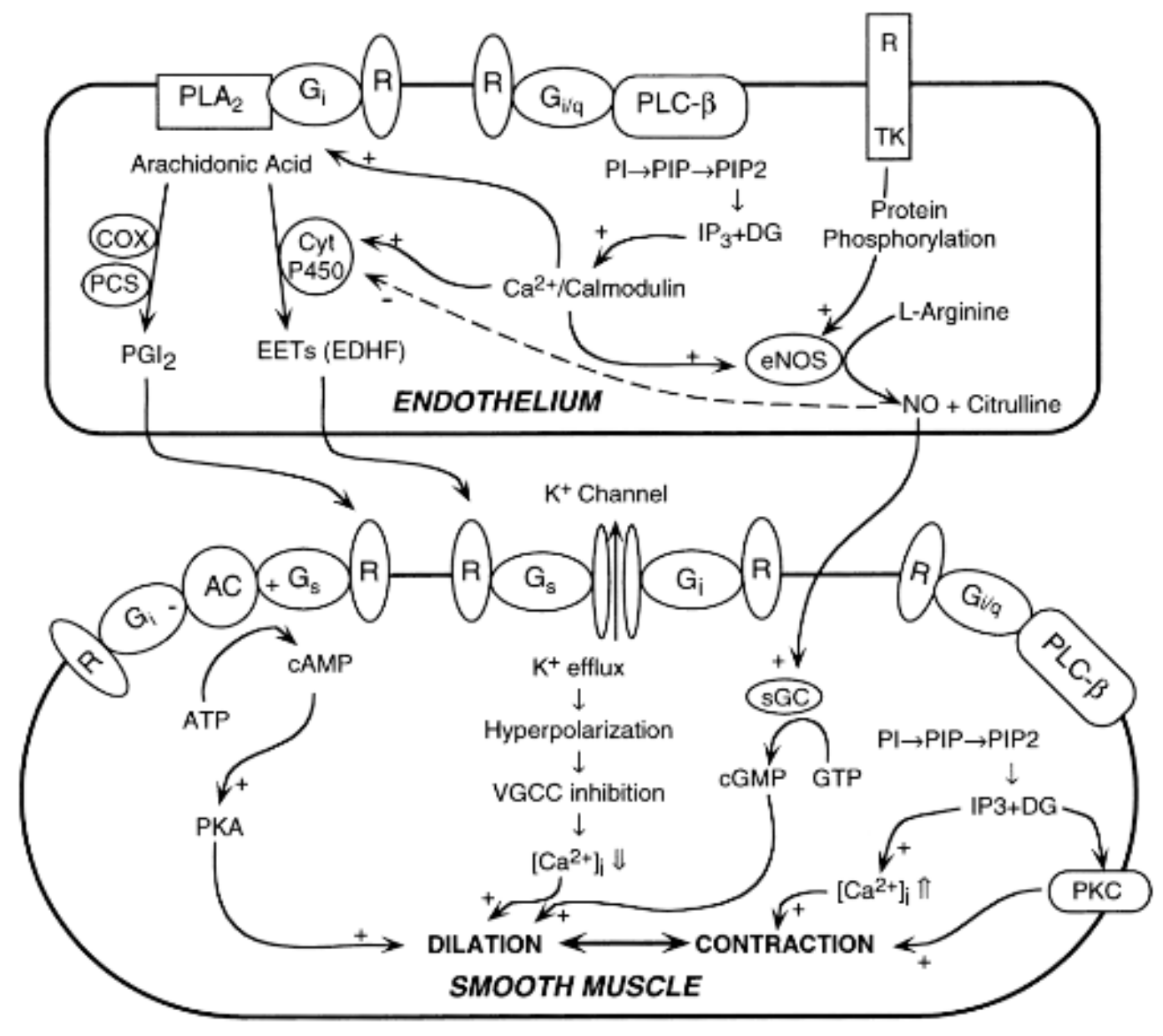




\section{Role of adenosine in coronary flow regulation}

The heart has a small anaerobic metabolic capacity and, therefore, is essentially dependent on $\mathrm{CF}$ in order to provide the heart with oxygen on a beat to beat basis. Some also say that heart function is comprised of continuous sequential episodes of transient increase in $\mathrm{CF}$, called reactive hyperemia $(\mathrm{RH})$, with the decreased flow occurring during the systole and the RH response occurring during the diastole. Additionally, during conditions such as coronary vasospasm or even exercise the myocardium is also responsive to acute periods of decreased $\mathrm{CF}$ by means of $\mathrm{RH}$. Nevertheless, as mentioned, the increase in $\mathrm{CF}$ during more aggressive conditions such as exercise or angina plays a crucial role in providing the heart with necessary oxygen. However, it is interesting to note that the myocardium is reported to only extract about $75 \%$ of the delivered oxygen at rest and that the seemingly high level of repayment during episodes of RH only provides oxygen repayment ratios of between $26-82 \%$ (129), which suffice to say that myocardium has a small oxygen extraction reserve and that the contribution of any vasodilatory factor plays a crucial role for the regulation of $\mathrm{CF}$ and the efficient oxygen supply and, hence, cardiac function. Needless to say that although the myocardial oxygen supply (in the form of blood flow or oxygen extraction) is small, the myocardial oxygen consumption can increase up to five fold when needed (43).

In 1963, Berne et al. proposed the adenosine hypothesis (7). The idea was that the myocardial oxygen supply over oxygen consumption ratio is reflected in the intracellular myocardial oxygen tension $\left(\mathrm{pO}_{2}\right)$. For example, if myocardial oxygen supply over consumption ratio decreases (as during exercise), the myocardium encounters a fall in $\mathrm{pO}_{2}$ which leads to the breakdown of adenine nucleotides (ATP, ADP, AMP) and, hence, generation of adenosine. The produced adenosine then diffuses out of the cell to act on its 
receptors on coronary arteriolar smooth muscle cells (through an endothelium-dependent and -independent manner) in order to cause vasodilation. This increase in CF delivers more oxygen to the myocardium and, thus, returns myocardial $\mathrm{pO}_{2}$ back toward the normal range (Figure 1.5). The adenosine hypothesis is also a transmitter hypothesis which suggests that adenosine transmits information regarding the status of one cell type such as cardiomyocyte to another cell type such as arteriolar smooth muscle by diffusing across the interstitial space $(43,48)$. Therefore, Berne's adenosine hypothesis suggests that adenosine coordinates the myocardial oxygen consumption to $\mathrm{CF}$ (Figure 1.5). The role of each AR subtype in the regulation of $\mathrm{CF}$ has been extensively studied.

\section{Adenosine receptors classification and characteristics}

Adenosine receptors were initially classified into $A_{1}$ and $A_{2}$ subtypes based on their potency for ligands and antagonism by methylxanthines (91). Subsequently subclassification of $A_{2}$ into $A_{2 A}$ and $A_{2 B}$ subtypes was pharmacologically based upon the high affinity $A_{2 A}$ and low affinity $A_{2 B}$ binding sites in rat brain (24). All ARs are seven transmembrane GPCR with approximately 21-28 amino acids in each transmembrane region. The $\mathrm{A}_{2 \mathrm{~A}} \mathrm{AR}$ is 409 and 410 amino acids long in human and mouse, respectively. $\mathrm{A}_{2 \mathrm{~A}} \mathrm{AR}$ is the largest of all ARs due to its extended C-terminus of no known function (121). Overall, there is relatively low level of amino acid homology between different ARs in a single species in addition to the same AR between species which may contribute to the different ARs-mediated effects observed in different species.

The N-terminus of ARs are extracellular and it was shown that all ARs other than $\mathrm{A}_{2 \mathrm{~A}} \mathrm{AR}$ have a palmitoylation site near the C-terminus (1). Furthermore, all ARs are glycosylated on their $2^{\text {nd }}$ extracellular loop (121) and although the $3^{\text {rd }}$ intracellular loop is involved in both $\mathrm{A}_{1}$ and $\mathrm{A}_{2 \mathrm{~A}} \mathrm{AR} \mathrm{G}$ protein coupling, the C-terminus is only involved in 
$\mathrm{A}_{1} \mathrm{AR} G$ protein coupling (151). It was also reported that the $\mathrm{A}_{2 \mathrm{~A}} \mathrm{AR}$ phosphorylation of intracellular loop is involved in this AR desensitization (118). Currently, all four ARs are cloned and their expressions in various tissues have been extensively studied.

The $\mathrm{A}_{2 \mathrm{~A}} \mathrm{AR}$ gene has been localized to chromosome $22 \mathrm{q} 11.23(27,92)$ and chromosome 10 in human and mouse, respectively (162). However, the $A_{2 B} A R$ gene has been localized to chromosome 17p12-11.2 (69) chromosome 11 in human and mouse, respectively (162). $\mathrm{A}_{2 \mathrm{~A}} \mathrm{AR}$ was the first $\mathrm{AR}$ genetically modified in a murine model (89). The $\mathrm{A}_{2 \mathrm{~A}} \mathrm{AR}$ knockout (KO) mice were developed in three different genetic backgrounds of CD1, congenic C57B L/6, and pure 129-Steel $(17-18,89)$ while $\mathrm{A}_{2 \mathrm{~B}} \mathrm{AR}$ has been recently developed only in C57BL/6 background. $\mathrm{A}_{2 \mathrm{~A}} \mathrm{KO}$ animals demonstrated several central nervous system disturbances such as decreased exploratory activity, increased aggressiveness and hypoalgesia (89). Furthermore, $\mathrm{A}_{2 \mathrm{~A}} \mathrm{KO}$ mice with $\mathrm{CD} 1$ genetic background were demonstrated to have increased blood pressure, heart rate, and platelet aggregation (89) while an $\mathrm{A}_{2 \mathrm{~A}} \mathrm{KO}$ mice on either a mixed 129Steel-C57BL/6 or congenic C57BL/6 genetic background did not show any change in blood pressure $(17,26)$. While there are relatively a large number of studies on $\mathrm{A}_{2 \mathrm{~A}} \mathrm{KO}$, there are not many studies using $\mathrm{A}_{2 \mathrm{~B}} \mathrm{KO}$ mice and, therefore, a better understanding of its functional effects or compensatory mechanisms due to its genetic modification still remains to be fully elucidated.

$\boldsymbol{A}_{2}$ ARs: The presence of both $\mathrm{A}_{2 \mathrm{~A}}$ and $\mathrm{A}_{2 \mathrm{~B}} \mathrm{ARs}$ on coronary endothelial and smooth muscle cells and the pivotal vasoregulatory role of adenosine in human CA is well established $(37-38,113,130,133)$. The involvement of $\mathrm{A}_{2 \mathrm{~A}} \mathrm{AR}$ in the regulation of $\mathrm{CF}$ in various other species has been also broadly reported $(11,37-38,74,106,130,133$, 137, 142, 145, 167). Previous studies further suggest that metabolic vasodilatory factors 
such as adenosine are the primary mediators responsible for the $\mathrm{CF}$ regulation during $\mathrm{RH}$ $(21,63,114-115)$. In vivo studies in dogs showed a role for $\mathrm{A}_{2 \mathrm{~A}} \mathrm{AR}$ in $\mathrm{CF}$ regulation during RH (32), which further confirms the physiological role of adenosine. Zatta et al. also confirmed this finding by using pharmacological approaches $(11,167)$. Furthermore, it is proposed that $\mathrm{A}_{2 \mathrm{~A}} \mathrm{AR}$ contributes to the coronary circulation basal tone since deletion of $\mathrm{A}_{2 \mathrm{~A}} \mathrm{AR}$ and application of $\mathrm{SCH} 58261\left(\mathrm{~A}_{2 \mathrm{~A}}\right.$ selective antagonist) diminished the baseline CF compared to WT hearts $(137,145)$.

Due to its lower affinity for adenosine, $A_{2 B} A R$ is activated in conditions where a significant increase in adenosine levels is observed, such as in ischemia (48). Also, a previous study showed that $\mathrm{A}_{2 \mathrm{~B}} \mathrm{AR}$ may not play a role in basal tone regulation of $\mathrm{CF}$ since targeted deletion of $\mathrm{A}_{2 \mathrm{~B}} \mathrm{AR}$ had no effect on the baseline CF (137). Additionally, Tune et al. suggested no role for $\mathrm{A}_{2 \mathrm{~B}} \mathrm{AR}$ in $\mathrm{RH}$ by means of indirect measures such as using non-selective antagonist (11). Nevertheless, $A_{2 B} A R$ is shown to be involved in the regulation of $\mathrm{CF}$, albeit may be with a lesser contribution compared to $\mathrm{A}_{2 \mathrm{~A}} \mathrm{AR}(13,106$, 137, 142). Furthermore, recent studies suggested an interrelationship between $A_{2 A}$ and $\mathrm{A}_{2 \mathrm{~B}} \mathrm{ARs}$ subtypes since one compensates for the down-regulation/deletion of the other $(137,145)$ through their up-regulation in coronary arterioles. In fact the involvement of $\mathrm{A}_{2 \mathrm{~A}}$ and $\mathrm{A}_{2 \mathrm{~B}} \mathrm{ARs}$ and their down- or up-regulation is reported in many pathophysiological conditions $(2,4,41,75)$. Regardless of this relationship, the differential expression of ARs is shown to contribute to functional heterogeneity of human endothelial cells (45) and the impairment of adenosine-related signaling contributes to the pathophysiology of congestive heart failure (2). By benefiting from gene-modified models and pharmacological approaches and by using selective adenosine analogs, we were allowed 
to better assess the role of $\mathrm{A}_{2} \mathrm{ARs}$ in the regulation of $\mathrm{CF}$ and, therefore, to better understand the heterogeneity of $\mathrm{CF}$ in relation to $\mathrm{A}_{2} \mathrm{ARs}$ responses.

$\boldsymbol{A}_{\boldsymbol{I}} \boldsymbol{A R}$ : There are previous reports from our laboratory suggesting that $\mathrm{A}_{1} \mathrm{AR}$ negatively modulates the role of $\mathrm{A}_{2 \mathrm{~A}} \mathrm{ARs}$ and probably $\mathrm{A}_{2 \mathrm{~B}} \mathrm{ARs}$ in $\mathrm{CF}$ regulation (141, 144). The presence of only $A_{2 A} A R s$ and $A_{2 B} A R s$ on coronary endothelial cells may also indirectly support this finding (113). Additionally, it was recently reported that in Ossabaw swine $\mathrm{A}_{1} \mathrm{AR}$ antagonism by DPCPX positively regulated basal CF. However, although $\mathrm{A}_{1} \mathrm{AR}$ may not play a major role in $\mathrm{CF}$ regulation, it has been shown that this receptor mediates negative chronotropic effects which may indirectly affect the $\mathrm{CF}$ in conditions where adenosine concentration is elevated enough to induce the chronotropic effect of this AR subtype. Nevertheless, $A_{1}$ ARs are known to protect the heart from ischemia-reperfusion $(107,161,168)$ and coronary atherosclerosis (preliminary data from our laboratory (146)).

$\boldsymbol{A}_{3} \boldsymbol{A R}$ : Zhao et al. showed that high concentrations of $\mathrm{A}_{3} \mathrm{AR}$ agonist, $\mathrm{Cl}-$ IBMECA, induced coronary vasodilation which was further blocked by $\mathrm{A}_{2 \mathrm{~A}} \mathrm{AR}$ antagonism (171). However, $\mathrm{A}_{3} \mathrm{AR}$ targeted deletion increased the $\mathrm{A}_{2 \mathrm{~A}} \mathrm{AR}$-mediated response. This finding may suggest that $\mathrm{A}_{3} \mathrm{AR}$ also participate in $\mathrm{CF}$ regulation of isolated murine hearts via negative modulation of $\mathrm{A}_{2 \mathrm{~A}} \mathrm{AR}$-mediated coronary vasodilation (141). Additionally, single-nucleotide polymorphism (SNP) of I248L in $\mathrm{A}_{3} \mathrm{AR}$ gene is shown to be associated with coronary heart disease (120). Further studies are required to better understand the role of $\mathrm{A}_{3} \mathrm{AR}$ in $\mathrm{CF}$ regulation and responses. 
Figure 1.5 Berne's adenosine hypothesis. Scheme adapted from Feigl et al. (43)

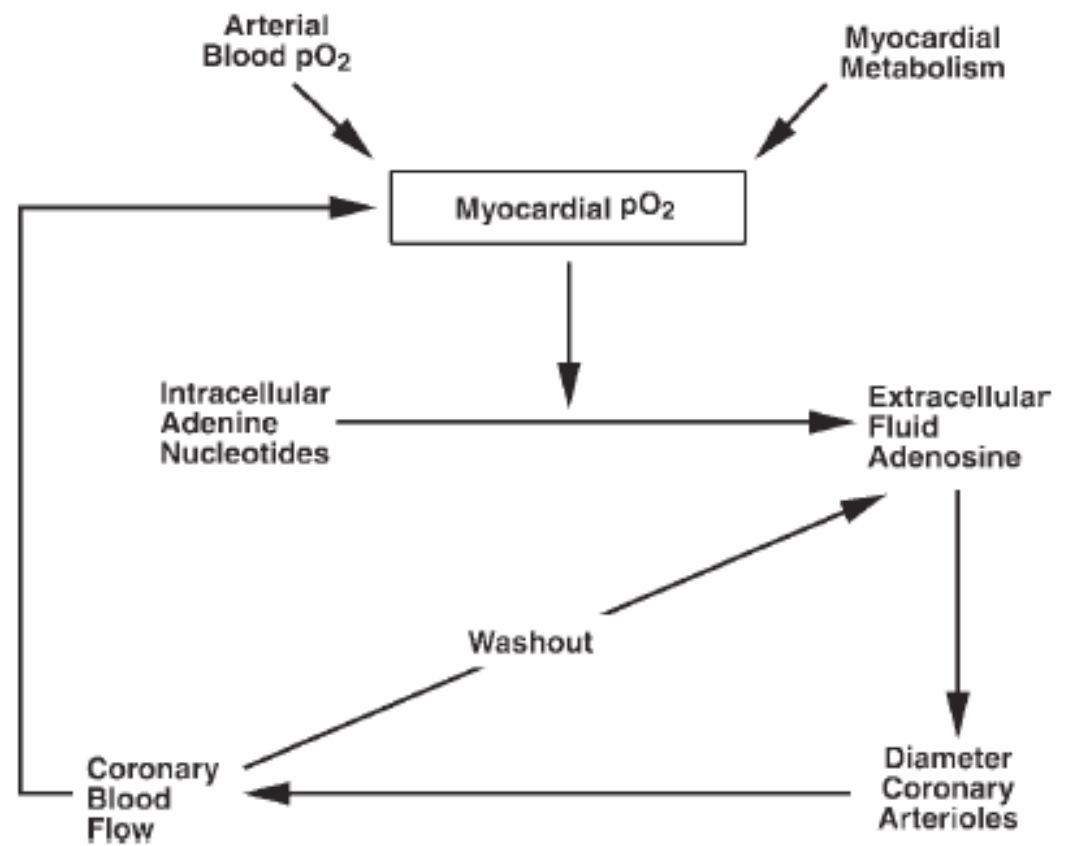




\section{Classically known signaling of adenosine receptors}

As mentioned, each AR has its own pharmacological profile. Adenosine at its basal concentration is sufficient to activate $A_{1}, A_{2 A}$, and $A_{3} A R s$. However, due to its low affinity for adenosine, $\mathrm{A}_{2 \mathrm{~B}} \mathrm{ARs}$ are activated in conditions where significant high levels of adenosine are produced, such as in pathophysiological conditions. It is well established that $A_{1}$ and $A_{3} A R s$ are associated with $G_{i}$ proteins while $A_{2 A}$ and $A_{2 B} A R s$ are coupled to $\mathrm{G}_{\mathrm{s}}$ proteins. The $\mathrm{A}_{1}$ and $\mathrm{A}_{3} \mathrm{ARs}$ signal through $\mathrm{G}_{\mathrm{i} / \mathrm{o}}$ proteins and its activation leads to an inhibition of adenylyl cyclase (AC) which causes a lowering of cyclic AMP (cAMP) levels. The $A_{2 A}$ and $A_{2 B} A R s$ signal through the Gs pathway and its activation leads to stimulation of AC resulting in increased production of cAMP. Classically, ARs were thought to induce their effects through inhibition $\left(\mathrm{G}_{\mathrm{i}}\right)$ or stimulation $\left(\mathrm{G}_{\mathrm{s}}\right)$ of adenylyl cyclase. However, it is becoming more and more evident that these receptors also activate other pathways such as phospholipase C (PLC), mitogen-activated protein kinase (MAPK), etc. In fact, signaling through the $\mathrm{A}_{1} \mathrm{AR}$ can also lead to activation of $\mathrm{IP}_{3} / \mathrm{DAG}$ through the PLC pathway $(68,143)$. Additionally, the $A_{2 B}$ receptor signals through $G_{s / q}$ and its activation can either result in increased cAMP or $\mathrm{IP}_{3} / \mathrm{DAG}$ and $\mathrm{Ca}^{2+}$ levels. Furthermore, ARs are now shown to be associated with the $\mathrm{K}^{+}$channels, production of reactive oxygen species (ROS) and activation of the arachidonic pathway $(34,50,59$, $111,137)$.

\section{Role of $\mathrm{K}^{+}$channels in $A_{2 A} A R$-mediated coronary flow regulation}

$\mathrm{K}^{+}$channels play an essential role in determining the cell membrane potential and regulating the contractile tone of arterial smooth muscle cells through controlling the $\mathrm{Ca}^{2+}$ entry via voltage-dependent $\mathrm{Ca}^{2+}$ channels and, thereby, the contractility (67). There

are four types of $\mathrm{K}^{+}$channels on $\mathrm{CA}$ smooth muscle and endothelial cells: voltage- 
dependent $\mathrm{K}^{+}\left(\mathrm{K}_{\mathrm{V}}\right), \mathrm{Ca}^{2+}$ dependent $\mathrm{K}^{+}(\mathrm{BKCa})$, ATP-dependent $\mathrm{K}^{+}\left(\mathrm{K}_{\mathrm{ATP}}\right)$, and inward rectifier $\mathrm{K}^{+}$(Kir) channels. $\mathrm{K}_{\mathrm{ATP}}$ channels are shown to be present on isolated coronary artery cells $(51,140)$, in addition to $\mathrm{K}_{\mathrm{V}}$ channels which are known to be expressed on coronary arteries $(33,66,140,156,166)$. Additionally, BKCa channels are known to be abundantly expressed on coronary smooth muscle cells and contribute to CA vasodilation in different species $(15,64,102)$, in addition, to Kir channels which are reported to be present on both coronary smooth muscle and endothelial cells $(119,126,140,157,166)$.

It is worth mentioning that $\mathrm{K}^{+}$was suggested to be the EDHF in various vascular beds (39-40). Additionally, in general, $\mathrm{K}^{+}$channels have been suggested to be involved in $\mathrm{A}_{2 \mathrm{~A}}$ and $\mathrm{A}_{2 \mathrm{~B}} \mathrm{ARs}$-mediated hyperpolarization of $\mathrm{CA}(55-56,74,109,112,137,170)$ and in adenosine's role in potentiating flow-induced CA vasodilation (84). Coronary arteriolar smooth muscle $\mathrm{K}_{\mathrm{ATP}}$ channels are tonically active under physiological conditions. Indeed, in humans as well as in different animal species, application of glibenclamide, a $\mathrm{K}_{\text {ATP }}$ channel blocker, resulted in a decrease in resting blood flow (42, 124-125, 137). Additionally, a primary role for $\mathrm{K}_{\mathrm{ATP}}$ channels in mediating the sustained dilation of CA during RH was suggested (167).

Adenosine is reported to activate $\mathrm{K}_{\mathrm{ATP}}$ channels in rabbit isolated CA smooth muscle cells (140) and in the $\mathrm{A}_{2 \mathrm{~A}}$-induced effect in $\mathrm{RH}(11,167)$. Additionally, a recent study proposed that the decrease in CF produced by intracoronary glibenclamide may cause metabolic changes of ischemia including the release of adenosine $(35,132)$. This is an important observation, since it indicates that blockade of the endogenous vasodilator system associated with $\mathrm{K}_{\mathrm{ATP}}$ channel activity can cause coronary vasoconstriction sufficient to result in myocardial ischemia (132). Adenosine-mediated activation of $\mathrm{K}_{\mathrm{ATP}}$ channels may be indirectly through release of some other mediators such as $\mathrm{H}_{2} \mathrm{O}_{2}$ (please 
see the role of $\mathrm{H}_{2} \mathrm{O}_{2}$ in $\mathrm{A}_{2 \mathrm{~A}} \mathrm{AR}$-mediated $\mathrm{CF}$ regulation section)(50). A study reported that the effect of adenosine on endothelial $\mathrm{K}_{\mathrm{ATP}}$ channels may be mediated via pertussis toxic-sensitive G proteins and not through the release of NO and cGMP production, whereas activation of smooth muscle cell $\mathrm{K}_{\mathrm{ATP}}$ channels may not involve $\mathrm{G}$ proteins (59). Moreover, the enhanced responsiveness to adenosine at lower CA intraluminal pressure was suggested to be due to increased smooth muscle cell $\mathrm{K}_{\mathrm{ATP}}$ channels activity (169). In addition to the $\mathrm{A}_{2} \mathrm{AR}$-mediated pathway, one study suggested that adenosine also activates $K_{\text {ATP }}$ currents in single CA smooth muscle cells via $A_{1} A R s$ (25). Nevertheless, the signaling pathway due to the activation of endothelial $\mathrm{K}_{\mathrm{ATP}}$ channels is yet to be fully explored.

To date no patch clamp study has demonstrated the effect of adenosine on $\mathrm{K}_{\mathrm{V}}$ currents in CA smooth muscle cells. However, in vivo studies have shown that 4aminopyridine, $\mathrm{K}_{\mathrm{V}}$ channel blocker, inhibited $\mathrm{CA}$ vasodilation induced by adenosine (11, 32, 56-58). Previous studies on CA smooth muscle cells also indicate the involvement of PKC and PKA in the $K_{V}$ channel-mediated pathway $(138,140)$, which renders the question whether adenosine induces the activation of $\mathrm{K}_{\mathrm{V}}$ channels through the PKC pathway.

\section{Role of $\mathrm{H}_{2} \mathrm{O}_{2}$ in $\mathrm{A}_{2 A} A R$-mediated coronary flow regulation}

$\mathrm{H}_{2} \mathrm{O}_{2}$ is suggested to act as EDHF in humans and mice $(95,97,163)$. Additionally, it was reported that $\mathrm{H}_{2} \mathrm{O}_{2}$ induces $\mathrm{CA}$ vasodilation through both endothelium-dependent and -independent manners (147). Recent reports have established the contribution of $\mathrm{H}_{2} \mathrm{O}_{2}$ in flow-induced dilation of isolated human CA (101) and in reactive dilatation of rat isolated coronary arterioles (79). Yada et al. proposed that $\mathrm{H}_{2} \mathrm{O}_{2}$ (as an EDHF in vivo) plays an important role in CA autoregulation in cooperation with 
adenosine and NO (163). However, so far there are no reports showing the relationship between $\mathrm{H}_{2} \mathrm{O}_{2}$ and adenosine-mediated coronary vasodilation, which lead to the basis of our study.

It is worth mentioning that Berne's adenosine hypothesis suggests that increases in myocardial oxygen consumption decrease myocardial oxygen tension which leads to the stimulation of the release of adenosine from cardiomyocytes (152), where $\mathrm{A}_{2 \mathrm{~A}} \mathrm{ARs}$ have also been found to be expressed in both human and mouse (16, 93). Adenosine induces CA dilatation through activation of sites on cardiomyocytes in addition to the arteriole vascular bed itself (148). Furthermore, as mentioned, a role for $\mathrm{H}_{2} \mathrm{O}_{2}$ in metabolic vasodilation has already been proposed (164) and Chilian et al. suggested that $\mathrm{H}_{2} \mathrm{O}_{2}$ production increases in proportion to cardiac metabolism in order to couple the coronary blood flow to myocardial oxygen tension (131). What is interesting to appreciate is that both $\mathrm{H}_{2} \mathrm{O}_{2}$ and adenosine are released from cardiomyocytes and that they may modulate the vascular tone through the cardiac myocyte (72). Therefore, myocardium may be partly the source of both adenosine and $\mathrm{H}_{2} \mathrm{O}_{2}$ released for the regulation of CF. Our study is based on such similarities between adenosine and $\mathrm{H}_{2} \mathrm{O}_{2}$ (please also refer to chapter 4).

\section{Relationship between adrenoceptors $(A D R)$ and $A_{2} A R s$ in coronary flow regulation}

Endogenous adenosine was reported to affect the norepinephrine release from sympathetic nerve endings (127). The $\mathrm{A}_{2 \mathrm{~A}} \mathrm{AR}$-mediated facilitation of norepinephrine release was also suggested to require activation of the PKC and PKA pathways (49) which itself is proposed as an adenosine signaling pathway. It was reported that $\alpha$ ADRmediated coronary vasoconstriction during exercise limits coronary perfusion in impaired endothelial function situations (70). DeFily et al. further added to this finding by showing 
that, even in normal conditions, stimulation of $\alpha \mathrm{ADR}$-induced vasoconstriction is masked by autoregulatory control, by means of NO release and endogenous adenosine (28). Furthermore, it was demonstrated that coronary RH responses due to adenosine are blocked by $\alpha$ ADRs when NO synthesis is interrupted (14). On the other hand, the cardioprotective effect of carvedilol, a $\beta$ ADR blocker, was shown to be through an adenosine-dependent mechanism (3). Additionally, it was demonstrated that $\beta$ ADRmediated inotropic responses were attenuated by adenosine (134). Therefore, overall there is some evidence on similarities between ADR and AR cardiovascular effects and signaling. However, there are no studies on the interaction or cross talk of ARs and ADRs in the regulation of $\mathrm{CF}$ which was the basis of our new study (Please see our appendix A).

\section{Clinical applications}

Adenosine and its agonist are currently being used in clinical settings; The vasoregulatory properties of $\mathrm{A}_{2 \mathrm{~A}} \mathrm{ARs}$ are used clinically in humans for the diagnosis of coronary artery disease through the use of adenosine (Adenoscan) as a substitute for exercise stress testing for people who can't exercise in myocardial perfusion imaging (12). The use of Adenoscan has its own limitations due to its blocking effect on AV conduction [due to activation of $\mathrm{A}_{1} \mathrm{ARs}(10,12)$ ] and inducing bronchospasm [probably due to activation of $A_{1}, A_{3}$ or $\left.A_{2 B} A R s(47,123)\right]$. However, these side effects may be alleviated by the development of more $\mathrm{A}_{2} \mathrm{ARs}$ subtype selective agonists. A new $\mathrm{A}_{2 \mathrm{~A}} \mathrm{AR}$ selective agonist called Regadenoson (Lexiscan ${ }^{\circledR}$ ) has been developed and approved by FDA which is being used clinically in myocardial perfusion imaging. Additionally, in many cardiovascular diseases such as coronary atherosclerosis, angina, and hypertension, an attenuated vascular response to adenosine has been demonstrated where functional 
disturbance of smooth muscle or endothelial cells may be the underlying cause. Therefore, it is important to better understand adenosine's role in the regulation of CF, its mechanism of action, and its interplay with other AR receptors, and/or its interaction with the ADRs. 


\section{Project Summary}

Adenosine plays an important role in coronary flow regulation in physiological and pathological conditions where AR expression modification may occur. Therefore, the purpose of this investigation was to better understand the individual role and contribution of $\mathrm{A}_{2} \mathrm{ARs}$ in the regulation of coronary flow and their mechanism of action during their exogenous and endogenous activation. In addition to better understand the heterogeneity of CF responses by ARs, elucidation of ARs' role in CF regulation would enable us to develop therapies with less unwanted side effects or new enhanced medications for the diagnosis and/or treatment of cardiovascular disorders. With this purpose in mind, the following aims were developed:

Specific Aim 1: Elucidation of the role of $A_{2} A R s$ in the regulation of coronary flow Specific Aim 2: Identification of $A_{2}$ ARs signaling pathways in coronary flow regulation

Specific Aim 3: Characterize the role of $A_{2} A R s$ in coronary reactive hyperemia Specific Aim 4: Identify the role of $\mathrm{H2O2}$ in $\mathrm{A}_{2}$ ARs' signaling pathway during reactive hyperemia 


\section{References}

1. Armstrong JM, Chen JF, Schwarzschild MA, Apasov S, Smith PT, Caldwell C, Chen P, Figler H, Sullivan G, Fink S, Linden J, and Sitkovsky M. Gene dose effect reveals no Gs-coupled A2A adenosine receptor reserve in murine T-lymphocytes: studies of cells from A2A-receptor-gene-deficient mice. Biochem J 354: 123-130, 2001.

2. Asakura M, Asanuma H, Kim J, Liao Y, Nakamaru K, Fujita M, Komamura K, Isomura T, Furukawa H, Tomoike H, and Kitakaze M. Impact of adenosine receptor signaling and metabolism on pathophysiology in patients with chronic heart failure. Hypertens Res 30: 781-787, 2007.

3. Asanuma H, Minamino T, Sanada S, Takashima S, Ogita H, Ogai A, Asakura M, Liao Y, Asano Y, Shintani Y, Kim J, Shinozaki Y, Mori H, Node K, Kitamura S, Tomoike H, Hori M, and Kitakaze M. Beta-adrenoceptor blocker carvedilol provides cardioprotection via an adenosine-dependent mechanism in ischemic canine hearts. Circulation 109: 2773-2779, 2004.

4. Ashton KJ, Nilsson U, Willems L, Holmgren K, and Headrick JP. Effects of aging and ischemia on adenosine receptor transcription in mouse myocardium. Biochem Biophys Res Commun 312: 367-372, 2003.

5. Bassenge E, Kucharczyk M, Holtz J, and Stoian D. Treadmill exercise in dogs under -adrenergic blockade: adaptation of coronary and systemic hemodynamics. Pflugers Arch 332: 40-55, 1972.

6. Beny JL and Schaad O. An evaluation of potassium ions as endothelium-derived hyperpolarizing factor in porcine coronary arteries. Br J Pharmacol 131: 965-973, 2000.

7. Berne RM. Cardiac nucleotides in hypoxia: possible role in regulation of coronary blood flow. Am J Physiol 204: 317-322, 1963. 
8. Berne RM. The role of adenosine in the regulation of coronary blood flow. Circ Res 47: 807-813, 1980.

9. Bernstein RD, Ochoa FY, Xu X, Forfia P, Shen W, Thompson CI, and Hintze

TH. Function and production of nitric oxide in the coronary circulation of the conscious dog during exercise. Circ Res 79: 840-848, 1996.

10. Bertolet BD, Belardinelli L, Franco EA, Nichols WW, Kerensky RA, and Hill JA. Selective attenuation by N-0861 (N6-endonorboran-2-yl-9-methyladenine) of cardiac A1 adenosine receptor-mediated effects in humans. Circulation 93: 1871-1876, 1996.

11. Berwick ZC, Payne GA, Lynch B, Dick GM, Sturek M, and Tune JD. Contribution of adenosine $\mathrm{A}(2 \mathrm{~A})$ and $\mathrm{A}(2 \mathrm{~B})$ receptors to ischemic coronary dilation: role of K(V) and K(ATP) channels. Microcirculation 17: 600-607.

12. Botvinick EH. Current methods of pharmacologic stress testing and the potential advantages of new agents. J Nucl Med Technol 37: 14-25, 2009.

13. Brackett LE and Daly JW. Functional characterization of the A2b adenosine receptor in NIH 3 T3 fibroblasts. Biochem Pharmacol 47: 801-814, 1994.

14. Buus NH, Bottcher M, Hermansen F, Sander M, Nielsen TT, and Mulvany MJ. Influence of nitric oxide synthase and adrenergic inhibition on adenosine-induced myocardial hyperemia. Circulation 104: 2305-2310, 2001.

15. Bychkov R, Burnham MP, Richards GR, Edwards G, Weston AH, Feletou M, and Vanhoutte PM. Characterization of a charybdotoxin-sensitive intermediate conductance $\mathrm{Ca} 2+$-activated $\mathrm{K}+$ channel in porcine coronary endothelium: relevance to EDHF. Br J Pharmacol 137: 1346-1354, 2002. 
16. Chandrasekera PC, McIntosh VJ, Cao FX, and Lasley RD. Differential effects of adenosine A2a and A2b receptors on cardiac contractility. Am J Physiol Heart Circ Physiol 299: H2082-2089, 2010.

17. Chen JF, Huang Z, Ma J, Zhu J, Moratalla R, Standaert D, Moskowitz MA, Fink JS, and Schwarzschild MA. A(2A) adenosine receptor deficiency attenuates brain injury induced by transient focal ischemia in mice. J Neurosci 19: 9192-9200, 1999.

18. Chen JF, Moratalla R, Impagnatiello F, Grandy DK, Cuellar B, Rubinstein M, Beilstein MA, Hackett E, Fink JS, Low MJ, Ongini E, and Schwarzschild MA. The role of the $\mathrm{D}(2)$ dopamine receptor $(\mathrm{D}(2) \mathrm{R})$ in $\mathrm{A}(2 \mathrm{~A})$ adenosine receptor $(\mathrm{A}(2 \mathrm{~A}) \mathrm{R})$ mediated behavioral and cellular responses as revealed by $\mathrm{A}(2 \mathrm{~A})$ and $\mathrm{D}(2)$ receptor knockout mice. Proc Natl Acad Sci U S A 98: 1970-1975, 2001.

19. Chilian WM, Kuo L, DeFily DV, Jones CJ, and Davis MJ. Endothelial regulation of coronary microvascular tone under physiological and pathophysiological conditions. Eur Heart J 14 Suppl I: 55-59, 1993.

20. Cocks TM and Angus JA. Endothelium-dependent relaxation of coronary arteries by noradrenaline and serotonin. Nature 305: 627-630, 1983.

21. Coffman JD and Gregg DE. Reactive hyperemia characteristics of the myocardium. Am J Physiol 199: 1143-1149, 1960.

22. Cole WC, Chen TT, and Clement-Chomienne O. Myogenic regulation of arterial diameter: role of potassium channels with a focus on delayed rectifier potassium current. Can J Physiol Pharmacol 83: 755-765, 2005.

23. Cole WC, Plane F, and Johnson R. Role of Kv1 channels in control of arterial myogenic reactivity to intraluminal pressure. Circ Res 97: e1, 2005. 
24. Daly JW and Padgett WL. Agonist activity of 2- and 5'-substituted adenosine analogs and their N6-cycloalkyl derivatives at A1- and A2-adenosine receptors coupled to adenylate cyclase. Biochem Pharmacol 43: 1089-1093, 1992.

25. Dart C and Standen NB. Adenosine-activated potassium current in smooth muscle cells isolated from the pig coronary artery. J Physiol 471: 767-786, 1993.

26. Day YJ, Huang L, McDuffie MJ, Rosin DL, Ye H, Chen JF, Schwarzschild MA, Fink JS, Linden J, and Okusa MD. Renal protection from ischemia mediated by A2A adenosine receptors on bone marrow-derived cells. J Clin Invest 112: 883-891, 2003.

27. Deckert J, Nothen MM, Bryant SP, Schuffenhauer S, Schofield PR, Spurr NK, and Propping P. Mapping of the human adenosine A2a receptor gene: relationship to potential schizophrenia loci on chromosome $22 \mathrm{q}$ and exclusion from the CATCH 22 region. Hum Genet 99: 326-328, 1997.

28. DeFily DV, Patterson JL, and Chilian WM. Endogenous adenosine modulates alpha 2- but not alpha 1-adrenergic constriction of coronary arterioles. Am J Physiol 268: H2487-2494, 1995.

29. Dessy C, Matsuda N, Hulvershorn J, Sougnez CL, Sellke FW, and Morgan KG. Evidence for involvement of the PKC-alpha isoform in myogenic contractions of the coronary microcirculation. Am J Physiol Heart Circ Physiol 279: H916-923, 2000.

30. Deussen A, Lloyd HG, and Schrader J. Contribution of Sadenosylhomocysteine to cardiac adenosine formation. J Mol Cell Cardiol 21: 773-782, 1989.

31. DiCarlo SE, Blair RW, Bishop VS, and Stone HL. Role of beta 2-adrenergic receptors on coronary resistance during exercise. J Appl Physiol 64: 2287-2293, 1988. 
32. Dick GM, Bratz IN, Borbouse L, Payne GA, Dincer UD, Knudson JD, Rogers

PA, and Tune JD. Voltage-dependent $\mathrm{K}+$ channels regulate the duration of reactive hyperemia in the canine coronary circulation. Am J Physiol Heart Circ Physiol 294: H2371-2381, 2008.

33. Dick GM and Tune JD. Role of potassium channels in coronary vasodilation. Exp Biol Med (Maywood) 235: 10-22.

34. Donoso MV, Lopez R, Miranda R, Briones R, and Huidobro-Toro JP. A2B adenosine receptor mediates human chorionic vasoconstriction and signals through arachidonic acid cascade. Am J Physiol Heart Circ Physiol 288: H2439-2449, 2005.

35. Duncker DJ and Bache RJ. Regulation of coronary blood flow during exercise. Physiol Rev 88: 1009-1086, 2008.

36. Duncker DJ, van Zon NS, Pavek TJ, Herrlinger SK, and Bache RJ. Endogenous adenosine mediates coronary vasodilation during exercise after K(ATP)+ channel blockade. J Clin Invest 95: 285-295, 1995.

37. Edlund A, Conradsson T, and Sollevi A. A role for adenosine in coronary vasoregulation in man. Effects of theophylline and enprofylline. Clin Physiol 15: 623636, 1995.

38. Edlund A and Sollevi A. Theophylline increases coronary vascular tone in humans: evidence for a role of endogenous adenosine in flow regulation. Acta Physiol Scand 155: 303-311, 1995.

39. Edwards G, Dora KA, Gardener MJ, Garland CJ, and Weston AH. K+ is an endothelium-derived hyperpolarizing factor in rat arteries. Nature 396: 269-272, 1998.

40. Edwards G and Weston AH. Endothelium-derived hyperpolarizing factor--a critical appraisal. Prog Drug Res 50: 107-133, 1998. 
41. Eltzschig HK, Ibla JC, Furuta GT, Leonard MO, Jacobson KA, Enjyoji K, Robson SC, and Colgan SP. Coordinated adenine nucleotide phosphohydrolysis and nucleoside signaling in posthypoxic endothelium: role of ectonucleotidases and adenosine A2B receptors. J Exp Med 198: 783-796, 2003.

42. Farouque HM, Worthley SG, Meredith IT, Skyrme-Jones RA, and Zhang MJ. Effect of ATP-sensitive potassium channel inhibition on resting coronary vascular responses in humans. Circ Res 90: 231-236, 2002.

43. Feigl EO. Berne's adenosine hypothesis of coronary blood flow control. Am J Physiol Heart Circ Physiol 287: H1891-1894, 2004.

44. Feigl EO. Coronary physiology. Physiol Rev 63: 1-205, 1983.

45. Feoktistov I, Goldstein AE, Ryzhov S, Zeng D, Belardinelli L, VoynoYasenetskaya T, and Biaggioni I. Differential expression of adenosine receptors in human endothelial cells: role of A2B receptors in angiogenic factor regulation. Circ Res 90: 531-538, 2002.

46. Fisslthaler B, Popp R, Kiss L, Potente M, Harder DR, Fleming I, and Busse R. Cytochrome P450 2C is an EDHF synthase in coronary arteries. Nature 401: 493-497, 1999.

47. Forsythe P, McGarvey LP, Heaney LG, MacMahon J, and Ennis M. Adenosine induces histamine release from human bronchoalveolar lavage mast cells. Clin Sci (Lond) 96: 349-355, 1999.

48. Fredholm BB. Adenosine, an endogenous distress signal, modulates tissue damage and repair. Cell Death Differ 14: 1315-1323, 2007. 
49. Fresco P, Diniz C, and Goncalves J. Facilitation of noradrenaline release by activation of adenosine $\mathrm{A}(2 \mathrm{~A})$ receptors triggers both phospholipase $\mathrm{C}$ and adenylate cyclase pathways in rat tail artery. Cardiovasc Res 63: 739-746, 2004.

50. Gebremedhin D, Weinberger B, Lourim D, and Harder DR. Adenosine can mediate its actions through generation of reactive oxygen species. J Cereb Blood Flow Metab 30: 1777-1790.

51. Glavind-Kristensen M, Matchkov V, Hansen VB, Forman A, Nilsson H, and Aalkjaer C. KATP-channel-induced vasodilation is modulated by the Na,K-pump activity in rabbit coronary small arteries. Br J Pharmacol 143: 872-880, 2004.

52. Gregg DE, Khouri EM, Donald DE, Lowensohn HS, and Pasyk S. Coronary circulation in the conscious dog with cardiac neural ablation. Circ Res 31: 129-144, 1972.

53. Groves P, Kurz S, Just H, and Drexler H. Role of endogenous bradykinin in human coronary vasomotor control. Circulation 92: 3424-3430, 1995.

54. Gschwend S, Henning RH, de Zeeuw D, and Buikema H. Coronary myogenic constriction antagonizes EDHF-mediated dilation: role of $\mathrm{KCa}$ channels. Hypertension 41: 912-918, 2003.

55. Haddy FJ, Vanhoutte PM, and Feletou M. Role of potassium in regulating blood flow and blood pressure. Am J Physiol Regul Integr Comp Physiol 290: R546-552, 2006.

56. Heaps CL and Bowles DK. Gender-specific $\mathrm{K}(+)$-channel contribution to adenosine-induced relaxation in coronary arterioles. J Appl Physiol 92: 550-558, 2002.

57. Heaps CL, Jeffery EC, Laine GA, Price EM, and Bowles DK. Effects of exercise training and hypercholesterolemia on adenosine activation of voltage-dependent K+ channels in coronary arterioles. J Appl Physiol 105: 1761-1771, 2008. 
58. Heaps CL, Tharp DL, and Bowles DK. Hypercholesterolemia abolishes voltage-dependent $\mathrm{K}+$ channel contribution to adenosine-mediated relaxation in porcine coronary arterioles. Am J Physiol Heart Circ Physiol 288: H568-576, 2005.

59. Hein TW and Kuo L. cAMP-independent dilation of coronary arterioles to adenosine : role of nitric oxide, G proteins, and K(ATP) channels. Circ Res 85: 634-642, 1999.

60. Heyndrickx GR. Alpha-adrenergic receptors and coronary blood vessels. Bibl Cardiol: 161-168, 1984.

61. Heyndrickx GR, Pannier JL, Muylaert P, Mabilde C, and Leusen I. Alteration in myocardial oxygen balance during exercise after beta-adrenergic blockade in dogs. J Appl Physiol 49: 28-33, 1980.

62. Heyndrickx GR, Vilaine JP, Moerman EJ, and Leusen I. Role of prejunctional alpha 2-adrenergic receptors in the regulation of myocardial performance during exercise in conscious dogs. Circ Res 54: 683-693, 1984.

63. Hintze TH and Vatner SF. Reactive dilation of large coronary arteries in conscious dogs. Circ Res 54: 50-57, 1984.

64. Huang Y, Chan FL, Lau CW, Tsang SY, Chen ZY, He GW, and Yao X. Roles of cyclic AMP and $\mathrm{Ca} 2+$-activated $\mathrm{K}+$ channels in endothelium-independent relaxation by urocortin in the rat coronary artery. Cardiovasc Res 57: 824-833, 2003.

65. Ishibashi Y, Duncker DJ, Zhang J, and Bache RJ. ATP-sensitive K+ channels, adenosine, and nitric oxide-mediated mechanisms account for coronary vasodilation during exercise. Circ Res 82: 346-359, 1998. 
66. Ishikawa T, Eckman DM, and Keef KD. Characterization of delayed rectifier $\mathrm{K}+$ currents in rabbit coronary artery cells near resting membrane potential. Can $J$ Physiol Pharmacol 75: 1116-1122, 1997.

67. Jackson WF. Arteriolar tone is determined by activity of ATP-sensitive potassium channels. Am J Physiol 265: H1797-1803, 1993.

68. Jacobson KA and Gao ZG. Adenosine receptors as therapeutic targets. Nat Rev Drug Discov 5: 247-264, 2006.

69. Jacobson MA, Johnson RG, Luneau CJ, and Salvatore CA. Cloning and chromosomal localization of the human A2b adenosine receptor gene (ADORA2B) and its pseudogene. Genomics 27: 374-376, 1995.

70. Jones CJ, DeFily DV, Patterson JL, and Chilian WM. Endothelium-dependent relaxation competes with alpha 1- and alpha 2-adrenergic constriction in the canine epicardial coronary microcirculation. Circulation 87: 1264-1274, 1993.

71. Jones CJ, Kuo L, Davis MJ, DeFily DV, and Chilian WM. Role of nitric oxide in the coronary microvascular responses to adenosine and increased metabolic demand. Circulation 91: 1807-1813, 1995.

72. Kaneshiro T, Saitoh S, Machii H, Yamaguchi O, Ishibashi T, Maruyama Y, and Takeishi Y. Metabolic regulation of coronary vascular tone: role of hydrogen peroxide, purinergic components, and angiotensin. Eur J Pharmacol 645: 127-134, 2010.

73. Katsuda Y, Egashira K, Ueno H, Akatsuka Y, Narishige T, Arai Y, Takayanagi T, Shimokawa H, and Takeshita A. Glibenclamide, a selective inhibitor of ATP-sensitive $\mathrm{K}+$ channels, attenuates metabolic coronary vasodilation induced by pacing tachycardia in dogs. Circulation 92: 511-517, 1995. 
74. Kemp BK and Cocks TM. Adenosine mediates relaxation of human small resistance-like coronary arteries via A2B receptors. Br J Pharmacol 126: 1796-1800, 1999.

75. Kerbaul F, Benard F, Giorgi R, Youlet B, Carrega L, Zouher I, Mercier L, Gerolami V, Benas V, Blayac D, Gariboldi V, Collart F, and Guieu R. Adenosine A2A receptor hyperexpression in patients with severe SIRS after cardiopulmonary bypass. J Investig Med 56: 864-871, 2008.

76. Khan TA, Bianchi C, Araujo EG, Ruel M, Voisine P, Li J, Liddicoat JR, and Sellke FW. Cardiopulmonary bypass reduces peripheral microvascular contractile function by inhibition of mitogen-activated protein kinase activity. Surgery 134: 247-254, 2003.

77. Khan TA, Bianchi C, Araujo EG, Ruel M, Voisine P, and Sellke FW. Activation of pulmonary mitogen-activated protein kinases during cardiopulmonary bypass. J Surg Res 115: 56-62, 2003.

78. Khan TA, Bianchi C, Ruel M, Voisine P, Li J, Liddicoat JR, and Sellke FW. Mitogen-activated protein kinase inhibition and cardioplegia-cardiopulmonary bypass reduce coronary myogenic tone. Circulation 108 Suppl 1: II348-353, 2003.

79. Koller A and Bagi Z. Nitric oxide and $\mathrm{H} 2 \mathrm{O} 2$ contribute to reactive dilation of isolated coronary arterioles. Am J Physiol Heart Circ Physiol 287: H2461-2467, 2004.

80. Koller A and Bagi Z. On the role of mechanosensitive mechanisms eliciting reactive hyperemia. Am J Physiol Heart Circ Physiol 283: H2250-2259, 2002.

81. Komaru T, Kanatsuka H, and Shirato K. Coronary microcirculation: physiology and pharmacology. Pharmacol Ther 86: 217-261, 2000. 
82. Koos BJ. Adenosine A2a receptors and O2 sensing in development. Am J Physiol Regul Integr Comp Physiol 301: R601-622, 2011.

83. Korzick DH, Laughlin MH, and Bowles DK. Alterations in PKC signaling underlie enhanced myogenic tone in exercise-trained porcine coronary resistance arteries. J Appl Physiol 96: 1425-1432, 2004.

84. Kuo L and Chancellor JD. Adenosine potentiates flow-induced dilation of coronary arterioles by activating KATP channels in endothelium. Am J Physiol 269: H541-549, 1995.

85. Kuo L, Chilian WM, and Davis MJ. Coronary arteriolar myogenic response is independent of endothelium. Circ Res 66: 860-866, 1990.

86. Kuo L, Davis MJ, and Chilian WM. Endothelium-dependent, flow-induced dilation of isolated coronary arterioles. Am J Physiol 259: H1063-1070, 1990.

87. Kuo L, Davis MJ, and Chilian WM. Longitudinal gradients for endotheliumdependent and -independent vascular responses in the coronary microcirculation. Circulation 92: 518-525, 1995.

88. Kuo L, Davis MJ, and Chilian WM. Myogenic activity in isolated subepicardial and subendocardial coronary arterioles. Am J Physiol 255: H1558-1562, 1988.

89. Ledent C, Vaugeois JM, Schiffmann SN, Pedrazzini T, El Yacoubi M, Vanderhaeghen JJ, Costentin J, Heath JK, Vassart G, and Parmentier M. Aggressiveness, hypoalgesia and high blood pressure in mice lacking the adenosine A2a receptor. Nature 388: 674-678, 1997.

90. Liu Y, Zhao H, Li H, Kalyanaraman B, Nicolosi AC, and Gutterman DD. Mitochondrial sources of $\mathrm{H} 2 \mathrm{O} 2$ generation play a key role in flow-mediated dilation in human coronary resistance arteries. Circ Res 93: 573-580, 2003. 
91. Londos C, Cooper DM, and Wolff J. Subclasses of external adenosine receptors. Proc Natl Acad Sci U S A 77: 2551-2554, 1980.

92. MacCollin M, Peterfreund R, MacDonald M, Fink JS, and Gusella J. Mapping of a human A2a adenosine receptor (ADORA2) to chromosome 22. Genomics 20: 332-333, 1994.

93. Marala RB and Mustafa SJ. Immunological characterization of adenosine A2A receptors in human and porcine cardiovascular tissues. J Pharmacol Exp Ther 286: 1051$1057,1998$.

94. Mass H and Gwirtz PA. Myocardial flow and function after regional betablockade in exercising dogs. Med Sci Sports Exerc 19: 443-450, 1987.

95. Matoba T, Shimokawa H, Kubota H, Morikawa K, Fujiki T, Kunihiro I, Mukai Y, Hirakawa Y, and Takeshita A. Hydrogen peroxide is an endotheliumderived hyperpolarizing factor in human mesenteric arteries. Biochem Biophys Res Commun 290: 909-913, 2002.

96. Matoba T, Shimokawa H, Morikawa K, Kubota H, Kunihiro I, UrakamiHarasawa L, Mukai Y, Hirakawa Y, Akaike T, and Takeshita A. Electron spin resonance detection of hydrogen peroxide as an endothelium-derived hyperpolarizing factor in porcine coronary microvessels. Arterioscler Thromb Vasc Biol 23: 1224-1230, 2003.

97. Matoba T, Shimokawa H, Nakashima M, Hirakawa Y, Mukai Y, Hirano K, Kanaide H, and Takeshita A. Hydrogen peroxide is an endothelium-derived hyperpolarizing factor in mice. J Clin Invest 106: 1521-1530, 2000. 
98. Matrougui K, Maclouf J, Levy BI, and Henrion D. Impaired nitric oxide- and prostaglandin-mediated responses to flow in resistance arteries of hypertensive rats. Hypertension 30: 942-947, 1997.

99. Miller FJ, Jr., Dellsperger KC, and Gutterman DD. Myogenic constriction of human coronary arterioles. Am J Physiol 273: H257-264, 1997.

100. Ming Z, Parent R, and Lavallee M. Beta 2-adrenergic dilation of resistance coronary vessels involves KATP channels and nitric oxide in conscious dogs. Circulation 95: 1568-1576, 1997.

101. Miura H, Bosnjak JJ, Ning G, Saito T, Miura M, and Gutterman DD. Role for hydrogen peroxide in flow-induced dilation of human coronary arterioles. Circ Res 92: e31-40, 2003.

102. Miura H, Liu Y, and Gutterman DD. Human coronary arteriolar dilation to bradykinin depends on membrane hyperpolarization: contribution of nitric oxide and Ca2+-activated K+ channels. Circulation 99: 3132-3138, 1999.

103. Miura H, Wachtel RE, Liu Y, Loberiza FR, Jr., Saito T, Miura M, and Gutterman DD. Flow-induced dilation of human coronary arterioles: important role of Ca(2+)-activated K(+) channels. Circulation 103: 1992-1998, 2001.

104. Miyashiro JK and Feigl EO. Feedforward control of coronary blood flow via coronary beta-receptor stimulation. Circ Res 73: 252-263, 1993.

105. Miyashiro JK and Feigl EO. A model of combined feedforward and feedback control of coronary blood flow. Am J Physiol 268: H895-908, 1995.

106. Morrison RR, Talukder MA, Ledent C, and Mustafa SJ. Cardiac effects of adenosine in $\mathrm{A}(2 \mathrm{~A})$ receptor knockout hearts: uncovering $\mathrm{A}(2 \mathrm{~B})$ receptors. Am J Physiol Heart Circ Physiol 282: H437-444, 2002. 
107. Morrison RR, Teng B, Oldenburg PJ, Katwa LC, Schnermann JB, and Mustafa SJ. Effects of targeted deletion of A1 adenosine receptors on postischemic cardiac function and expression of adenosine receptor subtypes. Am J Physiol Heart Circ Physiol 291: H1875-1882, 2006.

108. Murphy TV, Spurrell BE, and Hill MA. Cellular signalling in arteriolar myogenic constriction: involvement of tyrosine phosphorylation pathways. Clin Exp Pharmacol Physiol 29: 612-619, 2002.

109. Mustafa SJ, Morrison RR, Teng B, and Pelleg A. Adenosine receptors and the heart: role in regulation of coronary blood flow and cardiac electrophysiology. Handb Exp Pharmacol: 161-188, 2009.

110. Narishige T, Egashira K, Akatsuka Y, Imamura Y, Takahashi T, Kasuya H, and Takeshita A. Glibenclamide prevents coronary vasodilation induced by beta 1adrenoceptor stimulation in dogs. Am J Physiol 266: H84-92, 1994.

111. Nayeem MA, Poloyac SM, Falck JR, Zeldin DC, Ledent C, Ponnoth DS, Ansari HR, and Mustafa SJ. Role of CYP epoxygenases in A2A AR-mediated relaxation using A2A AR-null and wild-type mice. Am J Physiol Heart Circ Physiol 295: H2068-2078, 2008.

112. Olanrewaju HA, Gafurov BS, and Lieberman EM. Involvement of K+ channels in adenosine $\mathrm{A} 2 \mathrm{~A}$ and $\mathrm{A} 2 \mathrm{~B}$ receptor-mediated hyperpolarization of porcine coronary artery endothelial cells. J Cardiovasc Pharmacol 40: 43-49, 2002.

113. Olanrewaju HA, Qin W, Feoktistov I, Scemama JL, and Mustafa SJ. Adenosine $\mathrm{A}(2 \mathrm{~A})$ and $\mathrm{A}(2 \mathrm{~B})$ receptors in cultured human and porcine coronary artery endothelial cells. Am J Physiol Heart Circ Physiol 279: H650-656, 2000.

114. Olsson RA. Myocardial reactive hyperemia. Circ Res 37: 263-270, 1975. 
115. Olsson RA and Gregg DE. Metabolic Responses during Myocardial Reactive Hyperemia in the Unanesthetized Dog. Am J Physiol 208: 231-236, 1965.

116. Otake A, Saitoh S, and Takeishi Y. Hydrogen peroxide generated from cardiac myocytes impacts metabolic dilation in coronary arterioles. Int Heart J 51: 125-128, 2010.

117. Pagliaro P, Senzaki H, Paolocci N, Isoda T, Sunagawa G, Recchia FA, and Kass DA. Specificity of synergistic coronary flow enhancement by adenosine and pulsatile perfusion in the dog. J Physiol 520 Pt 1: 271-280, 1999.

118. Palmer TM and Stiles GL. Identification of an A2a adenosine receptor domain specifically responsible for mediating short-term desensitization. Biochemistry 36: 832838, 1997.

119. Park WS, Han J, Kim N, Ko JH, Kim SJ, and Earm YE. Activation of inward rectifier $\mathrm{K}+$ channels by hypoxia in rabbit coronary arterial smooth muscle cells. Am $J$ Physiol Heart Circ Physiol 289: H2461-2467, 2005.

120. Peculis R, Latkovskis G, Tarasova L, Pirags V, Erglis A, and Klovins J. A Nonsynonymous Variant I248L of the Adenosine A3 Receptor Is Associated with Coronary Heart Disease in a Latvian Population. DNA Cell Biol, 2011.

121. Piersen CE, True CD, and Wells JN. A carboxyl-terminally truncated mutant and nonglycosylated A2a adenosine receptors retain ligand binding. Mol Pharmacol 45: 861-870, 1994.

122. Raff U, Ott C, John S, Schmidt BM, Fleischmann EH, and Schmieder RE. Nitric oxide and reactive hyperemia: role of location and duration of ischemia. Am J Hypertens 23: 865-869, 2010. 
123. Ramkumar V, Stiles GL, Beaven MA, and Ali H. The A3 adenosine receptor is the unique adenosine receptor which facilitates release of allergic mediators in mast cells. J Biol Chem 268: 16887-16890, 1993.

124. Richmond KN, Tune JD, Gorman MW, and Feigl EO. Role of K(ATP)(+) channels and adenosine in the control of coronary blood flow during exercise. $J$ Appl Physiol 89: 529-536, 2000.

125. Richmond KN, Tune JD, Gorman MW, and Feigl EO. Role of K+ATP channels in local metabolic coronary vasodilation. Am J Physiol 277: H2115-2123, 1999.

126. Rivers RJ, Hein TW, Zhang C, and Kuo L. Activation of barium-sensitive inward rectifier potassium channels mediates remote dilation of coronary arterioles. Circulation 104: 1749-1753, 2001.

127. Rongen GA, Lenders JW, Lambrou J, Willemsen JJ, Van Belle H, Thien T, and Smits P. Presynaptic inhibition of norepinephrine release from sympathetic nerve endings by endogenous adenosine. Hypertension 27: 933-938, 1996.

128. Rosolowsky M and Campbell WB. Role of PGI2 and epoxyeicosatrienoic acids in relaxation of bovine coronary arteries to arachidonic acid. Am J Physiol 264: H327$335,1993$.

129. Ruiter JH, Spaan JA, and Laird JD. Transient oxygen uptake during myocardial reactive hyperemia in the dog. Am J Physiol 235: H87-94, 1978.

130. Sabouni MH, Ramagopal MV, and Mustafa SJ. Relaxation by adenosine and its analogs of potassium-contracted human coronary arteries. Naunyn Schmiedebergs Arch Pharmacol 341: 388-390, 1990.

131. Saitoh S, Zhang C, Tune JD, Potter B, Kiyooka T, Rogers PA, Knudson JD, Dick GM, Swafford A, and Chilian WM. Hydrogen peroxide: a feed-forward dilator 
that couples myocardial metabolism to coronary blood flow. Arterioscler Thromb Vasc Biol 26: 2614-2621, 2006.

132. Samaha FF, Heineman FW, Ince C, Fleming J, and Balaban RS. ATPsensitive potassium channel is essential to maintain basal coronary vascular tone in vivo. Am J Physiol 262: C1220-1227, 1992.

133. Sato A, Terata K, Miura H, Toyama K, Loberiza FR, Jr., Hatoum OA, Saito T, Sakuma I, and Gutterman DD. Mechanism of vasodilation to adenosine in coronary arterioles from patients with heart disease. Am J Physiol Heart Circ Physiol 288: H16331640, 2005.

134. Sato H, Hori M, Kitakaze M, Takashima S, Inoue M, Kitabatake A, and Kamada T. Endogenous adenosine blunts beta-adrenoceptor-mediated inotropic response in hypoperfused canine myocardium. Circulation 85: 1594-1603, 1992.

135. Schror K. Possible role of prostaglandins in the regulation of coronary blood flow. Basic Res Cardiol 76: 239-249, 1981.

136. Setty S, Tune JD, and Downey HF. Nitric oxide modulates right ventricular flow and oxygen consumption during norepinephrine infusion. Am J Physiol Heart Circ Physiol 282: H696-703, 2002.

137. Sharifi Sanjani M, Teng B, Krahn T, Tilley SL, Ledent C, and Mustafa SJ. Contributions of $\mathrm{A} 2 \mathrm{~A}$ and $\mathrm{A} 2 \mathrm{~B}$ adenosine receptors in coronary flow responses in relation to KATP channel using $\mathrm{A} 2 \mathrm{~B}$ and $\mathrm{A} 2 \mathrm{~A} / 2 \mathrm{~B}$ double knockout mice. Am J Physiol Heart Circ Physiol, 2011.

138. Son YK, Park WS, Kim SJ, Earm YE, Kim N, Youm JB, Warda M, Kim E, and Han J. Direct inhibition of a PKA inhibitor, H-89 on KV channels in rabbit coronary arterial smooth muscle cells. Biochem Biophys Res Commun 341: 931-937, 2006. 
139. Sun D, Huang A, Mital S, Kichuk MR, Marboe CC, Addonizio LJ, Michler RE, Koller A, Hintze TH, and Kaley G. Norepinephrine elicits beta2-receptor-mediated dilation of isolated human coronary arterioles. Circulation 106: 550-555, 2002.

140. Sun Park W, Kyoung Son Y, Kim N, Boum Youm J, Joo H, Warda M, Ko JH, Earm YE, and Han J. The protein kinase A inhibitor, H-89, directly inhibits KATP and Kir channels in rabbit coronary arterial smooth muscle cells. Biochem Biophys Res Commun 340: 1104-1110, 2006.

141. Talukder MA, Morrison RR, Jacobson MA, Jacobson KA, Ledent C, and Mustafa SJ. Targeted deletion of adenosine A(3) receptors augments adenosine-induced coronary flow in isolated mouse heart. Am J Physiol Heart Circ Physiol 282: H21832189, 2002.

142. Talukder MA, Morrison RR, Ledent C, and Mustafa SJ. Endogenous adenosine increases coronary flow by activation of both A2A and A2B receptors in mice. J Cardiovasc Pharmacol 41: 562-570, 2003.

143. Tawfik HE, Schnermann J, Oldenburg PJ, and Mustafa SJ. Role of A1 adenosine receptors in regulation of vascular tone. Am J Physiol Heart Circ Physiol 288: H1411-1416, 2005.

144. Tawfik HE, Teng B, Morrison RR, Schnermann J, and Mustafa SJ. Role of A1 adenosine receptor in the regulation of coronary flow. Am J Physiol Heart Circ Physiol 291: H467-472, 2006.

145. Teng B, Ledent C, and Mustafa SJ. Up-regulation of A 2B adenosine receptor in A 2A adenosine receptor knockout mouse coronary artery. J Mol Cell Cardiol 44: 905914, 2008. 
146. Teng B, Roush KP, Nadeem A, Morrison RR, and Mustafa SJ. Reduced Atherosclerotic Lesions in A1 Adenosine Receptor (AR)/Apolipoprotein E (APOE) Double Knockout mice: Role for A1 AR in the Development of Atherosclerosis. Arterioscler Thromb Vasc Biol 29: e73-74, 2009.

147. Thengchaisri N and Kuo L. Hydrogen peroxide induces endothelium-dependent and -independent coronary arteriolar dilation: role of cyclooxygenase and potassium channels. Am J Physiol Heart Circ Physiol 285: H2255-2263, 2003.

148. Thengchaisri N, Miriel VA, and Rivers RJ. Multiple receptor subtypes and multiple mechanisms of dilation are involved in vascular network dilation caused by adenosine. Microvasc Res 77: 356-363, 2009.

149. Traverse JH, Wang YL, Du R, Nelson D, Lindstrom P, Archer SL, Gong G, and Bache RJ. Coronary nitric oxide production in response to exercise and endothelium-dependent agonists. Circulation 101: 2526-2531, 2000.

150. Tsunoda R, Okumura K, Ishizaka H, Matsunaga T, Tabuchi T, Tayama S, and Yasue H. Enhancement of myocardial reactive hyperemia with manganesesuperoxide dismutase: role of endothelium-derived nitric oxide. Cardiovasc Res 31: 537$545,1996$.

151. Tucker AL, Jia LG, Holeton D, Taylor AJ, and Linden J. Dominance of G(s) in doubly $\mathrm{G}(\mathrm{s}) / \mathrm{G}(\mathrm{i})$-coupled chimaeric $\mathrm{A}(1) / \mathrm{A}(2 \mathrm{~A})$ adenosine receptors in HEK-293 cells. Biochem J 352 Pt 1: 203-210, 2000.

152. Tune JD, Gorman MW, and Feigl EO. Matching coronary blood flow to myocardial oxygen consumption. J Appl Physiol 97: 404-415, 2004.

153. Tune JD, Richmond KN, Gorman MW, and Feigl EO. Control of coronary blood flow during exercise. Exp Biol Med (Maywood) 227: 238-250, 2002. 
154. Ungvari Z, Csiszar A, Bagi Z, and Koller A. Impaired nitric oxide-mediated flow-induced coronary dilation in hyperhomocysteinemia: morphological and functional evidence for increased peroxynitrite formation. Am J Pathol 161: 145-153, 2002.

155. Vequaud P, Pourageaud F, and Freslon JL. Role of nitric oxide and endothelium in the flow-induced dilation of rat coronary arteries under two preconstriction conditions. Clin Exp Pharmacol Physiol 26: 470-476, 1999.

156. Volk KA, Matsuda JJ, and Shibata EF. A voltage-dependent potassium current in rabbit coronary artery smooth muscle cells. J Physiol 439: 751-768, 1991.

157. von Beckerath N, Dittrich M, Klieber HG, and Daut J. Inwardly rectifying K+ channels in freshly dissociated coronary endothelial cells from guinea-pig heart. J Physiol 491 ( Pt 2): 357-365, 1996.

158. Wang MH, Zhang F, Marji J, Zand BA, Nasjletti A, and LaniadoSchwartzman M. CYP4A1 antisense oligonucleotide reduces mesenteric vascular reactivity and blood pressure in SHR. Am J Physiol Regul Integr Comp Physiol 280: R255-261, 2001.

159. Watkinson WP, Foley DH, Rubio R, and Berne RM. Myocardial adenosine formation with increased cardiac performance in the dog. Am J Physiol 236: H13-21, 1979.

160. Welsh DG, Nelson MT, Eckman DM, and Brayden JE. Swelling-activated cation channels mediate depolarization of rat cerebrovascular smooth muscle by hyposmolarity and intravascular pressure. J Physiol 527 Pt 1: 139-148, 2000.

161. Williams-Pritchard G, Knight M, Hoe LS, Headrick JP, and Peart JN. Essential role of EGFR in cardioprotection and signaling responses to A1 adenosine 
receptors and ischemic preconditioning. Am J Physiol Heart Circ Physiol 300: H2161$2168,2011$.

162. Yaar R, Jones MR, Chen JF, and Ravid K. Animal models for the study of adenosine receptor function. J Cell Physiol 202: 9-20, 2005.

163. Yada T, Shimokawa H, Hiramatsu O, Kajita T, Shigeto F, Goto M, Ogasawara Y, and Kajiya F. Hydrogen peroxide, an endogenous endothelium-derived hyperpolarizing factor, plays an important role in coronary autoregulation in vivo. Circulation 107: 1040-1045, 2003.

164. Yada T, Shimokawa H, Hiramatsu O, Shinozaki Y, Mori H, Goto M, Ogasawara Y, and Kajiya F. Important role of endogenous hydrogen peroxide in pacing-induced metabolic coronary vasodilation in dogs in vivo. J Am Coll Cardiol 50: 1272-1278, 2007.

165. Yamabe H, Okumura K, Ishizaka H, Tsuchiya T, and Yasue H. Role of endothelium-derived nitric oxide in myocardial reactive hyperemia. Am J Physiol 263: H8-14, 1992.

166. Yang Y, Jones AW, Thomas TR, and Rubin LJ. Influence of sex, high-fat diet, and exercise training on potassium currents of swine coronary smooth muscle. Am J Physiol Heart Circ Physiol 293: H1553-1563, 2007.

167. Zatta AJ and Headrick JP. Mediators of coronary reactive hyperaemia in isolated mouse heart. Br J Pharmacol 144: 576-587, 2005.

168. Zhan E, McIntosh VJ, and Lasley RD. Adenosine A2A and A2B receptors are both required for adenosine A1 receptor-mediated cardioprotection. Am J Physiol Heart Circ Physiol 301: H1183-1189, 2011. 
169. Zhang C, Hein TW, and Kuo L. Transmural difference in coronary arteriolar dilation to adenosine: effect of luminal pressure and K(ATP) channels. Am J Physiol Heart Circ Physiol 279: H2612-2619, 2000.

170. Zhao JL, Yang YJ, Pei WD, Sun YH, Chen JL, and Go RL. Intravenous adenosine reduces myocardial no-reflow by decreasing endothelin-1 via activation of the ATP-sensitive K+ channel. Acta Cardiol 63: 355-359, 2008.

171. Zhao Z, Makaritsis K, Francis CE, Gavras H, and Ravid K. A role for the A3 adenosine receptor in determining tissue levels of cAMP and blood pressure: studies in knock-out mice. Biochim Biophys Acta 1500: 280-290, 2000. 
CHAPTER TWO

\section{RATIONALE AND LIMITATIONS}


The isolated perfused heart (Langendorff heart system), especially for small animals, is one of the optimal approaches, having in mind, the quantity and quality of data that can be obtained in a laboratory setting. Nevertheless, this approach has its own advantages and disadvantages.

The isolated heart provides us with types of data, such as heart rate, left ventricle pressure, and coronary flow, in the absence of the confounding effects of other organs,systemic circulation, neurohormonal factors, etc. This characteristic is considered as an advantage since it allows the distinction of aforementioned factors from cardiac responses. The absence of neurohormonal and peripheral factors can often be compensated for, if required; for example catecholamines or other neurotransmitters may be included in perfusate and many other peripheral mediators can be added exogenously. However, this approach can also be considered a disadvantage in the sense that it makes the preparation one step further away from the physiological in vivo state. Nonetheless, without a doubt, the isolated heart system provides us with the ability of performing metabolic or pharmacological dose-response studies. Although one must take into account the fact that, as an ex vivo preparation, the isolated heartundergoes deterioration in time, but it is capable of providing data up to 3-4 hours.

Using the isolated heart system, we are also able to induce whole heart ischemia through flow occlusion; this is an approach that we used for our reactive hyperemia experiments. Anoxia or hypoxia at various degrees of oxygen deprivation (in the presence of normal flow) can also be easily imposed through manipulation of oxygenation rate or amount. Therefore, this approach provides us with a powerful tool for assessing many aspects of ischemia/hypoxia or even, if interested, ischemia-reperfusioninduced injury, in which case single coronary occlusion can be performed. 
It is important to know that we have two modes of operation of the isolated perfused heart systems: constant flow and constant pressure. Whereas constant flow perfusion eliminates a variable from the experiment, it also has the disadvantage that, unlike constant pressure perfusion, autoregulatory coronary flow mechanisms are overridden and, therefore, it does not provide us with data regarding coronary flow regulation. Switching between constant flow and constant pressure modes of perfusion is not very straightforward so that it can be feasible within a single experimental protocol. However, currently, this system is now commercially available through ADInstruments Ltd. which allows us to switch instantly between constant pressure and constant flow modes of perfusion, enabling perfusion pressures and coronary flow to be controlled over a wide range. This feature is of considerable advantage in many studies of vascular function.

Using isolated perfused heart, several types of data can be gathered; for the purpose of morphology and vascular anatomy studies, heart or vascular fixation can be easily performed through coronary perfusion of required agents and a sequential analysis using light or electron microscopy. Additionally, the heart can be sliced, starting at the apex of the heart and working towards the base, for histology studies of coronary arteries. The whole heart can also be used for gross morphology such as is required during infarct size or cardiac hypertrophy studies. From a biochemistry/physiology point of interest, arterio-venous substrate concentration differences for metabolites, oxygen, and a host of other factors involved during physiological and extreme metabolism can be measured. Additionally, measurement of cellular constituents such as enzymes and proteins can be performed for the assessment of tissue injury due to the influence of, for example, various conditions such as ischemia/reperfusion or hypoxia. Microelectrodes can further be used 
for continuous measurement of interstitial $\mathrm{K}^{+}, \mathrm{Ca}^{2+}, \mathrm{pH}$ or monophasic action potentials. With all that in mind, using isolated heart perfusion the coronary perfusion, can be used for delivery of vectors in gene transfer studies where adenovirus or other vectors can be selectively delivered to the coronary artery vasculature and hence providing us with a so called "organ specific gene modification", which may replace whole animal knockout models as an approach which may exclude the effect of compensatory mechanisms due to the general whole animal gene modification.

From a more functional standpoint, using the isolated heart system, electrocardiographic recordings allow the detection, identification, and quantification of cardiac arrhythmias. Furthermore, the Langendorff preparation provides valuable information on left ventricular systolic and diastolic pressures and derivatives such as dp/dt. Various ultrasound techniques, such as echocardiography and Doppler, can also be used for measurements of cardiac wall thickening, stroke volume, cardiac output, coronary flow velocity, etc. While most studies with the isolated perfused heart are focused on the function and malfunction of the cardiomyocyte, using contractile and metabolic endpoints, it should be highlighted that Langendorff heart system can be used to study vascular reactivity, endothelial and smooth muscle function, and the effect of a variety of agents and drugs on coronary flow. Indeed, the isolated heart has been the foundation of much of the work on the no reflow phenomenon where $A_{2} A R s$ agonists are currently being clinically investigated as an approach for reduction of reperfusion injury. Nevertheless, even from basic therapeutic approaches, the isolated heart preparation is reliable for assessing the direct cardiovascular effects of various therapeutic agents in terms of contractile function, electrical activity, or metabolic function. This preparation allows us to perform dose-response studies with reproducibility and precise control of 
agent concentration. An additional advantage is that we are able to washout drugs from the circulation by replacing perfusion fluids which itself can be an excellent approach to study drug tachyphylaxis or desensitization.

There are also further important issues to consider when using the isolated heart system. Like so many other aspects of heart perfusion, the decision of whether to pace the heart or not, is based on a compromise between protocol requirements and quality of data. Heart rate in isolated hearts, when left to contract spontaneously, undergoes a progressive time-dependent decline. Spontaneous heart rate, in a perfused heart system, is usually significantly below the physiological normal rate. Mouse heart rate, in an in vivo preparation, is about 500 beats/min, whereas heart rate of about 380 beats/min, can be expected in the ex vivo preparation. This decline in baseline heart rate, of course, adds an additional variable, which itself may also vary among the animals. Moreover, this decline in heart rate also adds variability to the measurements obtained for left ventricular pressure. During an experiment, the worsening of HR depends on a large number of factors including the skills of the worker, avoidance of injury, the species being used, the composition of the perfusion fluid, the drugs used, age, HR and work load, and the temperature at which the studies are carried out. During a Langendorff heart preparation experiment, a deterioration rate of contractile function of about 5-10\% per hour is expected. Therefore, the rate of deterioration should be taken into account for the interpretation of studies and the experiments should be more or less time-matched with corrections for baseline deterioration when comparing groups.

Use of the isolated heart perfusion approach is reported in many large animals such as pigs, monkeys, sheep, dogs and even humans. Nevertheless, such studies are less frequently performed due to many limiting factors such as high cost, presence of greater 
variability in results, need forf large volumes of perfusion fluid and specialized equipment required. The availability of transgenic technology for mice undoubtedly resulted in increasing numbers of studies using murine preparations. Indeed, one of the reasons to use mouse, in our laboratory, was the availability of AR KO mice. Currently, the literature consists of an increasing number of studies which employ mouse hearts although the high HR ofmice may set some limitations for translation of data obtained from this species to human studies. Another limitation in the use of mice, in some studies, is the very small size of all organs or tissues. For example, the size of many arteries, such as large conduit coronary arteries, is in $\sim 80 \mu \mathrm{m}$ range, which shows a very smaller size range for the coronary resistance vessels. The size of these vessels somehow limits the study of coronary arteries in that the isolation of the actual resistance vessels is extremely challenging. Also, the use of a larger number of animals is required in order to obtain sufficient amount of tissue for the purpose of even basic experiments such as RT-PCR or western blot. Another limitation with the use of mice is the miniaturization of equipment; handling of rat hearts, for example, has a great advantage over smaller hearts from mice where intraventricular pressure recordings are more difficult. The rat does, however, suffer from very short action potential duration which can limit its value in terms of translation of data to human studies of arrhythmia and antiarrhythmic drugs. Other species, such as the rabbit, suffer problems with anesthesia and the guinea-pig heart differs from other species in that the coronary vasculature is totally collateralized, effectively preventing the study of regional ischemia in this species. Thus, as no ideal species or setting exists, in selecting a species or preparation for a specific study, it is crucial to recognize and appreciate the disadvantages and advantages. 


\section{CHAPTER THREE}

Contributions of $A_{2 A}$ and $A_{2 B}$ adenosine receptors in coronary flow responses in relation to $\mathrm{K}_{\mathrm{ATP}}$ channel using $\mathrm{A}_{2 \mathrm{~B}}$ and $\mathrm{A}_{2 \mathrm{~A} / 2 \mathrm{~B}}$ double knockout mice American Journal of Physiology, September 2011 (Used with permission from Am J Physiol Heart Circ Phsyiol, appendix B) 


\section{Abstract}

Adenosine plays a role in physiological and pathological conditions and $\mathrm{A}_{2}$ adenosine receptors (AR) expression is modified in many cardiovascular disorders. In this study, we elucidated the role of $A_{2 B} A R$ and its relationship to $A_{2 A} A R$ in coronary flow (CF) changes using $\mathrm{A}_{2 \mathrm{~B}}$ single $(\mathrm{KO})$ and $\mathrm{A}_{2 \mathrm{~A} / 2 \mathrm{~B}}$ double (DKO) knockout mice in Langendorff setup. We used two approaches: a) selective and non-selective AR agonists and antagonists, and b) $\mathrm{A}_{2 \mathrm{~A}}$ and $\mathrm{A}_{2 \mathrm{~B}} \mathrm{KO}$ and $\mathrm{A}_{2 \mathrm{~A} / 2 \mathrm{~B}} \mathrm{DKO}$. BAY60-6583 (selective $\mathrm{A}_{2 \mathrm{~B}}$ agonist) had no effect on $\mathrm{CF}(\mathrm{ml} / \mathrm{min} / \mathrm{g})$ in $\mathrm{A}_{2 \mathrm{~B}} \mathrm{KO}$ while it significantly increased the

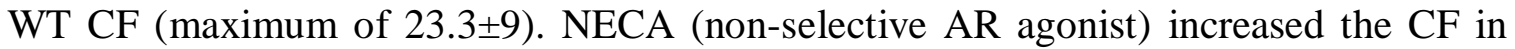
$\mathrm{A}_{2 \mathrm{~B}} \mathrm{KO}$ (maximum of $34.6 \pm 4.7$ ) to a significantly higher degree compared to WT (maximum of 23.1 \pm 2.1 ). Also, CGS21680 (selective $\mathrm{A}_{2 \mathrm{~A}}$ agonist) increased the $\mathrm{CF}$ in $\mathrm{A}_{2 \mathrm{~B}} \mathrm{KO}$ (maximum of $29 \pm 1.9$ ) to a significantly higher degree compared to WT

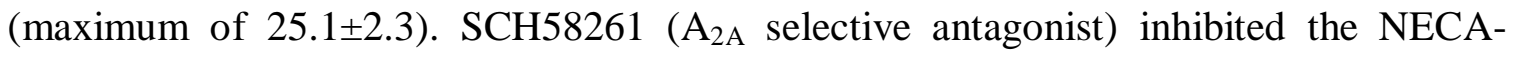
induced increase in $\mathrm{CF}$ to a significantly higher degree in $\mathrm{A}_{2 \mathrm{~B}} \mathrm{KO}(19.3 \pm 1.6$ vs. $0.5 \pm 0.4)$

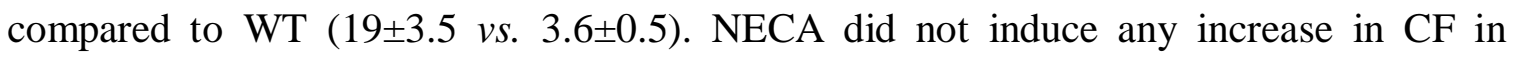
$\mathrm{A}_{2 \mathrm{~A} / 2 \mathrm{~B}} \mathrm{DKO}$ while a significant increase was observed in WT (maximum of 23.1 \pm 2.1 ). Furthermore, mitochondrial $\mathrm{K}_{\mathrm{ATP}}$ channel blocker 5-hydroxydecanoate had no effect on NECA-induced increase in CF in WT while NECA-induced increase in CF in WT (17.6 \pm 2$), \mathrm{A}_{2 \mathrm{~A}} \mathrm{KO}(12.5 \pm 2.3)$, and $\mathrm{A}_{2 \mathrm{~B}} \mathrm{KO}(16.2 \pm 0.8)$ was significantly blunted by $\mathrm{K}_{\mathrm{ATP}}$ channel blocker, glibenclamide, to $0.7 \pm 0.7,2.3 \pm 1.1$, and $0.9 \pm 0.4$, respectively. Also, CGS21680 (22 \pm 2.3$)$, and BAY60-6583 (16.4 \pm 1.60$)$-induced increase in CF in WT was significantly blunted by glibenclamide to $1.2 \pm 0.4$ and $1.8 \pm 1.2$, respectively. In conclusion, this is the first evidence supporting the compensatory up-regulation of $\mathrm{A}_{2 \mathrm{~A}} \mathrm{AR}$ in $\mathrm{A}_{2 \mathrm{~B}} \mathrm{KO}$ mice and demonstrating that both $\mathrm{A}_{2 \mathrm{~A}}$ and $\mathrm{A}_{2 \mathrm{~B}} \mathrm{ARs}$ induce $\mathrm{CF}$ changes 
through $\mathrm{K}_{\mathrm{ATP}}$ channels. These results identify AR-mediated $\mathrm{CF}$ responses which may lead to better therapeutic approaches for the treatment of cardiovascular disorders.

\section{Introduction}

Adenosine is an endogenous nucleoside which is released through the breakdown of adenine nucleotides. Adenosine's cardiovascular effects are mediated through activation of its four subtypes of receptors (AR), namely, $A_{1}, A_{2 A}, A_{2 B}$ and $A_{3}$. Activation of $A_{1} A R$ results in negative chronotropic and ionotropic effect, and a decrease in coronary flow (CF) (68) while other studies suggest that the activation of both $A_{1}$ or $\mathrm{A}_{3} \mathrm{ARs}$ prior to ischemia is cardioprotective $(6,30)$. However, adenosine is shown to play a vasoregulatory role in human coronary arteries $(16-17,62-63)$. It is well established that the activation of $A_{2 A} A R$ induces positive inotropic effect and that $A_{2 A} A R$ plays a major role in the regulation of $\mathrm{CF}$ in ex vivo models $(67,69)$. Additionally, in vivo studies in dogs showed the involvement of $\mathrm{A}_{2 \mathrm{~A}} \mathrm{AR}$ in $\mathrm{CF}$ (reactive hyperemia) regulation $(5,77)$ and thus, supporting a physiological role for adenosine. Adenosine-induced effects are species-dependent $(20,23)$. For example it is reported that guinea pig coronary vasodilation is more sensitive to adenosine compared to rats (72). Furthermore, few studies show that $\mathrm{A}_{2 \mathrm{~B}} \mathrm{AR}$ acts as a vasoconstricting as well as a vasodilating factor in different vascular beds $(13,57)$, in addition, to playing a cardioprotective role during ischemia/reperfusion $(14-15,30)$. Nevertheless, there are no reports fully elucidating the individual and relative role of $A_{2 B} A R$ in relation to $A_{2 A} A R$ in coronary vasodilation. Our group and others have previously suggested a role for $A_{2 B} A R$ in coronary artery vasodilation by means of indirect measures such as using non-selective agonist and antagonists and $\mathrm{A}_{2 \mathrm{~A}} \mathrm{KO}$ mice $(48,67)$ which are in accordance with previous reports 
showing $\mathrm{A}_{2} \mathrm{AR}$-mediacted vasodilation in isolated human coronary arteries $(39,63)$. Furthermore, this laboratory has shown the presence of $A_{2 B}$ and $A_{2 A} A R s$ in human and porcine coronary artery endothelial and vascular smooth muscle cells that may further support the involvement of $\mathrm{A}_{2 \mathrm{~A}}$ and $\mathrm{A}_{2 \mathrm{~B}} \mathrm{ARs}$ in the regulation of $\mathrm{CF}$ and a further possible interaction between these two receptor subtypes $(53,71)$. Coexpression of more than one AR subtype is also reported from other laboratories on human endothelial cells $(36,53)$ however, there are no reports studying whether the coexpressed receptors interact. We have recently shown an up-regulation of $\mathrm{A}_{2 \mathrm{~B}} \mathrm{AR}$ in $\mathrm{A}_{2 \mathrm{~A}} \mathrm{KO}$ mouse coronary artery suggesting an interrelationship between $\mathrm{A}_{2 \mathrm{~A}}$ and $\mathrm{A}_{2 \mathrm{~B}} \mathrm{ARs}$ subtypes since $\mathrm{A}_{2 \mathrm{~B}} \mathrm{AR}$ compensated for the down-regulation/deletion of $\mathrm{A}_{2 \mathrm{~A}} \mathrm{AR}$ (69). Additionally, since the involvement of $A_{2 \mathrm{~A}}$ and $\mathrm{A}_{2 \mathrm{~B}} \mathrm{ARs}$ and their down- or up-regulation is reported in many pathophysiological conditions $(2,40)$ and differential expression of ARs contributes to functional heterogeneity of human endothelial cells (21), elucidating the presence of such compensatory mechanisms and signaling pathways for ARs is essential for better understanding of the heterogeneity of vascular responses and the regulation of $\mathrm{CF}$.

While $\mathrm{A}_{2 \mathrm{~B}} \mathrm{AR}$ is reported to induce its cardiovascular effects through activation of arachidonic acid pathway in vasculature (13), $\mathrm{A}_{2 \mathrm{~A}} \mathrm{AR}$-induced vascular effects are demonstrated to partly involve CYP expoxygenases (50). We and others have previously demonstrated that $\mathrm{A}_{2 \mathrm{~A}} \mathrm{AR}$-induced vasodilation is partly due to release of nitric oxide in mouse aorta and coronary arteries (69). However, $\mathrm{A}_{2 \mathrm{~B}} \mathrm{AR}$-induced vasodilation is both nitric oxide-dependent and -independent in mouse aortic conduit artery and coronary arteries, respectively $(1,69)$. Although $\mathrm{K}_{\mathrm{ATP}}$ channels are shown to be present in coronary artery cells $(28,65)$ and $\mathrm{K}^{+}$channels in general are known to be involved in $\mathrm{A}_{2 \mathrm{~A}}$ and $\mathrm{A}_{2 \mathrm{~B}}$ ARs-mediated hyperpolarization of coronary arteries $(31,39,52)$, the involvement of 
$\mathrm{K}_{\mathrm{ATP}}$ channels in adenosine-induced coronary artery responses remains poorly understood.

The purpose of the present study was to directly and more fully elucidate the individual contribution of $\mathrm{A}_{2 \mathrm{~B}} \mathrm{AR}$ and its relationship to $\mathrm{A}_{2 \mathrm{~A}} \mathrm{AR}$ in $\mathrm{A}_{2} \mathrm{ARs}$-mediated induction of coronary artery vasodilation in light of the $\mathrm{K}_{\mathrm{ATP}}$ channel involvement. The hypotheses to be tested were; a) $\mathrm{A}_{2 \mathrm{~B}} \mathrm{AR}$ contributes to coronary vasodilation, b) $\mathrm{A}_{2 \mathrm{~A}}$ and $\mathrm{A}_{2 \mathrm{~B}} \mathrm{ARs}$ interact to induce coronary artery vasodilation and they each compensate for the deletion/down-regulation of the other, and c) $\mathrm{A}_{2 \mathrm{~A}}$ and $\mathrm{A}_{2 \mathrm{~B}} \mathrm{ARs}$-induced increase in $\mathrm{CF}$ is the result of activation of $\mathrm{K}_{\mathrm{ATP}}$ channels. Since there are inconsistencies between the results obtained from transgenic models compared to those obtained using pharmacological approaches (55), in this study, we have used both pharmacological and molecular (targeted gene deleted mouse model) approaches. Furthermore, we used $\mathrm{A}_{2 \mathrm{~A} / 2 \mathrm{~B}} \mathrm{DKO}$ mice to remove any possible compensatory up-regulation of either $\mathrm{A}_{2 \mathrm{~A}}$ or $\mathrm{A}_{2 \mathrm{~B}} \mathrm{AR}$ in $\mathrm{CF}$ responses.

\section{Methods}

All experimental protocols were performed according to the West Virginia University guidelines and approval of Animal Care and Use Committee.

Generation of DKO mice. $\mathrm{A}_{2 \mathrm{~A}}$-/- mice (backcrossed 12 generations to the C57BL/6 background) were bred with $\mathrm{A}_{2 \mathrm{~B}}-/$ - mice (backcrossed 12 generations to the C57BL/6 background) to generate $\mathrm{A}_{2 \mathrm{~A}}+/-\mathrm{A}_{2 \mathrm{~B}}+/-$ double heterozygotes. These double heterozygotes were then intercrossed, and $1 / 16$ of the resultant offspring were $A_{2 A}-/-A_{2 B}$ -/- DKOs. Male and female DKO breeding pairs were established from these animals to 
produce DKO mice. Since both $\mathrm{A}_{2 \mathrm{~A}}$-/- and $\mathrm{A}_{2 \mathrm{~B}}$-/- mice were inbred on C57BL/6, DKO are also inbred.

$W T, A_{2 A}$, and $A_{2 B} K O$ and $A_{2 A / 2 B} D K O$ mice. Hearts were isolated from age-matched 10 to 14 weeks old mice. WT mice of a mixed C57BL/6 genetic background were purchased from The Jackson Laboratory (Bar Harbor, Maine). $\mathrm{A}_{2 \mathrm{~B}} \mathrm{KO}$ and $\mathrm{A}_{2 \mathrm{~A} / 2 \mathrm{~B}} \mathrm{DKO}$ mice of the same background were generously provided by Dr. Stephen Tilley, Department of Medicine, University of North Carolina, Chapel Hill, NC. $\mathrm{A}_{2 \mathrm{~A}} \mathrm{KO}$ mice of the same background were generously provided by Dr. Catherine Ledent, Universite Libre de Bruxelles, Brussels, Belgium. All four strains were bred at the West Virginia University animal facility as a sub-colony of the original strain. The mice were kept in cages with 12:12-hr light-dark cycles and maintained on a standard laboratory diet with access to water ad libitum. All animal care and experimentation were in accordance with the West Virginia University Institutional Animal Care and Use Committee and the principles of the National Institutes of Health "Guide for the Care and Use of Laboratory Animals."

Chemicals. All chemicals were prepared as $10 \mathrm{mM}$ stock using Dimethyl Sulfoxide (DMSO, Sigma) followed by serial dilution with 50\% DMSO and distilled water and further dilution to desired concentration was achieved with distilled water (final DMSO concentration of < 1\%). NECA (5'-N-ethylcarboxamido adenosine), CGS21680, 5-hydroxydecanoate, and glibenclamide were bought from Sigma (St. Louis, MO, USA) and SCH58261 was a gift from Schering-Plough, Italy. $\mathrm{A}_{2 \mathrm{~B}}$ agonist, BAY606583, was a gift from Bayer (Germany). All stated concentrations are the actual drug concentration delivered as $1 \%$ of coronary flow. 
Langendorff-perfused mouse heart preparation. Isolated heart experiments were performed in accordance with the methods published earlier from our lab (48). In brief, mice were anesthetized with intraperitoneal sodium pentobarbital $(50 \mathrm{mg} / \mathrm{kg})$. A thoracotomy was performed, and the hearts were removed into heparinized $(5 \mathrm{U} / \mathrm{ml})$ icecold Kreb-Hensleit $(\mathrm{KH})$ buffer. The hearts were retrogradely perfused rapidly through the aorta cannulated with a 20 -gauge, blunt-ended needle at a constant pressure of 80 mmHg with continuously gassed with $95 \% \mathrm{O}_{2}$ and $5 \% \mathrm{CO}_{2} \mathrm{KH}$ buffer containing $(\mathrm{mM})$ : $119 \mathrm{NaCl}, 11$ Glucose, $22 \mathrm{NaHCO}_{3}, 4.7 \mathrm{KCl}, 1.2 \mathrm{KH}_{2} \mathrm{PO}_{4}, 1.2 \mathrm{MgSO}_{4}, 2.5 \mathrm{CaCl}_{2}, 2$ Pyruvate and $0.5 \mathrm{EDTA}$ at $37^{\circ} \mathrm{C}$ in a standard Langendorff fashion and allowed to beat spontaneously. The left atrium was removed and the left ventricle was vented with a small polyethylene apical drain. A water-filled balloon made of plastic wrap was inserted into the left ventricle across the mitral valve, which was connected to a fluid-filled pressure transducer by polyethylene tubing for continuous measurement of left ventricular developed pressure (LVDP). Left ventricle diastolic pressure was adjusted to a pressure of $2-5 \mathrm{mmHg}$ by filling up the left ventricle balloon. Coronary flow was measured via a Transonic flow probe (Transonic Systems; Ithaca, NY) in the aortic perfusion line. Baseline coronary flow, LVDP, and heart rate (derived from the ventricular pressure trace) were monitored for 30 min during the equilibration period, which were recorded on a Power Lab data acquisition system (AD Instruments; ColoradoSpring, CO). Hearts with persistent arrhythmias or poor LVDP $(<80 \mathrm{mmHg})$ during the equilibration period were excluded from the study. To rule out the tachyphylaxis or desensitization, at the end of each antagonist experiment, after another washout period, a repeat infusion of the agonist was performed. 
Experimental Protocols. After 30 minutes of equilibrium, baseline coronary flow, heart rate, and developed pressure were measured in $\mathrm{WT}, \mathrm{A}_{2 \mathrm{~B}} \mathrm{KO}$, and $\mathrm{A}_{2 \mathrm{~A} / 2 \mathrm{~B}} \mathrm{DKO}$ isolated hearts. Concentration-response curve (CRC) $\left(10^{-10}-10^{-6} \mathrm{M}\right)$ were performed for BAY606583 ( $\mathrm{A}_{2 \mathrm{~B}}$ selective agonist), NECA (non-selective AR agonist) and CGS21680 (selective $\mathrm{A}_{2 \mathrm{~A}}$ agonist) by infusing the drugs into the coronary perfusate through an injection port directly proximal to the aortic cannula using a microinjection infusion pump (Harvard Apparatus; Holliston, MA). After equilibration period, each heart was perfused with increasing concentration of selected drug to develop a concentration-response relationship curve. Each drug concentration was given for 5 min with 10 min intervals to allow complete drug washout (or using recovery to baseline parameters). All concentrations are the actual concentration in the perfusate. Data were collected at the end of each infusion period and washout time, which was used as a reference for normalizing responses to the subsequent drug concentration. In the result section, actual values from CRCs (figures 1-2,4, and 6) are presented as the maximum response and values from the use of a single drug concentration in the presence and absence of an antagonist (Figures 5 and 7-9) are presented as the actual drug-induced effect (maximal response minus the baseline).

Antagonist experiment protocol. After 30 min equilibration period and measurement of baseline parameters, agonists, NECA $\left(10^{-8} \mathrm{M}\right.$, in $\mathrm{A}_{2 \mathrm{~B}} \mathrm{KO}$ mice, or $10^{-8} \mathrm{M}$, in $\mathrm{A}_{2 \mathrm{~A}} \mathrm{KO}$ mice, closest concentration to the $\mathrm{EC}_{50}$ obtained from previously performed experiments) (Figures 7 and 8), BAY60-6583 $\left(10^{-7} \mathrm{M}\right)$ (Figure 9), and CGS21680 $\left(5 \times 10^{-9} \mathrm{M}\right)$ (Figure 9), were infused for $5 \mathrm{~min}$ at $1 \%$ rate of coronary flow. The plateau effect of coronary flow, heart rate, and developed pressure were recorded and a 10 min washout interval was allowed to reach the baseline. This was followed by infusion of antagonists, SCH58261 
$\left(10^{-6} \mathrm{M}, \mathrm{A}_{2 \mathrm{~A}}\right.$ selective antagonist) (71) (Figure 5) or glibenclamide $\left(10^{-5} \mathrm{M}\right)$ (Figures 7-9), at $1 \%$ rate of coronary flow for at least $10 \mathrm{~min}$ after which, the agonist was also added to the infusion line for an additional $5 \mathrm{~min}$ (for a total of $15 \mathrm{~min}$ ). The baseline at the end of antagonist infusion was treated as the new baseline for the subsequent agonist responses. The data at the end of the $15 \mathrm{~min}$ (the end of infusion of both agonists and antagonists) were used to compare with data obtained from the first infusion of the agonist alone. At the end of the experiment, after at least 10 min of washout and reaching the baseline, the agonist was again infused in order to check for tachyphylaxis or desensitization.

Western Blot. Mouse mesenteric arterioles (up to third branch arterioles) homogenates were obtained from isolated and cleaned tissue using ice-cold lysis buffer consisting of $0.05 \mathrm{M}$ Tris-buffered saline, $\mathrm{pH} 7.4,1 \%$ Triton $\mathrm{X}-100,0.25 \%$ sodium deoxycholate, $150 \mathrm{mM}$ sodium chloride, $1 \mathrm{mM}$ EDTA, $1 \mathrm{mM}$ phenylmethylsulfonyl and Halt Protease Inhibitor Cocktail (Thermo Scientific) by way of glass homogenizer. Samples were then centrifuged for $15 \mathrm{~min}$ at $13,000 \mathrm{rpm}$ and the supernatant was stored at $-80^{\circ} \mathrm{C}$. Protein extracts $(30 \mu \mathrm{g}$ protein per well) were separated on NuPAGE $4-12 \%$ Bis-Tris Gels (Invitrogen) along with Novex Sharp Protein Standard, 3.5-260-kDa, (Invitrogen) run in parallel. Proteins were then transferred to a PVDF membrane (Millipore), blocked in 5\% milk for 1 hour and then probed with anti- $\mathrm{A}_{2 \mathrm{~A}} \mathrm{AR}$ Rabbit Polyclonal IgG antibody (45) developed in our laboratory for detection of $\mathrm{A}_{2 \mathrm{~A}} \mathrm{AR}$ protein with a dilution of $1: 1000$ in TBST $+0.5 \%$ milk overnight at $4{ }^{\circ} \mathrm{C}$ or with anti- $\beta$-actin (Santa Cruz Biotechnology) at a dilution of 1:5000 at room temperature for 1 hour. This was followed by incubation with a secondary horseradish peroxidase-conjugated antibody (anti-mouse and anti-rabbit immunoglobulins, respectively; Santa Cruz Biotechnology Inc.) for $1 \mathrm{~h}$ at room temperature. For detection of bands, the membranes 
were treated with an enhanced chemiluminescence reagent (GE Healthcare) for $1 \mathrm{~min}$ and subsequently exposed to ECL Hyperfilm (GE Healthcare). Relative band intensities were quantified by densitometry, and each sample was normalized to the $\beta$-actin values and calibrated to $\mathrm{A}_{2 \mathrm{~A}} \mathrm{AR}$ protein expression in WT.

Data and Statistical analysis. Western blot data and baseline functional data of $\mathrm{A}_{2 \mathrm{~A}} \mathrm{KO}, \mathrm{A}_{2 \mathrm{~B}} \mathrm{KO}$, and $\mathrm{A}_{2 \mathrm{~A} / 2 \mathrm{~B}} \mathrm{DKO}$ groups were compared to WT, analyzed by using $t$-test. Differences in dose response curves and responses to each drug at the same concentration between WT, $\mathrm{A}_{2 \mathrm{~B}} \mathrm{KO}, \mathrm{A}_{2 \mathrm{~A}} \mathrm{KO}$, and $\mathrm{A}_{2 \mathrm{~A} / 2 \mathrm{~B}} \mathrm{DKO}$ hearts were analyzed using two-way ANOVA for repeated measures. Antagonist-induced responses (HR, LVDP, and CF) for WT, $\mathrm{A}_{2 \mathrm{~A}} \mathrm{KO}$, and $\mathrm{A}_{2 \mathrm{~B}} \mathrm{KO}$ hearts were compared with $t$-test. Statistical comparisons were done on percent changes. Results were considered significant when $P<0.05$. Values are means \pm SEM. The $\mathrm{EC}_{50} \mathrm{~S}$ were calculated using Prism (Graphpad Software, La Jolla, CA).

\section{Results}

Baseline function in WT, $A_{2 A} K O, A_{2 B} K O$, and $A_{2 A / 2 B} D K O$ isolated hearts. Table 1 demonstrates the baseline parameters for coronary flow (CF), heart rate (HR), and left ventricle developed pressure (LVDP) for $\mathrm{A}_{2 \mathrm{~A}} \mathrm{KO}, \mathrm{A}_{2 \mathrm{~B}} \mathrm{KO}, \mathrm{A}_{2 \mathrm{~A} / 2 \mathrm{~B}} \mathrm{DKO}$, and WT mice after $30 \mathrm{~min}$ of equilibration of the isolated hearts as mentioned in the "materials and methods". The average body weight of $\mathrm{A}_{2 \mathrm{~B}} \mathrm{KO}$ mice was significantly lower compared to the WT while heart weight to body weight ratio were not significantly different in any KOs compared to WT. Furthermore, no significant baseline differences were observed in CF and HR in any of the KOs compared to WT while LVDP was significantly higher in $\mathrm{A}_{2 \mathrm{~A} / 2 \mathrm{~B}} \mathrm{DKO}$ compared to WT hearts (Table 1). 
Effect of $A_{2 B} A R$ activation on coronary flow. BAY60-6583 ( $\mathrm{A}_{2 \mathrm{~B}}$ selective agonist) caused a concentration-dependent increase in CF in WT whereas no effect was observed in $\mathrm{A}_{2 \mathrm{~B}} \mathrm{KO}$ mice (Figure 1A). BAY60-6583 increased the CF in WT mice (with a maximum of $23.3 \pm 9 \mathrm{ml} / \mathrm{min} / \mathrm{g}, \mathrm{n}=7$ ) to a significantly higher degree compared to $\mathrm{A}_{2 \mathrm{~B}} \mathrm{KO}$ (no response) (Figure 1A). BAY60-6583 had no effect on HR of either WT or $\mathrm{A}_{2 \mathrm{~B}} \mathrm{KO}$ (Figure 1B) while it induced a significant increase in LVDP from baseline in the WT animals to a maximum of $95.6 \pm 14.9 \mathrm{mmHg}$ (Figure 1C, $\mathrm{n}=7$ ). BAY60-6583 had no effect on LVDP in $\mathrm{A}_{2 \mathrm{~B}} \mathrm{KO}$ hearts (Figure 1C).

Contribution of $A_{2 A} A R$ in ARs-mediated coronary vasodilation of $A_{2 B} K O$ mice. Since we wanted to test if $A_{2 A} A R$ compensates for $A_{2 B} A R$ in producing coronary vasodilation in $\mathrm{A}_{2 \mathrm{~B}} \mathrm{KO}$ mice, we used NECA (non-selective $\mathrm{AR}$ agonist) in $\mathrm{A}_{2 \mathrm{~B}} \mathrm{KO}$ and WT mice. NECA increased the $\mathrm{CF}$ in $\mathrm{A}_{2 \mathrm{~B}} \mathrm{KO}$ mice (with a maximum of $34.6 \pm 4.7 \mathrm{ml} / \mathrm{min} / \mathrm{g}, \mathrm{n}=8$, and $\left.\mathrm{EC}_{50}: 6.8 \times 10^{-9} \pm 0.8 \mathrm{M}\right)$ to a significantly higher degree compared to WT mice (with a maximum of $23.1 \pm 2.1 \mathrm{ml} / \mathrm{min} / \mathrm{g}$, $\mathrm{n}=9$, and $\mathrm{EC}_{50}: 3.5 \times 10^{-}$ ${ }^{9} \pm 0.6 \mathrm{M}$ ) (Figure $2 \mathrm{~A}$ ). Furthermore, NECA induced a significant increase in LVDP of $\mathrm{A}_{2 \mathrm{~B}} \mathrm{KO}$ compared to WT with a maximum increase of $115.5 \pm 8.5 \mathrm{mmHg}$ and $77.5 \pm 11.6 \mathrm{mmHg}$, respectively (Figure $2 \mathrm{C}$ ), while a decrease in HR was noted in both WT and $\mathrm{A}_{2 \mathrm{~B}} \mathrm{KO}$ mice with no significant difference between the two groups (Figures 2B).

Up-regulation of $A_{2 A} A R$ expression in $A_{2 B} K O$ isolated mesenteric arterioles. We used mesenteric arterioles as resistance vessels to analyze $\mathrm{A}_{2 \mathrm{~A}} \mathrm{AR}$ expression level in $\mathrm{A}_{2 \mathrm{~B}} \mathrm{KO}$ mice. The $\mathrm{A}_{2 \mathrm{~A}} \mathrm{AR}$ protein was significantly increased in $\mathrm{A}_{2 \mathrm{~B}} \mathrm{KO}$ isolated mesenteric arterioles compared to WT (25.7\% higher expression, Figure 3, n=4, p<0.05) 
Up-regulation of $A_{2 A} A R$ in $A_{2 B} K O$ mice. CGS21680 increased the CF (ml/min/g) in $\mathrm{A}_{2 \mathrm{~B}} \mathrm{KO}$ mice $\left(27.2 \pm 2.6\right.$ at $5 \times 10^{-8} \mathrm{M}$ and $29 \pm 1.9$ at $10^{-7} \mathrm{M}$ with $\mathrm{EC}_{50}: 3.9 \times 10^{-9} \pm 0.7 \mathrm{M}$, $\mathrm{n}=7)$ to a significantly higher degree compared to WT $\left(22.4 \pm 1.5\right.$ at $5 \times 10^{-8} \mathrm{M}$ and $25.1 \pm 2.3$ at $10^{-7} \mathrm{M}$ with $\mathrm{EC}_{50}: 2.6 \times 10^{-9} \pm 0.7 \mathrm{M}, \mathrm{n}=7$ ) (Figure $4 \mathrm{~A}$ ). Additionally, CGS21680 caused a significant increase in LVDP $(\mathrm{mmHg})$ in $\mathrm{A}_{2 \mathrm{~B}} \mathrm{KO}\left(111.5 \pm 6.7\right.$ at $5 \times 10^{-8} \mathrm{M}$ and $113 \pm 8.1$ at $\left.5 \times 10^{-7} \mathrm{M}\right)$ compared to WT $\left(97.9 \pm 4.9\right.$ at $5 \times 10^{-8} \mathrm{M}$ and $93 \pm 6.1$ at $\left.5 \times 10^{-7} \mathrm{M}\right)$ while there were no difference between the HR induced by CGS21680 when comparing WT and $\mathrm{A}_{2 \mathrm{~B}} \mathrm{KO}$ (Figures 4B-C).

Up-regulation of $A_{2 A} A R$ in $A_{2 B} K O$ mice. To further confirm the up-regulation of $\mathrm{A}_{2 \mathrm{~A}} \mathrm{AR}$ in $\mathrm{A}_{2 \mathrm{~B}} \mathrm{KO}$ mice as a compensatory response for the regulation of $\mathrm{CF}$, we used SCH58261, $\mathrm{A}_{2 \mathrm{~A}}$ selective antagonist, and tested its effect on NECA $(10 \mathrm{nM})$-induced increase in $\mathrm{CF}$ in WT and $\mathrm{A}_{2 \mathrm{~B}} \mathrm{KO}$. SCH58261 $(1 \mu \mathrm{M})$ significantly decreased the baseline CF (ml/min/g) of WT (from $9.9 \pm 0.7$ to $6.8 \pm 0.7$ ) and $\mathrm{A}_{2 \mathrm{~B}} \mathrm{KO}$ (from $12.3 \pm 0.6$ to 7.7 \pm 1.1 , (Figure 5A). SCH58261 also caused a significantly higher inhibition of NECAinduced increase in $\mathrm{CF}(\mathrm{ml} / \mathrm{min} / \mathrm{g})$ in $\mathrm{A}_{2 \mathrm{~B}} \mathrm{KO}(19.3 \pm 1.6$ vs. $0.5 \pm 0.4 \mathrm{n}=4)$ compared to WT $(19 \pm 3.5$ vs. $3.6 \pm 0.5, \mathrm{n}=6)$ (Figure 5A). NECA at $10 \mathrm{nM}$ concentration and SCH58261 had no significant effect on $\mathrm{HR}$ in both WT and $\mathrm{A}_{2 \mathrm{~B}} \mathrm{KO}$ animals (Figure 5B). However, NECA significantly increased the LVDP (mmHg) in both $\mathrm{A}_{2 \mathrm{~B}} \mathrm{KO}$ (from $99.9 \pm 11.5$ to $141 \pm 20.8, \mathrm{n}=4$ ) and WT (from 89.5 \pm 4.4 to $123.1 \pm 4.5$, n=6) hearts (Figure 5C). SCH58261 significantly reduced the baseline LVDP (mmHg) in both $\mathrm{A}_{2 \mathrm{~B}} \mathrm{KO}$ (from $99.9 \pm 11.6$ to $84.2 \pm 12.2$ ) and WT (from $89.5 \pm 4.4$ to $80.6 \pm 5.2$ ) hearts. Additionally, SCH58261 significantly reduced the NECA-induced increase in LVDP in both $\mathrm{A}_{2 \mathrm{~B}} \mathrm{KO}$ and WT groups (34.9 \pm 5.9 vs. $2.8 \pm 1.5, \mathrm{n}=4$, and $33.6 \pm 5.7 v$ s. $6.7 \pm 4, \mathrm{n}=4$, respectively) compared to their respective controls (Figure 5C). 
Involvement of $A_{2 A}$ and $A_{2 B} A R s$ in producing coronary vasodilation. In order to rule out the compensatory response between $A_{2 \mathrm{~A}}$ and $\mathrm{A}_{2 \mathrm{~B}} \mathrm{ARs}$, NECA was used in $\mathrm{A}_{2 \mathrm{~A} / 2 \mathrm{~B}} \mathrm{DKO}$ mice (Figure 6). NECA did not induce any increase in $\mathrm{CF}$ in $\mathrm{A}_{2 \mathrm{~A} / 2 \mathrm{~B}} \mathrm{DKO}$ $(\mathrm{n}=5)$ while a concentration-dependent response was observed in WT with a maximum increase up to $23.1 \pm 2.1 \mathrm{ml} / \mathrm{min} / \mathrm{g}$ ( $\mathrm{n}=9$ ) (Figure 6A). Additionally, NECA-induced effect on LVDP (mmHg) was significantly lower in $\mathrm{A}_{2 \mathrm{~A} / 2 \mathrm{~B}}$ DKO (53 \pm 2 at $10^{-7} \mathrm{M}$ and $\left.\mathrm{EC}_{50}: 1.3 \times 10^{-8} \pm 0.4\right)$ compared to WT $\left(82.5 \pm 11.6\right.$ at $10^{-7} \mathrm{M}$ and $\left.\mathrm{EC}_{50}: 1.8 \times 10^{-8} \pm 0.2\right)$ (Figure 6C). However, the decrease in HR in WT was not different compared to $A_{2 \mathrm{~A} / 2 \mathrm{~B}} \mathrm{DKO}$ hearts (Figure 6B).

Involvement of $K_{A T P}$ channels in $A_{2 A}$ and $A_{2 B}$ ARs-induced increase in coronary flow. We used 5-hydroxydecanote (mitochondrial $\mathrm{K}_{\mathrm{ATP}}$ channel blocker, $10^{-4} \mathrm{M}$ ) to test its effect on NECA $\left(10^{-8} \mathrm{M}\right)$-induced increase in CF in WT mice. The NECA concentrations were chosen based on the $\mathrm{EC}_{50}$ obtained from previously performed experiments $\left(10^{-8} \mathrm{M}\right.$ in WT and $\mathrm{A}_{2 \mathrm{~B}} \mathrm{KO}$ and $5 \times 10^{-8} \mathrm{M}$ in $\mathrm{A}_{2 \mathrm{~A}} \mathrm{KO}$ ). 5-hydroxydecanote had no effect on NECAinduced increase in $\mathrm{CF}(\mathrm{ml} / \mathrm{min} / \mathrm{g})(15.3 \pm 2.8 v s .18 .5 \pm 3.1, \mathrm{n}=5$, Figure $7 \mathrm{~A})$. Additionally, 5-hydroxydecanote had no effect on NECA-induced changes in HR and LVDP (Figures 7B-C). Furthermore, we used glibenclamide ( $\mathrm{K}_{\mathrm{ATP}}$ channel blocker) to test its effect on NECA-induced increase in $\mathrm{CF}$ in $\mathrm{WT}, \mathrm{A}_{2 \mathrm{~A}}$ and $\mathrm{A}_{2 \mathrm{~B}} \mathrm{KO}$ mice (Figures $7 \mathrm{~A}$ and $8 \mathrm{~A}$ ). Glibenclamide significantly reduced NECA-induced increase in CF $(\mathrm{ml} / \mathrm{min} / \mathrm{g})$ in WT (17.6 \pm 2 vs. $0.7 \pm 0.7, \mathrm{n}=4$, Figure $7 \mathrm{~A}), \mathrm{A}_{2 \mathrm{~A}} \mathrm{KO}(12.5 \pm 2.3$ vs. $2.3 \pm 1.1, \mathrm{n}=5$, Figure $8 \mathrm{~A})$, and $\mathrm{A}_{2 \mathrm{~B}} \mathrm{KO}(16.2 \pm 0.8$ vs. $0.9 \pm 0.4, \mathrm{n}=5$, Figure $8 \mathrm{~A})$. However, glibenclamide did not change NECA-induced effect on $\mathrm{HR}(\mathrm{bpm})$ in $\mathrm{A}_{2 \mathrm{~A}}$ and $\mathrm{A}_{2 \mathrm{~B}} \mathrm{KO}$ while it significantly reduced the NECA-induced effect on HR in WT compared to its control (28.5 $\pm 9.7 v$ s. $-8.1 \pm 7.6)$ where it also significantly reduced the basal HR from $315.5 \pm 11.1$ to $236.6 \pm 15.2$ (Figures 
7B and 8B). Furthermore, glibenclamide did not change NECA-induced effect on LVDP in $\mathrm{A}_{2 \mathrm{~A}} \mathrm{KO}$ while significantly reduced the LVDP (mmHg) in WT (26.4 \pm 9.9 vs. $\left.1.2 \pm 3.6\right)$ and $\mathrm{A}_{2 \mathrm{~B}} \mathrm{KO}(16.7 \pm 3.3$ vs. $2.4 \pm 2.3, \mathrm{n}=5$ ) (Figures $7 \mathrm{C}$ and $8 \mathrm{C}$ ). To confirm the effect of glibenclamide we tested its effect on pinacidil ( $\mathrm{K}_{\mathrm{ATP}}$ channel opener as positive control). Glibenclamide significantly reduced pinacidil-induced increase in $\mathrm{CF}(\mathrm{ml} / \mathrm{min} / \mathrm{g})$ from baseline in WT $(19 \pm 3$ vs. 10.2 $\pm 1.8, \mathrm{n}=6)$. However, glibenclamide did not change pinacidil-induced effect on HR and LVDP in WT mice (Figure 7).

Additionally, we tested the effect of glibenclamide on CGS21680 ( $\mathrm{A}_{2 \mathrm{~A}}$ selective agonist) and BAY60-6583( $\mathrm{A}_{2 \mathrm{~B}}$ selective agonist)-induced increase in $\mathrm{CF}$ in WT (Figure 9A). Glibenclamide significantly reduced the effect of CGS21680 $\left(5 \times 10^{-9} \mathrm{M}\right)(22 \pm 2.3$, $\mathrm{n}=5)$ and BAY60-6583 $\left(10^{-7} \mathrm{M}\right)(16.4 \pm 1.6, \mathrm{n}=4)$ on $\mathrm{CF}(\mathrm{ml} / \mathrm{min} / \mathrm{g})$ to $1.2 \pm 0.4(\mathrm{n}=5)$ and $1.8 \pm 1.2(n=4)$, respectively (Figure 9A). In the presence of glibenclamide both the baseline and drug-induced effects on HR were significantly decreased compared to their control (Figure 9B). Additionally, glibenclamide significantly reduced CGS21680 and BAY-induced increase in LVDP $(\mathrm{mmHg}), 31.6 \pm 13.1$ vs. $1.9 \pm 4.7(\mathrm{n}=5)$ and $20.1 \pm 1.7$ vs. 7.7 $\pm 5.5(n=4)$, respectively (Figure 9C). 
Figure 3.1 Effect of BAY 60-6583 (BAY) in $\mathrm{A}_{2 \mathrm{~B}} \mathrm{KO}$ and WT mice on coronary flow (A), heart rate (B) and LVDP (left ventricle developed pressure) (C). *Significant difference compared to WT, $p<0.05$.
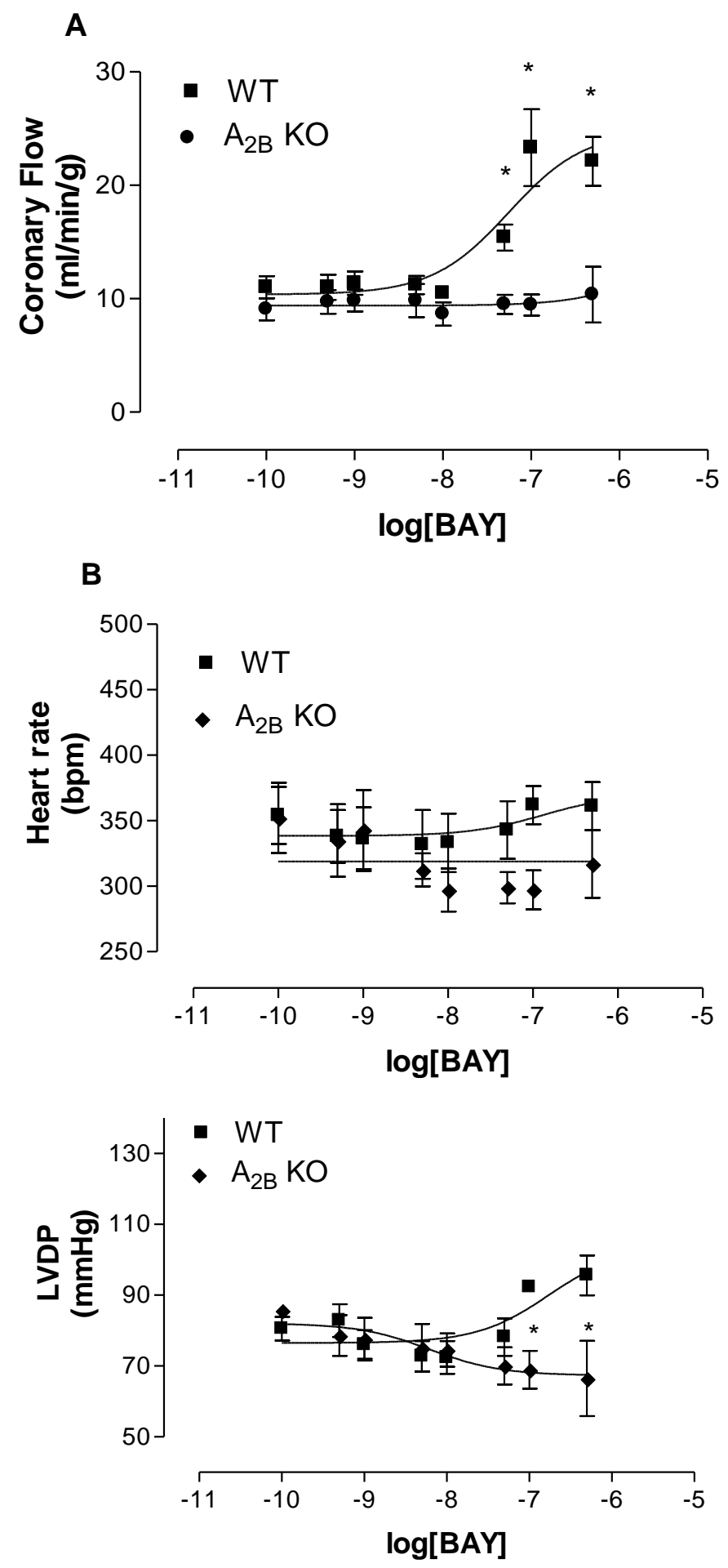
Figure 3.2 Effect of NECA in $\mathrm{A}_{2 \mathrm{~B}} \mathrm{KO}$ and WT mice on coronary flow (A), heart rate (B), and LVDP (C). *Significant difference compared to WT, $p<0.05$.
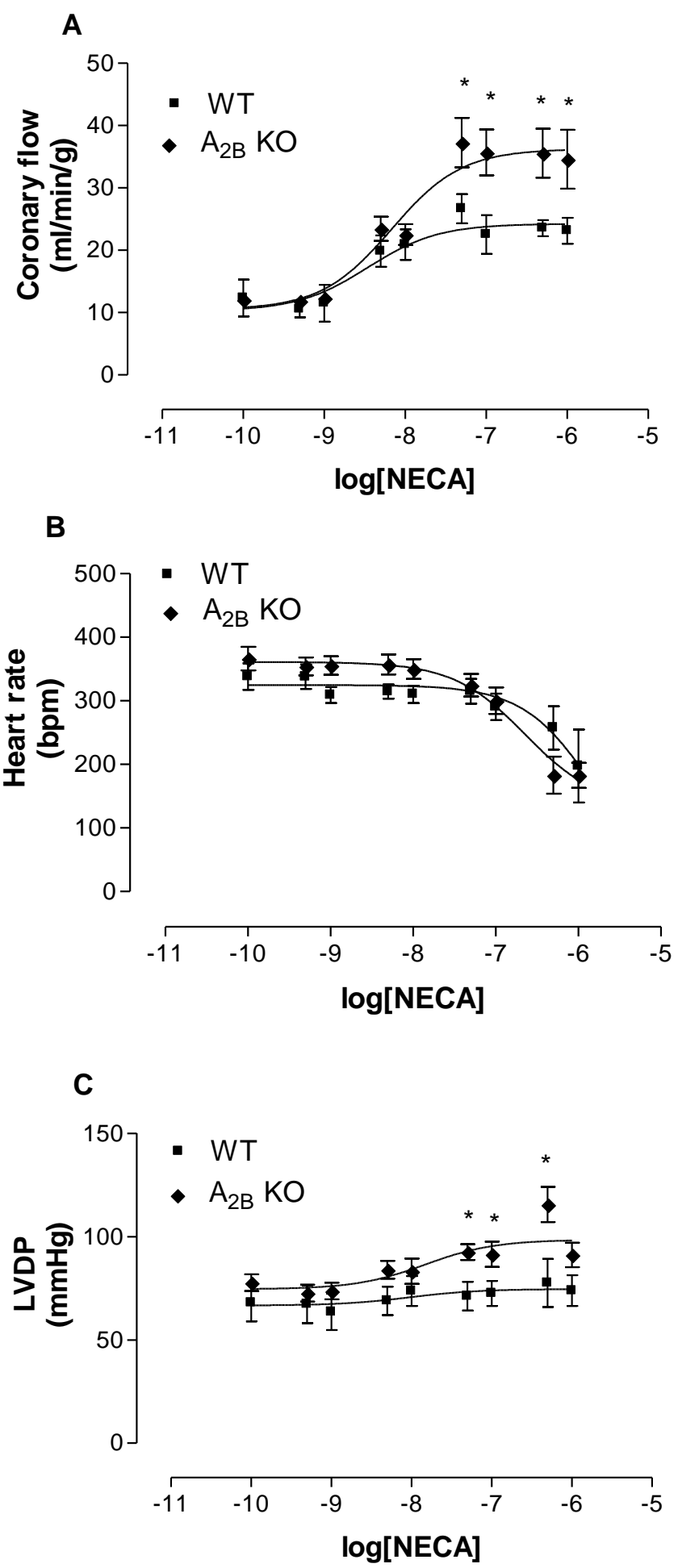
Figure 3.3 $A_{2 A} A R$ expression levels in $W T$ and $A_{2 B} K O$ isolated mesenrteric arterioles.*Significant difference compared to WT, $p<0.05$.
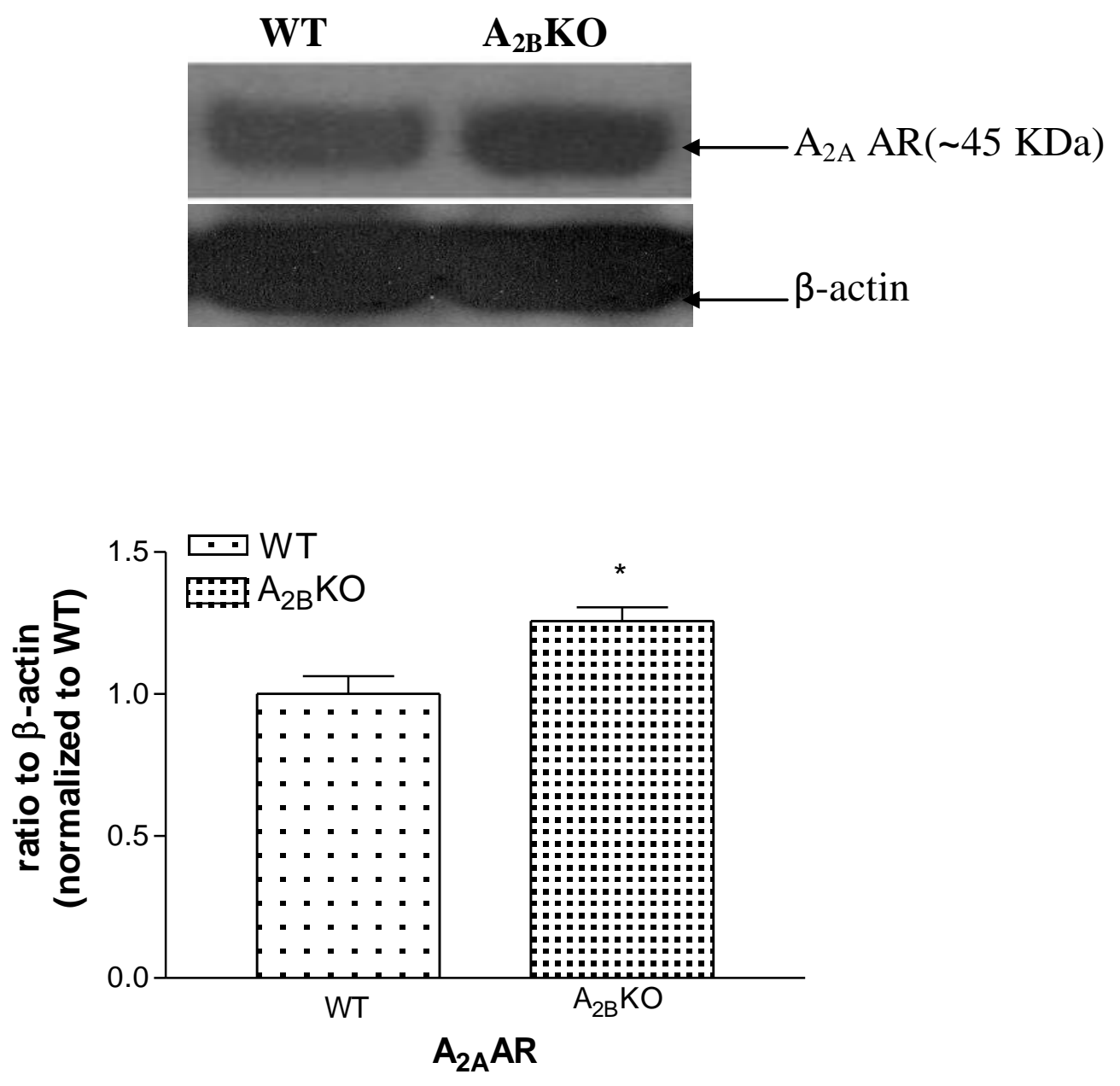
Figure 3.4 Effect of CGS 21680 in $\mathrm{A}_{2 \mathrm{~B}} \mathrm{KO}$ and WT mice on coronary flow (A), heart rate (B), and LVDP (C).*Significant difference compared to WT, $p<0.05$.

\section{A}

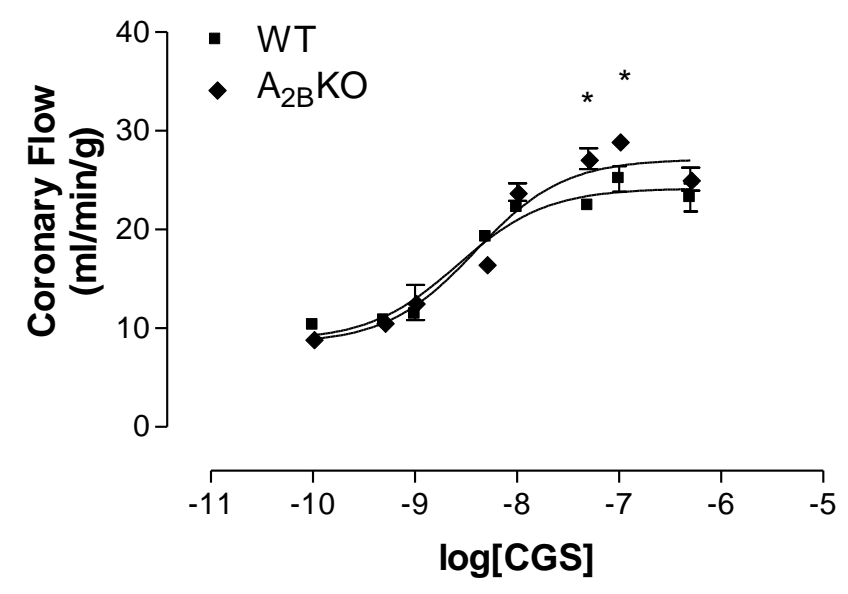

B

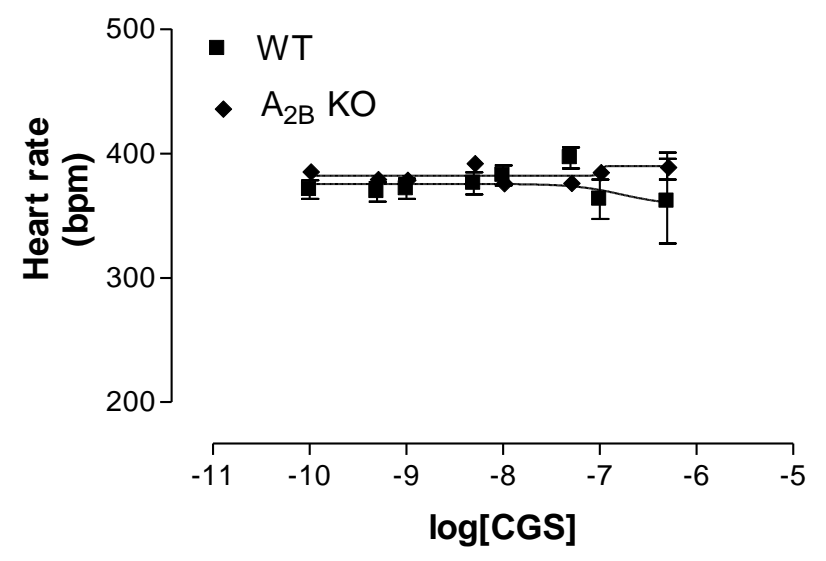

C

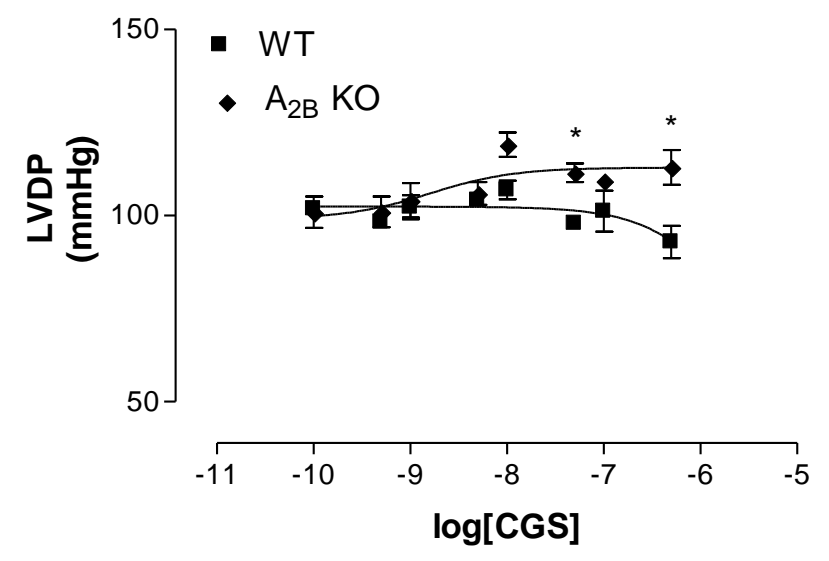


Figure 3.5 Effect of SCH $58261(1 \mu \mathrm{M})$ on NECA-induced increase in coronary flow (A), heart rate (B), and LVDP (C) in WT and $A_{2 B} K O$. *Significant difference between drug-induced effects in the presence of antagonist compared to their corresponding control. "Significant difference in baselines in the presence of antagonist compared to their corresponding control. ${ }^{\$}$ Significant difference between WT and $A_{2 B} K O$ antagonist treated groups, $p<0.05$.
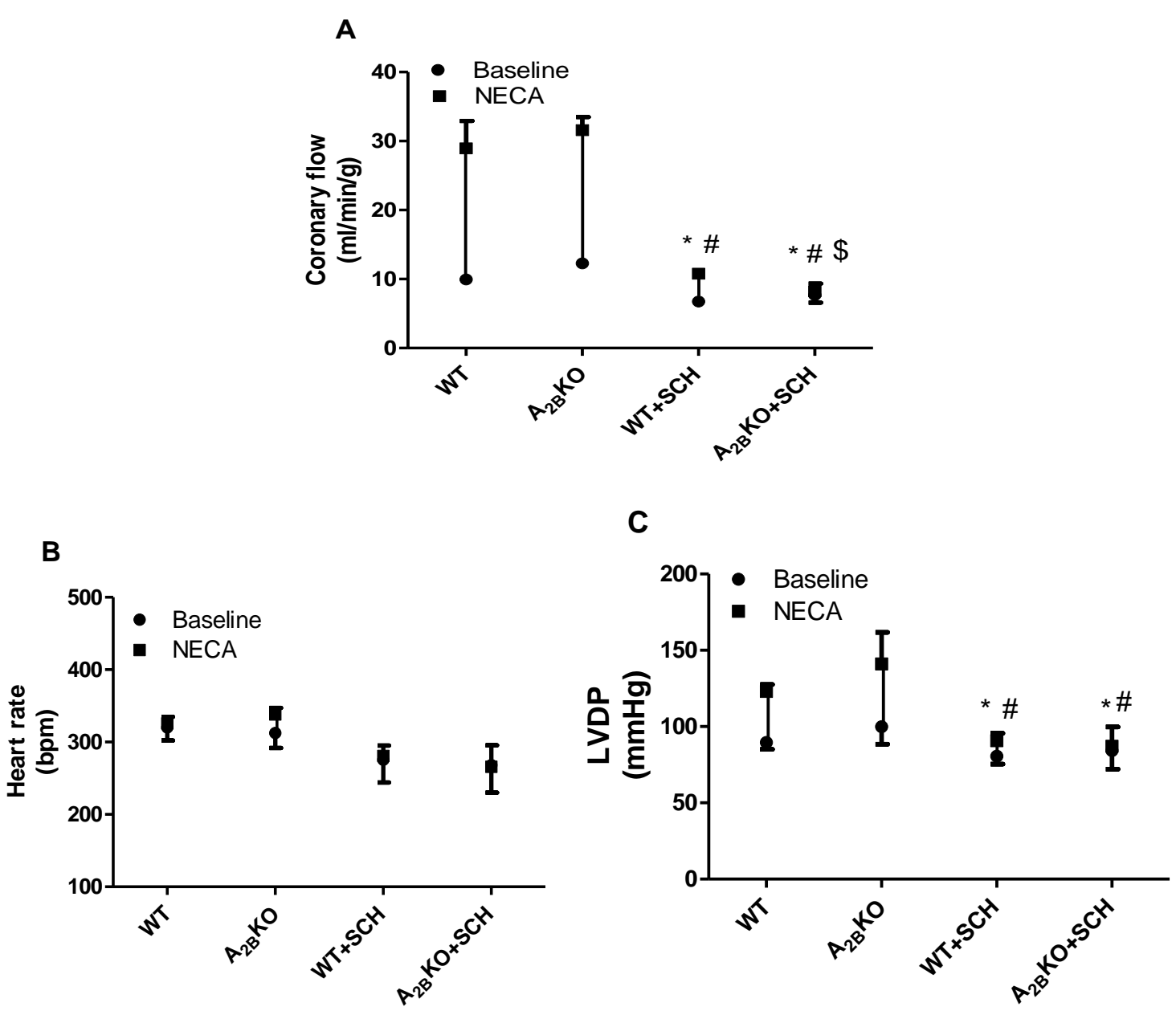
Figure 3.6 Effect of NECA in $A_{2 A} / 2 \mathrm{~B} D K O$ and WT mice on coronary flow (A), heart rate (B), and LVDP (C). *Significant difference compared to $\mathrm{WT}, \boldsymbol{p}<0.05$.
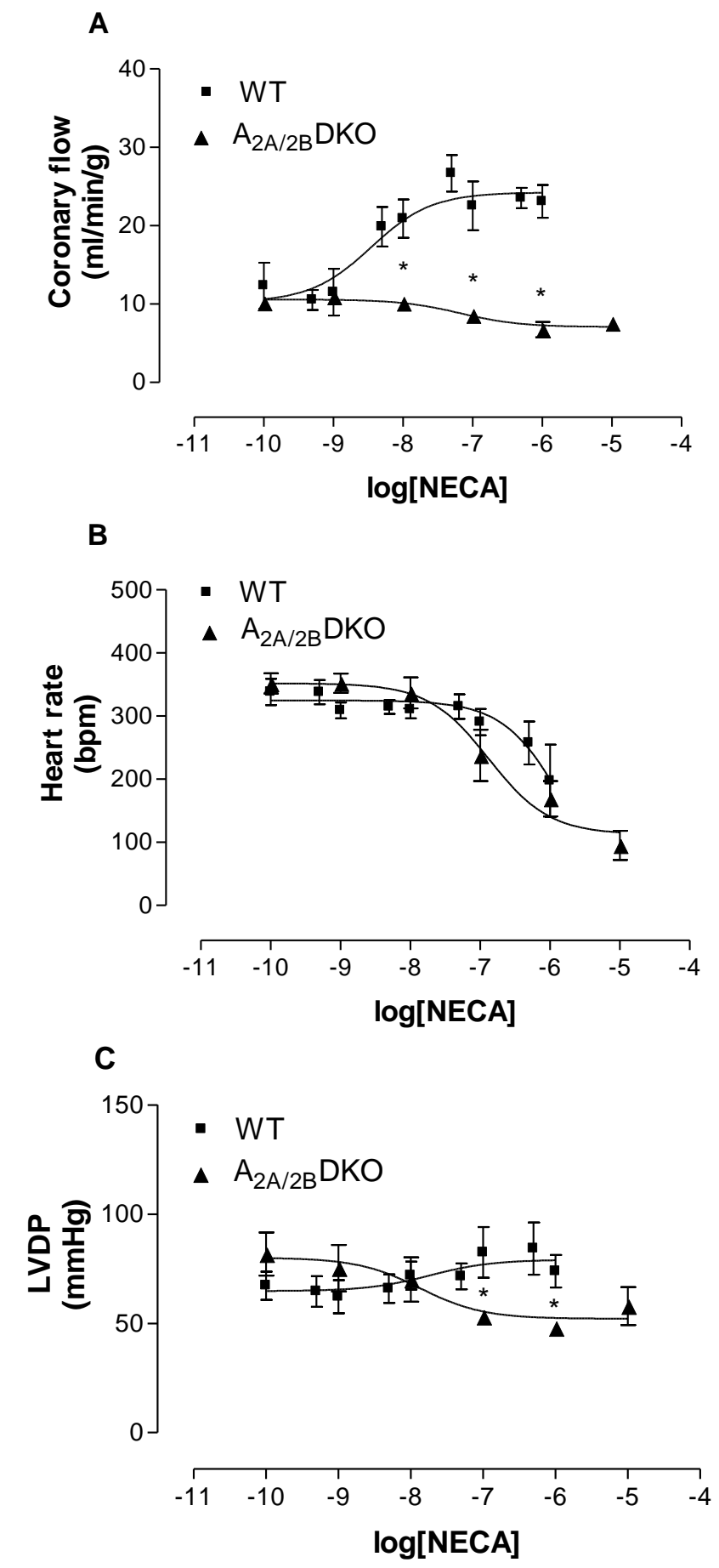
Figure 3.7 Effect of 5-hydroxydecanote (5-HD) on NECA-induced increase in coronary flow (A), heart rate (B), and LVDP (C) in WT and the effect of glibenclamide (GB) on NECA and pinacidil (PIN)-induced increase in coronary flow (A), heart rate (B), and LVDP (C) in WT.*Significant difference in drug-induced effects in the presence of antagonist compared to their corresponding control. "Significant difference in baselines in the presence of antagonist compared to their corresponding control, $p<0.05$.

A
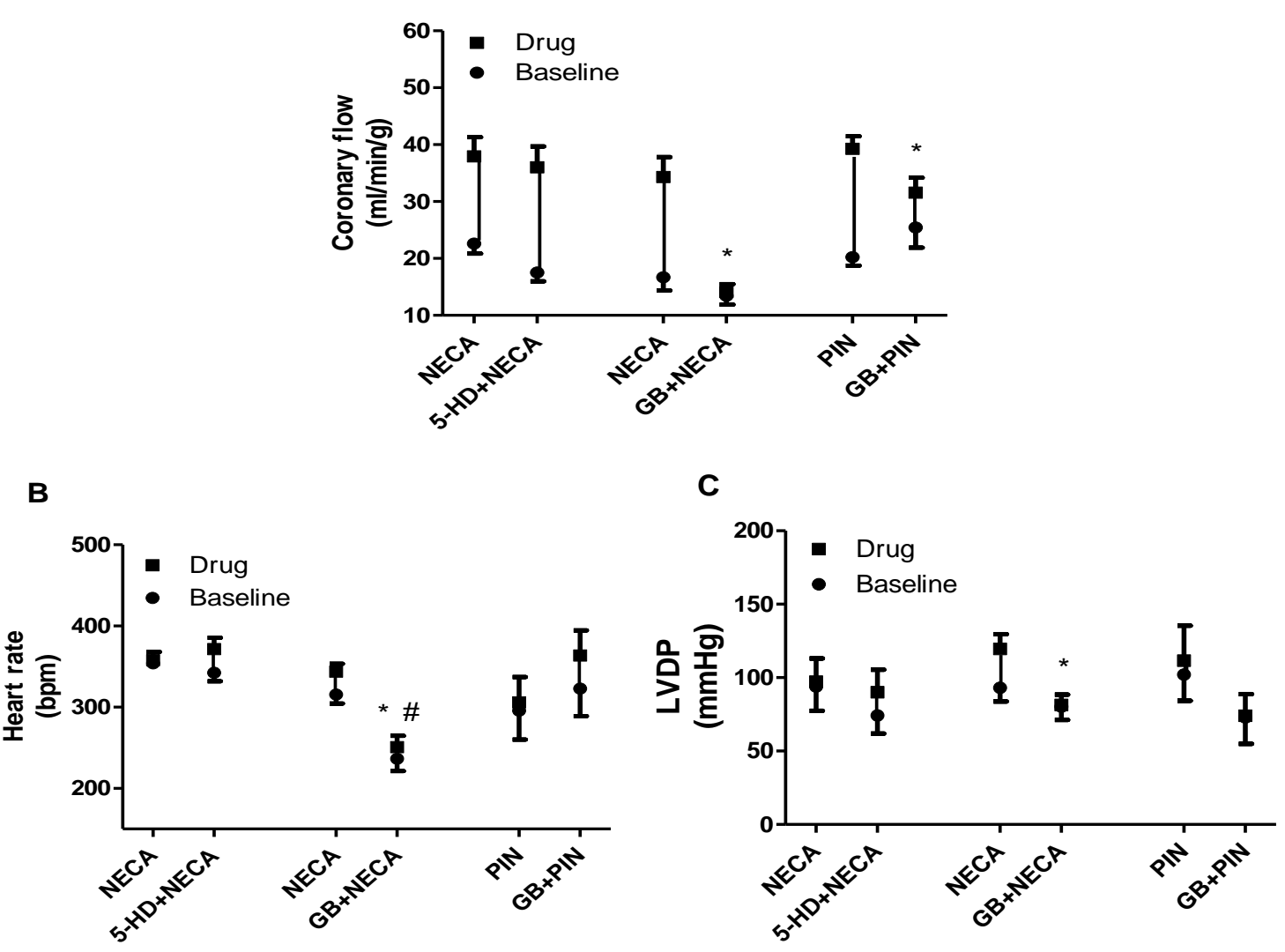
Figure 3.8 Effect of glibenclamide (GB) on NECA-induced increase in coronary flow (A), heart rate (B), and LVDP (C) in $A_{2 A} K O$ and $A_{2 B} K O$. *Significant difference in drug-induced effects in the presence of antagonist compared to their corresponding control, $p<0.05$.
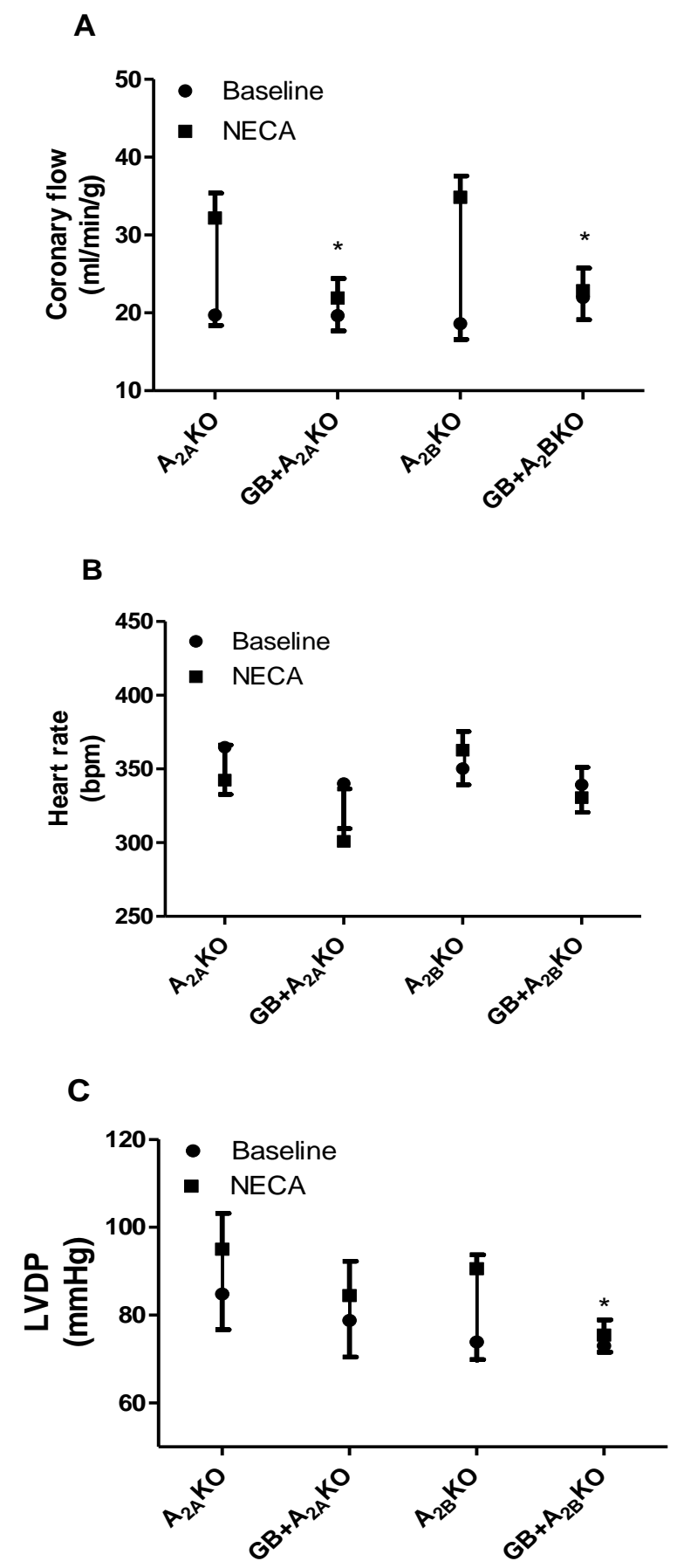
Figure 3.9 Effect of glibenclamide (GB) on CGS 21680 (CGS) and BAY 60-6583 (BAY)-induced increase in coronary flow (A), heart rate (B), and LVDP (C) in WT. *Significant difference in drug-induced effects in the presence of antagonist compared to their corresponding control. "Significant difference in baselines in the presence of antagonist compared to their corresponding control, $p<0.05$.
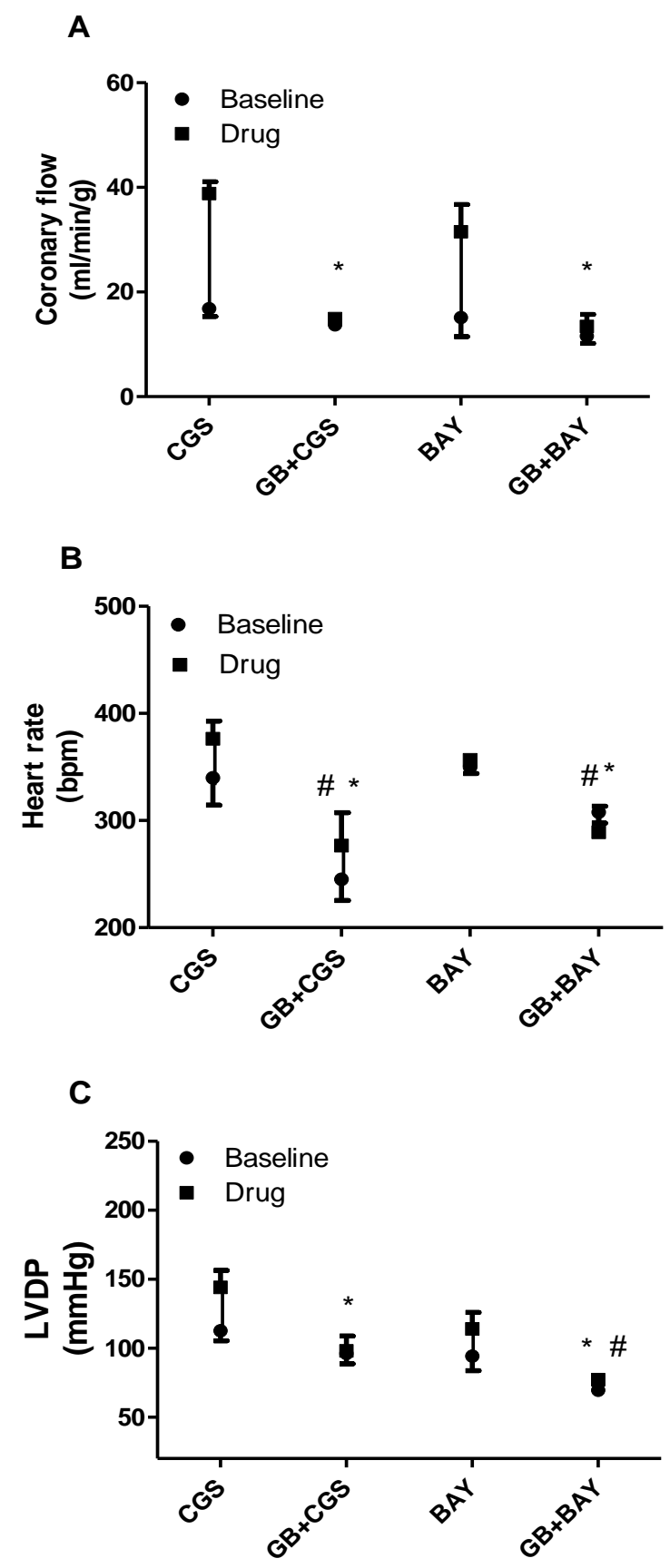
Table 3.1

Baseline data for $W T, A_{2 A} K O, A_{2 B} K O$, and $A_{2 A / 2 B} D K O$ mice hearts.

\begin{tabular}{|l|l|l|l|l|}
\hline & $\begin{array}{l}\text { Wild-Type } \\
\mathrm{n}=30\end{array}$ & $\begin{array}{l}\mathrm{A}_{2 \mathrm{~A}} \mathrm{KO} \\
\mathrm{n}=12\end{array}$ & $\begin{array}{l}\mathrm{A}_{2 \mathrm{~B}} \mathrm{KO} \\
\mathrm{n}=29\end{array}$ & $\begin{array}{l}\mathrm{A}_{2 \mathrm{~A} / 2 \mathrm{~B}} \mathrm{DKO} \\
\mathrm{n}=15\end{array}$ \\
\hline Body weight, g & $25 \pm 0.6$ & $25 \pm 1.2$ & $23.8 \pm 0.6^{*}$ & $24.7 \pm 1.1$ \\
\hline Heart weight, g & 0.1 & 0.1 & 0.1 & 0.1 \\
\hline $\begin{array}{l}\text { Heart-to-body } \\
\text { weight ratio, \% }\end{array}$ & $0.5 \pm 0.4$ & 0.4 & $0.4 \pm 0.1$ & 0.4 \\
\hline $\begin{array}{l}\text { Coronary flow, } \\
\text { ml.min }{ }^{-1} \cdot \mathrm{g}^{-1}\end{array}$ & $15.2 \pm 0.8$ & $17.2 \pm 0.9$ & $14.5 \pm 0.7$ & $15.6 \pm 1.8$ \\
\hline $\begin{array}{l}\text { Heart rate, } \\
\text { beats/min }\end{array}$ & $341.6 \pm 10.3$ & $356.8 \pm 14.5$ & $345.1 \pm 7.8$ & $330.4 \pm 17.8$ \\
\hline $\begin{array}{l}\text { Developed } \\
\text { pressure, mmHg }\end{array}$ & $80.3 \pm 4.2$ & $81.2 \pm 4.8$ & $83.3 \pm 3.3$ & $97.1 \pm 6.2^{*}$ \\
\hline
\end{tabular}

All parameters were collected after $30 \mathrm{~min}$ of equilibration in langendorff preparation. All values are means \pm S.E.M.* significantly different compared to WT. 


\section{Discussion}

In this study we have further elucidated the contribution of $A_{2 B} A R$ and its relationship to $\mathrm{A}_{2 \mathrm{~A}} \mathrm{AR}$ in $\mathrm{A}_{2} \mathrm{ARs}$-mediated coronary artery vasodilation. With the use of $\mathrm{A}_{2 \mathrm{~A} / 2 \mathrm{~B}} \mathrm{DKO}$ mice, we also showed for the first time that $\mathrm{A}_{2 \mathrm{~A}}$ and $\mathrm{A}_{2 \mathrm{~B}} \mathrm{ARs}$, out of four ARs subtypes, contribute to coronary artery vasodilation and down-regulation/deletion of either of $\mathrm{A}_{2 \mathrm{~A}}$ and $\mathrm{A}_{2 \mathrm{~B}} \mathrm{ARs}$ leads to a compensatory up-regulation of the other $\mathrm{AR}$ and thus, suggesting an interrelationship between these two receptor subtypes. Furthermore, we showed for the first time the involvement of non-mitochondrial $K_{\text {ATP }}$ channels in $\mathrm{A}_{2 \mathrm{~B}} \mathrm{AR}$-mediated coronary artery vasodilation, and finally showed the direct involvement of $\mathrm{K}_{\mathrm{ATP}}$ channels in $\mathrm{A}_{2 \mathrm{~A}} \mathrm{AR}$-mediated increase in coronary flow using $\mathrm{AR} \mathrm{KO}$ mice.

Adenosine's role in tissue protection may involve mechanisms such as increasing the tissue blood flow and protecting against ischemic damage (37). Adenosine is well known to play a vasoregulatory role in human coronary arteries (16-17, 62-63). We and others have previously also demonstrated the pivotal role for $\mathrm{A}_{2 \mathrm{~A}} \mathrm{AR}$ in $\mathrm{CF}$ regulation (5, $63,67,69)$. We also have preliminary data showing the involvement of $A_{2} A R$ in coronary reactive hyperemia that indirectly supports a physiological role for adenosine in CF regulation (data not shown) which is in support of previous in vivo and ex vivo reactive hyperemia studies $(5,12,77)$. Additionally, it is suggested that $A_{2 A} A R$ activation contributes to basal tone in coronary circulation through the release of nitric oxide (69). Our present data (Figure 5A) also support such a role for $\mathrm{A}_{2 \mathrm{~A}} \mathrm{AR}$ since SCH58261 $\left(A_{2 A} A R\right.$ selective antagonist) significantly reduced the baseline $C F$.

Due to its low affinity for adenosine, $A_{2 B} A R$ is known to be activated in conditions where a significant increase in adenosine levels is observed, such as in ischemic conditions (25). Therefore, $\mathrm{A}_{2 \mathrm{~B}} \mathrm{AR}$ may be more involved in pathophysiological 
conditions rather than physiological situations. However, cardiovascular effects of $\mathrm{A}_{2 \mathrm{~B}} \mathrm{AR}$ and its role in coronary vasodilation still remain to be fully elucidated. It was reported that $\mathrm{A}_{2 \mathrm{~B}} \mathrm{AR}$ plays a role in ischemia/reperfusion and preconditioning (15). Additionally, previous studies have used indirect measures such as non-selective agonist/antagonist (alloxazine), which is only about 10 fold more selective towards $A_{2 B} A R$ relative to $A_{2 A} A R(8)$, or $A_{2 A} K O$ mice (without the use of $A_{2 B}$ knockout) to indirectly study the role of $\mathrm{A}_{2 \mathrm{~B}} \mathrm{AR}$ in $\mathrm{CF}$ regulation $(48,67)$. In this study, we demonstrated the contribution of both $\mathrm{A}_{2 \mathrm{~A}}$ and $\mathrm{A}_{2 \mathrm{~B}} \mathrm{ARs}$ in coronary artery vasodilation where we further clarified the individual role of $A_{2 B} A R$ with the use of selective $A_{2 B} A R$ agonist BAY 60-6583 and $\mathrm{A}_{2 \mathrm{~B}} \mathrm{KO}$ mice (Figure 1). We also demonstrated that $\mathrm{A}_{2 \mathrm{~A}}$ and $\mathrm{A}_{2 \mathrm{~B}} \mathrm{ARs}$, out of all ARs, are involved in inducing coronary artery vasodilation with the use of $A_{2 A / 2 B} D K O$ mice (Figure 6). Reports suggesting that $A_{1}$ and $A_{3} A R s$ negatively modulate the role of $\mathrm{A}_{2 \mathrm{~A}}$ and $\mathrm{A}_{2 \mathrm{~B}} \mathrm{ARs}$ in $\mathrm{CF}$ regulation $(66,68)$ and the presence of only $\mathrm{A}_{2 \mathrm{~A}}$ and $\mathrm{A}_{2 \mathrm{~B}} \mathrm{ARs}$ on human and porcine coronary endothelial cells (53) may also indirectly support their involvement in coronary artery vasodilation.

Azakura et. al. suggested that the impairment of adenosine-related signaling contributes to the pathophysiology of congestive heart failure (2). In addition, we have previously demonstrated that $\mathrm{A}_{2 \mathrm{~A}} \mathrm{AR}$ is up-regulated in high-salt compared to normal-salt fed mice (51) and failure to up-regulate $\mathrm{A}_{2 \mathrm{~A}} \mathrm{AR}$-induced pathway contributes to the development of hypertension (44). Furthermore, few studies have shown that $\mathrm{A}_{2 \mathrm{~B}} \mathrm{AR}$ is selectively up-regulated in ischemic mouse hearts and by hypoxic conditions $(3,18)$ and differential expression of ARs contributes to functional heterogeneity of human endothelial cells (21). We have recently shown the up-regulation of $A_{2 B} A R$ in $A_{2 A} K O$ mice (69) and in this current study we demonstrated the up-regulation of $A_{2 A} A R$ in 
$\mathrm{A}_{2 \mathrm{~B}} \mathrm{KO}$ mice (Figures 2-5), suggesting the presence of a relationship between these two ARs. Therefore, further understanding of the relationship between $A_{2 A}$ and $A_{2 B} A R s$ may help us towards development of newer therapeutic approaches. Also, the observation that the down-regulation/deletion of $\mathrm{A}_{2 \mathrm{~A}}$ or $\mathrm{A}_{2 \mathrm{~B}} \mathrm{AR}$ leads to compensatory up-regulation of $\mathrm{A}_{2 \mathrm{~B}}$ and $\mathrm{A}_{2 \mathrm{~A}} \mathrm{AR}$, respectively, itself supports an important regulatory function for each of these AR subtypes. It is interesting to mention that this trend is observed in hypoxia of human umbilical vein endothelial and bronchial smooth muscle cells where hypoxia modulates the expression of $\mathrm{ARs}$ by decreasing $\mathrm{A}_{2 \mathrm{~A}} \mathrm{AR}$ mRNA but increasing $\mathrm{A}_{2 \mathrm{~B}} \mathrm{AR}$ mRNA levels (22). It is also noteworthy to mention that adenosine acts as a feed-back mediator in heart during hypertrophy and hypoxia (34) during which conditions other studies have shown the modification of ARs' expression $(2-3,18,22)$. These kinds of interactions have also been observed between other receptor subtypes such as adrenoceptors (ADR), where $\alpha_{1}$ ADR compensates for the down-regulation of $\beta A D R$ in pathological conditions such as cardiac remodeling (75).

Adenosine and its agonist are currently being used in clinical settings; The vasoregulatory properties of ARs are used clinically in humans for the diagnosis of coronary artery disease through the use of Adenosine (Adenoscan) as a substitute for exercise stress testing in myocardial perfusion imaging (7). The use of Adenoscan has its own limitations due to it blocking the AV conduction (due to activation of $\mathrm{A}_{1} \mathrm{AR}(4,7)$ ) and inducing bronchospasm (probably due to activation of $\mathrm{A}_{1}, \mathrm{~A}_{3}$ or $\mathrm{A}_{2 \mathrm{~B}} \mathrm{ARs}(24,59)$ ). However, these side effects may be alleviated by the development of more $\mathrm{A}_{2} \mathrm{AR}$ subtype selective agonists. A new $\mathrm{A}_{2 \mathrm{~A}} \mathrm{AR}$ selective agonist called Regadenoson (Lexiscan ${ }^{\circledR}$ ) has been developed and approved by FDA which is being used clinically in myocardial perfusion imaging. During this use of adenosine and its agonist in determining coronary 
reserve, the assessment of the true maximal dilatation of coronary arteries is an important factor (34). However, it is reported that maximal dilatation of coronary arteries with vasodilators such as adenosine does not eliminate all coronary vasomotor tone and that the role of hemodynamic changes should also be considered $(34,73)$. Nevertheless, the knowledge of the presence of a compensatory interaction between $\mathrm{A}_{2 \mathrm{~A}}$ and $\mathrm{A}_{2 \mathrm{~B}} \mathrm{ARs}$ may be helpful since most cardiac imagings are done in patients with vascular disease where the AR expression may have been already modified due to the disease condition. Furthermore, adenosine is being investigated as a treatment during percutaneous coronary intervention in order to reduce the myocardial reperfusion injury in patients with myocardial infarction (which is usually associated with worsening of cardiac injury and function). In these patients, intracoronary injection of adenosine is followed by a better myocardial salvage and thus prevention of left ventricular remodeling, ejection fraction, decreased infarct size, and ST-segment elevation resolution (10, 26, 46). However, Desmet et. al. demonstrated that adenosine significantly ameliorates ST-segment resolution while it does not improve myocardial salvage or coronary blood flow (11). Additionally, in another study, Ross et. al. showed a relationship between infarct size and primary clinical end point (death or heart failure) where adenosine significantly reduced the infarct size while, it did not improve the clinical outcome (61).

It is well known that arterioles, compared to coronary conduit arteries, are the major players in flow regulation and as previously reported, $\mathrm{A}_{2 \mathrm{~A}} \mathrm{AR}$ may be the major coronary artery vasodilator compared to $\mathrm{A}_{2 \mathrm{~B}} \mathrm{AR}$. Furthermore, large coronary arterioles were shown to be less responsive to adenosine than small ones and Hein et. al. have reported that mainly $\mathrm{A}_{2 \mathrm{~A}} \mathrm{ARs}$ are expressed in coronary arterioles $(32,42)$. The same disparity of receptor subtype distribution has also been seen with adrenoceptors, with 
adrenergic constriction of large arterioles being mediated by $\alpha_{1}$ while in terminal arterioles $\alpha_{2}$ exert this function (56). Additionally, in coronary arterioles, a greater $\alpha_{2}$ response has been shown compared to larger coronary arteries (70). Thus, showing the up-regulation of $\mathrm{A}_{2 \mathrm{~A}} \mathrm{AR}$ in $\mathrm{A}_{2 \mathrm{~B}} \mathrm{KO}$ mice would most likely not be reflected on larger coronary conduit arteries such as LAD. Isolation of mouse LAD and other large coronary conduit arteries is technically difficult but possible, however isolation of coronary resistance arterioles from mouse heart is almost impossible and to our knowledge no one has been able to isolate coronary arterioles so far which is a limitation in our study. However, $\mathrm{A}_{2 \mathrm{~A}} \mathrm{AR}$ protein expression in mouse mesenteric artery resistance vessels (up to third branch of arterioles) shows the up-regulation of $\mathrm{A}_{2 \mathrm{~A}} \mathrm{AR}$ in $\mathrm{A}_{2 \mathrm{~B}} \mathrm{KO}$ mice which confirms the compensatory up-regulation of $\mathrm{A}_{2 \mathrm{~A}} \mathrm{AR}$ in $\mathrm{A}_{2 \mathrm{~B}} \mathrm{KO}$ mice resistance vessels (Figure 3).

The occurrence of the up-regulatory mechanism phenomenon in our studies may be TNF- $\alpha$-induced and post-transcriptionally regulated (41) or due to DNA methylation since this may regulate AR cell surface expression levels (9). Furthermore, HIF-1 has also been suggested to up-regulate the expression of $A_{2 B} A R$ in hypoxic conditions (76). Although, the underlying mechanism may not be understood at this time, it seems that this relationship only exists between $\mathrm{A}_{2 \mathrm{~A}}$ and $\mathrm{A}_{2 \mathrm{~B}} \mathrm{ARs}$ and not between $\mathrm{A}_{1}$ or $\mathrm{A}_{3} \mathrm{ARs}$ since there was no significant difference between the concentration response curve for CCPA ( $\mathrm{A}_{1} \mathrm{AR}$ selective agonist) and Cl-IBMECA ( $\mathrm{A}_{3} \mathrm{AR}$ selective agonist $)$ in $\mathrm{A}_{2 \mathrm{~A} / 2 \mathrm{~B}} \mathrm{DKO}$ mice compared to WT (data not shown).

Potassium channels have been suggested to be involved in regulating blood flow and blood pressure and in AR signaling pathways $(29,49,78)$. For example, inward rectifier $\mathrm{K}^{+}\left(\mathrm{K}_{\mathrm{IR}}\right)$ channels may play a role since their presence has been reported on 
coronary artery smooth muscle cells (CASMCs) $(54,60,65)$, in addition, to their role as the dominant $\mathrm{K}^{+}$conductance in resting membrane potential (38). Moreover, adenosine is reported to activate ATP-sensitive potassium $\left(\mathrm{K}_{\mathrm{ATP}}\right)$ channels in rabbit mesenteric arteries and isolated CASMCs $(58,65)$. Others have demonstrated the presence of $\mathrm{K}_{\mathrm{ATP}}$ channels on coronary arteries and CASMCs $(28,65)$ and their role in $\mathrm{A}_{2 \mathrm{~A}}$-induced effect in reactive hyperemia and retinal microvessels dilation $(5,33,77)$. However there are no reports to our knowledge suggesting the involvement of $\mathrm{K}_{\mathrm{ATP}}$ channels in $\mathrm{A}_{2 \mathrm{~A}}$ and $\mathrm{A}_{2 \mathrm{~B}}$ ARs-induced changes in mouse $\mathrm{CF}$.

In this study, we used mitochondrial $\mathrm{K}_{\mathrm{ATP}}$ channel blocker, 5-hydroxydeconoate (5-HD) and glibenclamide to test $\mathrm{K}_{\mathrm{ATP}}$ channels involvement in $\mathrm{A}_{2 \mathrm{~A}}$ and $\mathrm{A}_{2 \mathrm{~B}} \mathrm{ARs}$-induced $\mathrm{CF}$ changes. Glibenclamide blocked the NECA-induced increase in $\mathrm{CF}$ in $\mathrm{A}_{2 \mathrm{~A}}$ and $\mathrm{A}_{2 \mathrm{~B}} \mathrm{KO}$ and BAY60-6583-, and CGS21680-induced increase in CF in WT mice. However, 5-HD had no effect on NECA-induced increase in CF, which may suggest a role for non-mitochondrial $\mathrm{K}_{\mathrm{ATP}}$ channels in both $\mathrm{A}_{2 \mathrm{~A}}$ and $\mathrm{A}_{2 \mathrm{~B}} \mathrm{ARs}$ signaling pathways (Figures 7-9A). However, this study does not show if the $\mathrm{K}_{\text {ATP }}$ channels are located on endothelial or SMCs. This is important since endothelial dysfunction is an early risk factor for cardiovascular diseases where a reduced adenosine response has been reported (19). Further, Wang et. al. suggested that activation of endothelial $\mathrm{K}_{\text {ATP }}$ channels might result in the protection against endothelial dysfunction (74). We think that adenosineinduced activation of $\mathrm{K}_{\mathrm{ATP}}$ channels may be indirectly through release of some other mediators such as hydrogen peroxide (27), which was previously suggested to be the endothelium-derived hyperpolarizing factor (47) and that may be involved in cardiovascular dysfunction (64). Elucidations of these signaling pathways will help us 
better understand the underlying cause of reduced adenosine response in cardiovascular diseases.

The availability of gene deleted knockout mice has been an important tool to dissect the physiological and pharmacological pathways for elucidating the role of a single receptor. However, in some instances, mice lacking a specific receptor gene exhibit phenotypic differences such as higher blood pressure in $\mathrm{A}_{2 \mathrm{~A}} \mathrm{KO}$ mice (43). Therefore, in this study we used both pharmacological and molecular (single and double gene knockout) approaches to confirm our results. We also evaluated the baseline parameters of WT and KO hearts (Table 1). The baseline LVDP of $\mathrm{A}_{2 \mathrm{~A} / 2 \mathrm{~B}} \mathrm{DKO}$ was significantly higher compared to WT, which may be attributed to alterations at second messenger or translational levels. The relationship between $\mathrm{A}_{2 \mathrm{~A}}$ and $\mathrm{A}_{2 \mathrm{~B}} \mathrm{ARs}$ and activation of other signaling pathways such as an increase in the levels of cAMP and $\mathrm{Ca}^{2+}$ may compensate for the deletion of $\mathrm{A}_{2 \mathrm{~A} / 2 \mathrm{~B}} \mathrm{ARs}(35,37)$. Even adrenoceptors may compensate for the absence of $\mathrm{A}_{2 \mathrm{~A}}$ and $\mathrm{A}_{2 \mathrm{~B}} \mathrm{ARs}$ since there are reports showing direct and indirect anti $\beta$-adrenergic effect of adenosine, suggesting the presence of an interaction between these two different GPCRs (49). Further experiments are required to better understand the relationship between these two receptor classes. There are no significant differences in baseline HR, LVDP, and CF of $\mathrm{A}_{2 \mathrm{~A}} \mathrm{KO}$ and $\mathrm{A}_{2 \mathrm{~B}} \mathrm{KO}$ mice compared to WT. We also tested the $\mathrm{A}_{2 \mathrm{~B}} \mathrm{KO}$ mice for endothelium functionality using bradykinin where we found no significant difference between the $\mathrm{A}_{2 \mathrm{~B}} \mathrm{KO}$ and WT groups, thus, showing the presence of a normal functional endothelium in $\mathrm{A}_{2 \mathrm{~B}} \mathrm{KO}$ (data not shown).

CGS21680 and NECA induced an increase in LVDP of WT and $\mathrm{A}_{2 \mathrm{~B}} \mathrm{KO}$ but not $\mathrm{A}_{2 \mathrm{~A} / 2 \mathrm{~B}} \mathrm{DKO}$. BAY60-6583 also induced an increase in LVDP of WT mice. These data support our previous report that $\mathrm{A}_{2 \mathrm{~A}}$ and $\mathrm{A}_{2 \mathrm{~B}} \mathrm{ARs}$ may be involved in cardiac contractility 
and positive inotropic effect (Figures 1, 2, and 4C) (69). Changes in CF can affect the contractility (Gregg effect) which is an inherent problem with the isolated perfused heart preparation. However, as shown in this study (Figures 2 and 6), the increase in CF comes earlier than the changes in LVDP which may suggest that the observed effects of $\mathrm{A}_{2} \mathrm{ARs}$ activation on LVDP may not be due to Gregg's effect. The opening of $\mathrm{K}_{\text {ATP }}$ channels may also affect the contractility independent of CF changes which may be independent of non-mitochondrial $\mathrm{K}_{\mathrm{ATP}}$ channels in this study since there is no difference observed in NECA-induced changes in LVDP in the presence of 5-HD (mitochondrial $\mathrm{K}_{\text {ATP }}$ channel blocker) while a significant decrease in NECA-induced changes in LVDP was shown in the presence of glibenclamide (non-selective $\mathrm{K}_{\mathrm{ATP}}$ channel blocker) (Figure 7). Additional studies are needed to define the role of $\mathrm{A}_{2} \mathrm{ARs}$ on LVDP. However, our data from $A_{2 \mathrm{~A} / 2 \mathrm{~B}} \mathrm{DKO}$ are very important since they show that only $\mathrm{A}_{2 \mathrm{~A}}$ and $\mathrm{A}_{2 \mathrm{~B}} \mathrm{ARs}$ are involved in LVDP and coronary vasodilation which could be further exploited for therapeutic approaches such as heart failure.

Our current study also confirms our previous finding that $\mathrm{A}_{1} \mathrm{AR}$ plays a role in HR (68) while $A_{2 A}$ and $A_{2 B} A R s$ do not since BAY60-6583 (Figure 1B) and CGS21680 (Figure 4B) did not affect HR while NECA (non-selective agonist) decreased the HR (Figure 2B). Additionally, our data showed a decrease in baseline HR in the presence of glibenclamide (Figures 7 and 9B) which could be due to the presence of $\mathrm{K}_{\text {ATP }}$ channels on atria and ventricle (79) and the $\mathrm{K}_{\mathrm{ATP}}$ channel-dependent potassium efflux-induced shortening of cardiac action potentials and hence a decrease in HR (79).

In conclusion, we showed for the first time, the individual role of $A_{2 B} A R$ and the contribution of $\mathrm{A}_{2 \mathrm{~A}} \mathrm{AR}$ in $\mathrm{A}_{2} \mathrm{ARs}$-mediated coronary vasodilation using $\mathrm{A}_{2 \mathrm{~B}} \mathrm{KO}$ and $\mathrm{A}_{2 \mathrm{~A} / 2 \mathrm{~B}} \mathrm{DKO}$ mice along with the use of $\mathrm{A}_{2 \mathrm{~B}} \mathrm{AR}$ and $\mathrm{A}_{2 \mathrm{~A}} \mathrm{AR}$ selective agonists. We found 
that $\mathrm{A}_{2 \mathrm{~A}}$ and $\mathrm{A}_{2 \mathrm{~B}} \mathrm{ARs}$ contribute to coronary artery vasodilation which involves $\mathrm{K}_{\mathrm{ATP}}$ channels and that $\mathrm{A}_{2 \mathrm{~A}} \mathrm{AR}$ is up-regulated in $\mathrm{A}_{2 \mathrm{~B}} \mathrm{KO}$ mice. These findings are another step toward a better understanding of ARs' pharmacology in coronary artery and the heterogeneity of CF responses by ARs which may lead to better therapeutic approaches for the treatment of cardiovascular disorders. 


\section{References}

1. Ansari HR, Nadeem A, Talukder MA, Sakhalkar S, and Mustafa SJ. Evidence for the involvement of nitric oxide in A2B receptor-mediated vasorelaxation of mouse aorta. Am J Physiol Heart Circ Physiol 292: H719-725, 2007. 2. Asakura M, Asanuma H, Kim J, Liao Y, Nakamaru K, Fujita M, Komamura K, Isomura T, Furukawa H, Tomoike H, and Kitakaze M. Impact of adenosine receptor signaling and metabolism on pathophysiology in patients with chronic heart failure. Hypertens Res 30: 781-787, 2007.

3. Ashton KJ, Nilsson U, Willems L, Holmgren K, and Headrick JP. Effects of aging and ischemia on adenosine receptor transcription in mouse myocardium. Biochem Biophys Res Commun 312: 367-372, 2003.

4. Bertolet BD, Belardinelli L, Franco EA, Nichols WW, Kerensky RA, and Hill JA. Selective attenuation by N-0861 (N6-endonorboran-2-yl-9-methyladenine) of cardiac A1 adenosine receptor-mediated effects in humans. Circulation 93: 1871$1876,1996$.

5. Berwick ZC, Payne GA, Lynch B, Dick GM, Sturek M, and Tune JD. Contribution of adenosine $\mathrm{A}(2 \mathrm{~A})$ and $\mathrm{A}(2 \mathrm{~B})$ receptors to ischemic coronary dilation: role of $\mathrm{K}(\mathrm{V})$ and $\mathrm{K}(\mathrm{ATP})$ channels. Microcirculation 17: 600-607.

6. Borea PA, Gessi S, Bar-Yehuda S, and Fishman P. A3 adenosine receptor: pharmacology and role in disease. Handb Exp Pharmacol: 297-327, 2009.

7. Botvinick EH. Current methods of pharmacologic stress testing and the potential advantages of new agents. J Nucl Med Technol 37: 14-25, 2009.

8. Brackett LE and Daly JW. Functional characterization of the A2b adenosine receptor in NIH 3 T3 fibroblasts. Biochem Pharmacol 47: 801-814, 1994. 
9. Buira SP, Albasanz JL, Dentesano G, Moreno J, Martin M, Ferrer I, and Barrachina M. DNA methylation regulates adenosine $\mathrm{A}(2 \mathrm{~A})$ receptor cell surface expression levels. J Neurochem 112: 1273-1285.

10. Claeys MJ, Bosmans J, De Ceuninck M, Beunis A, Vergauwen W, Vorlat A, and Vrints CJ. Effect of intracoronary adenosine infusion during coronary intervention on myocardial reperfusion injury in patients with acute myocardial infarction. Am J Cardiol 94: 9-13, 2004.

11. Desmet W, Bogaert J, Dubois C, Sinnaeve P, Adriaenssens T, Pappas C, Ganame J, Dymarkowski S, Janssens S, Belmans A, and Van de Werf F. High-dose intracoronary adenosine for myocardial salvage in patients with acute ST-segment elevation myocardial infarction. Eur Heart J 32: 867-877, 2011.

12. Dick GM, Bratz IN, Borbouse L, Payne GA, Dincer UD, Knudson JD, Rogers $\mathrm{PA}$, and Tune JD. Voltage-dependent $\mathrm{K}+$ channels regulate the duration of reactive hyperemia in the canine coronary circulation. Am J Physiol Heart Circ Physiol 294: H2371-2381, 2008.

13. Donoso MV, Lopez R, Miranda R, Briones R, and Huidobro-Toro JP. A2B adenosine receptor mediates human chorionic vasoconstriction and signals through arachidonic acid cascade. Am J Physiol Heart Circ Physiol 288: H2439-2449, 2005.

14. Eckle T, Faigle M, Grenz A, Laucher S, Thompson LF, and Eltzschig HK. A2B adenosine receptor dampens hypoxia-induced vascular leak. Blood 111: 20242035, 2008.

15. Eckle T, Kohler D, Lehmann R, El Kasmi K, and Eltzschig HK. Hypoxiainducible factor-1 is central to cardioprotection: a new paradigm for ischemic preconditioning. Circulation 118: 166-175, 2008. 
16. Edlund A, Conradsson T, and Sollevi A. A role for adenosine in coronary vasoregulation in man. Effects of theophylline and enprofylline. Clin Physiol 15: 623-636, 1995.

17. Edlund A and Sollevi A. Theophylline increases coronary vascular tone in humans: evidence for a role of endogenous adenosine in flow regulation. Acta Physiol Scand 155: 303-311, 1995.

18. Eltzschig HK, Ibla JC, Furuta GT, Leonard MO, Jacobson KA, Enjyoji K, Robson SC, and Colgan SP. Coordinated adenine nucleotide phosphohydrolysis and nucleoside signaling in posthypoxic endothelium: role of ectonucleotidases and adenosine A2B receptors. J Exp Med 198: 783-796, 2003.

19. Fahim M, Hussain T, and Mustafa SJ. Role of endothelium in adenosine receptor-mediated vasorelaxation in hypertensive rats. Fundam Clin Pharmacol 15: 325-334, 2001.

20. Feoktistov I and Biaggioni I. Adenosine A2B receptors. Pharmacol Rev 49: 381-402, 1997.

21. Feoktistov I, Goldstein AE, Ryzhov S, Zeng D, Belardinelli L, VoynoYasenetskaya T, and Biaggioni I. Differential expression of adenosine receptors in human endothelial cells: role of $\mathrm{A} 2 \mathrm{~B}$ receptors in angiogenic factor regulation. Circ Res 90: 531-538, 2002.

22. Feoktistov I, Ryzhov S, Zhong H, Goldstein AE, Matafonov A, Zeng D, and Biaggioni I. Hypoxia modulates adenosine receptors in human endothelial and smooth muscle cells toward an A2B angiogenic phenotype. Hypertension 44: 649654, 2004. 
23. Flood A and Headrick JP. Functional characterization of coronary vascular adenosine receptors in the mouse. Br J Pharmacol 133: 1063-1072, 2001.

24. Forsythe P, McGarvey LP, Heaney LG, MacMahon J, and Ennis M. Adenosine induces histamine release from human bronchoalveolar lavage mast cells. Clin Sci (Lond) 96: 349-355, 1999.

25. Fredholm BB. Adenosine, an endogenous distress signal, modulates tissue damage and repair. Cell Death Differ 14: 1315-1323, 2007.

26. Garratt KN, Holmes DR, Jr., Molina-Viamonte V, Reeder GS, Hodge DO, Bailey KR, Lobl JK, Laudon DA, and Gibbons RJ. Intravenous adenosine and lidocaine in patients with acute mycocardial infarction. Am Heart $J$ 136: 196-204, 1998.

27. Gebremedhin D, Weinberger B, Lourim D, and Harder DR. Adenosine can mediate its actions through generation of reactive oxygen species. J Cereb Blood Flow Metab 30: 1777-1790.

28. Glavind-Kristensen M, Matchkov V, Hansen VB, Forman A, Nilsson H, and Aalkjaer C. KATP-channel-induced vasodilation is modulated by the Na,K-pump activity in rabbit coronary small arteries. Br J Pharmacol 143: 872-880, 2004.

29. Haddy FJ, Vanhoutte PM, and Feletou M. Role of potassium in regulating blood flow and blood pressure. Am J Physiol Regul Integr Comp Physiol 290: R546$552,2006$.

30. Headrick JP and Lasley RD. Adenosine receptors and reperfusion injury of the heart. Handb Exp Pharmacol: 189-214, 2009. 
31. Heaps CL and Bowles DK. Gender-specific $K(+)$-channel contribution to adenosine-induced relaxation in coronary arterioles. J Appl Physiol 92: 550-558, 2002.

32. Hein TW, Wang W, Zoghi B, Muthuchamy M, and Kuo L. Functional and molecular characterization of receptor subtypes mediating coronary microvascular dilation to adenosine. J Mol Cell Cardiol 33: 271-282, 2001.

33. Hein TW, Yuan Z, Rosa RH, Jr., and Kuo L. Requisite roles of A2A receptors, nitric oxide, and KATP channels in retinal arteriolar dilation in response to adenosine. Invest Ophthalmol Vis Sci 46: 2113-2119, 2005.

34. Heusch G. Adenosine and maximum coronary vasodilation in humans: myth and misconceptions in the assessment of coronary reserve. Basic Res Cardiol 105: 1$5,2010$.

35. Hove-Madsen L, Prat-Vidal C, Llach A, Ciruela F, Casado V, Lluis C, BayesGenis A, Cinca J, and Franco R. Adenosine A2A receptors are expressed in human atrial myocytes and modulate spontaneous sarcoplasmic reticulum calcium release. Cardiovasc Res 72: 292-302, 2006.

36. Iwamoto T, Umemura S, Toya Y, Uchibori T, Kogi K, Takagi N, and Ishii M. Identification of adenosine A2 receptor-cAMP system in human aortic endothelial cells. Biochem Biophys Res Commun 199: 905-910, 1994.

37. Jacobson KA and Gao ZG. Adenosine receptors as therapeutic targets. Nat Rev Drug Discov 5: 247-264, 2006.

38. Johnson TD, Marrelli SP, Steenberg ML, Childres WF, and Bryan RM, Jr. Inward rectifier potassium channels in the rat middle cerebral artery. Am $\mathrm{J}$ Physiol 274: R541-547, 1998. 
39. Kemp BK and Cocks TM. Adenosine mediates relaxation of human small resistance-like coronary arteries via A2B receptors. Br J Pharmacol 126: 1796-1800, 1999.

40. Kerbaul F, Benard F, Giorgi R, Youlet B, Carrega L, Zouher I, Mercier L, Gerolami V, Benas V, Blayac D, Gariboldi V, Collart F, and Guieu R. Adenosine A2A receptor hyperexpression in patients with severe SIRS after cardiopulmonary bypass. J Investig Med 56: 864-871, 2008.

41. Kolachala VL, Wang L, Obertone TS, Prasad M, Yan Y, Dalmasso G, Gewirtz AT, Merlin D, and Sitaraman SV. Adenosine 2B receptor expression is post-transcriptionally regulated by microRNA. J Biol Chem 285: 18184-18190.

42. Kuo L, Davis MJ, and Chilian WM. Longitudinal gradients for endotheliumdependent and -independent vascular responses in the coronary microcirculation. Circulation 92: 518-525, 1995.

43. Ledent C, Vaugeois JM, Schiffmann SN, Pedrazzini T, El Yacoubi M, Vanderhaeghen JJ, Costentin J, Heath JK, Vassart G, and Parmentier M. Aggressiveness, hypoalgesia and high blood pressure in mice lacking the adenosine A2a receptor. Nature 388: 674-678, 1997.

44. Liclican EL, McGiff JC, Falck JR, and Carroll MA. Failure to upregulate the adenosine2A receptor-epoxyeicosatrienoic acid pathway contributes to the development of hypertension in Dahl salt-sensitive rats. Am J Physiol Renal Physiol 295: F1696-1704, 2008.

45. Marala RB and Mustafa SJ. Immunological characterization of adenosine A2A receptors in human and porcine cardiovascular tissues. J Pharmacol Exp Ther 286: 1051-1057, 1998. 
46. Marzilli M, Orsini E, Marraccini P, and Testa R. Beneficial effects of intracoronary adenosine as an adjunct to primary angioplasty in acute myocardial infarction. Circulation 101: 2154-2159, 2000.

47. Matoba T, Shimokawa H, Morikawa K, Kubota H, Kunihiro I, UrakamiHarasawa L, Mukai Y, Hirakawa Y, Akaike T, and Takeshita A. Electron spin resonance detection of hydrogen peroxide as an endothelium-derived hyperpolarizing factor in porcine coronary microvessels. Arterioscler Thromb Vasc Biol 23: 1224-1230, 2003.

48. Morrison RR, Talukder MA, Ledent C, and Mustafa SJ. Cardiac effects of adenosine in $\mathrm{A}(2 \mathrm{~A})$ receptor knockout hearts: uncovering $\mathrm{A}(2 \mathrm{~B})$ receptors. $\mathrm{Am} J$ Physiol Heart Circ Physiol 282: H437-444, 2002.

49. Mustafa SJ, Morrison RR, Teng B, and Pelleg A. Adenosine receptors and the heart: role in regulation of coronary blood flow and cardiac electrophysiology. Handb Exp Pharmacol: 161-188, 2009.

50. Nayeem MA, Poloyac SM, Falck JR, Zeldin DC, Ledent C, Ponnoth DS, Ansari HR, and Mustafa SJ. Role of CYP epoxygenases in A2A AR-mediated relaxation using A2A AR-null and wild-type mice. Am J Physiol Heart Circ Physiol 295: H2068-2078, 2008.

51. Nayeem MA, Ponnoth DS, Boegehold MA, Zeldin DC, Falck JR, and Mustafa SJ. High-salt diet enhances mouse aortic relaxation through adenosine A2A receptor via CYP epoxygenases. Am J Physiol Regul Integr Comp Physiol 296: R567$574,2009$. 
52. Olanrewaju HA, Gafurov BS, and Lieberman EM. Involvement of K+ channels in adenosine $\mathrm{A} 2 \mathrm{~A}$ and $\mathrm{A} 2 \mathrm{~B}$ receptor-mediated hyperpolarization of porcine coronary artery endothelial cells. J Cardiovasc Pharmacol 40: 43-49, 2002.

53. Olanrewaju HA, Qin W, Feoktistov I, Scemama JL, and Mustafa SJ. Adenosine $\mathrm{A}(2 \mathrm{~A})$ and $\mathrm{A}(\mathrm{2B})$ receptors in cultured human and porcine coronary artery endothelial cells. Am J Physiol Heart Circ Physiol 279: H650-656, 2000.

54. Park WS, Han J, Kim N, Ko JH, Kim SJ, and Earm YE. Activation of inward rectifier $\mathrm{K}+$ channels by hypoxia in rabbit coronary arterial smooth muscle cells. Am J Physiol Heart Circ Physiol 289: H2461-2467, 2005.

55. Pich EM and Epping-Jordan MP. Transgenic mice in drug dependence research. Ann Med 30: 390-396, 1998.

56. Pohl U, De Wit C, and Gloe T. Large arterioles in the control of blood flow: role of endothelium-dependent dilation. Acta Physiol Scand 168: 505-510, 2000.

57. Ponnoth DS, Sanjani MS, Ledent C, Roush K, Krahn T, and Mustafa SJ. Absence of adenosine-mediated aortic relaxation in $\mathrm{A}(2 \mathrm{~A})$ adenosine receptor knockout mice. Am J Physiol Heart Circ Physiol 297: H1655-1660, 2009.

58. Quayle JM, Bonev AD, Brayden JE, and Nelson MT. Pharmacology of ATPsensitive $\mathrm{K}+$ currents in smooth muscle cells from rabbit mesenteric artery. Am $J$ Physiol 269: C1112-1118, 1995.

59. Ramkumar V, Stiles GL, Beaven MA, and Ali H. The A3 adenosine receptor is the unique adenosine receptor which facilitates release of allergic mediators in mast cells. J Biol Chem 268: 16887-16890, 1993. 
60. Rivers RJ, Hein TW, Zhang C, and Kuo L. Activation of barium-sensitive inward rectifier potassium channels mediates remote dilation of coronary arterioles. Circulation 104: 1749-1753, 2001.

61. Ross AM, Gibbons RJ, Stone GW, Kloner RA, and Alexander RW. A randomized, double-blinded, placebo-controlled multicenter trial of adenosine as an adjunct to reperfusion in the treatment of acute myocardial infarction (AMISTADII). J Am Coll Cardiol 45: 1775-1780, 2005.

62. Sabouni MH, Ramagopal MV, and Mustafa SJ. Relaxation by adenosine and its analogs of potassium-contracted human coronary arteries. Naunyn Schmiedebergs Arch Pharmacol 341: 388-390, 1990.

63. Sato A, Terata K, Miura H, Toyama K, Loberiza FR, Jr., Hatoum OA, Saito T, Sakuma I, and Gutterman DD. Mechanism of vasodilation to adenosine in coronary arterioles from patients with heart disease. Am J Physiol Heart Circ Physiol 288: H1633-1640, 2005.

64. Sousa T, Pinho D, Morato M, Marques-Lopes J, Fernandes E, Afonso J, Oliveira S, Carvalho F, and Albino-Teixeira A. Role of superoxide and hydrogen peroxide in hypertension induced by an antagonist of adenosine receptors. Eur $J$ Pharmacol 588: 267-276, 2008.

65. Sun Park W, Kyoung Son Y, Kim N, Boum Youm J, Joo H, Warda M, Ko JH, Earm YE, and Han J. The protein kinase A inhibitor, H-89, directly inhibits KATP and Kir channels in rabbit coronary arterial smooth muscle cells. Biochem Biophys Res Commun 340: 1104-1110, 2006.

66. Talukder MA, Morrison RR, Jacobson MA, Jacobson KA, Ledent C, and Mustafa SJ. Targeted deletion of adenosine $\mathrm{A}(3)$ receptors augments adenosine- 
induced coronary flow in isolated mouse heart. Am J Physiol Heart Circ Physiol 282: H2183-2189, 2002.

67. Talukder MA, Morrison RR, Ledent C, and Mustafa SJ. Endogenous adenosine increases coronary flow by activation of both $\mathrm{A} 2 \mathrm{~A}$ and $\mathrm{A2B}$ receptors in mice. J Cardiovasc Pharmacol 41: 562-570, 2003.

68. Tawfik HE, Teng B, Morrison RR, Schnermann J, and Mustafa SJ. Role of A1 adenosine receptor in the regulation of coronary flow. Am J Physiol Heart Circ Physiol 291: H467-472, 2006.

69. Teng B, Ledent $C$, and Mustafa SJ. Up-regulation of A $2 B$ adenosine receptor in A $2 \mathrm{~A}$ adenosine receptor knockout mouse coronary artery. J Mol Cell Cardiol 44: 905-914, 2008.

70. Teng B and Muir WW, 3rd. Effects of xylazine on canine coronary artery vascular rings. Am J Vet Res 65: 431-435, 2004.

71. Teng B, Qin W, Ansari HR, and Mustafa SJ. Involvement of p38-mitogenactivated protein kinase in adenosine receptor-mediated relaxation of coronary artery. Am J Physiol Heart Circ Physiol 288: H2574-2580, 2005.

72. Ueeda M, Thompson RD, Padgett WL, Secunda S, Daly JW, and Olsson RA. Cardiovascular actions of adenosines, but not adenosine receptors, differ in rat and guinea pig. Life Sci 49: 1351-1358, 1991.

73. van de Hoef TP, Nolte F, Rolandi MC, Piek JJ, van den Wijngaard JP, Spaan JA, and Siebes M. Coronary pressure-flow relations as basis for the understanding of coronary physiology. J Mol Cell Cardiol, 2011. 
74. Wang H, Long C, Duan Z, Shi C, Jia G, and Zhang Y. A new ATP-sensitive potassium channel opener protects endothelial function in cultured aortic endothelial cells. Cardiovasc Res 73: 497-503, 2007.

75. Woodcock EA, Du XJ, Reichelt ME, and Graham RM. Cardiac alpha 1adrenergic drive in pathological remodelling. Cardiovasc Res 77: 452-462, 2008.

76. Yang M, Ma C, Liu S, Shao Q, Gao W, Song B, Sun J, Xie Q, Zhang Y, Feng A, Liu Y, Hu W, and Qu X. HIF-dependent induction of adenosine receptor A2b skews human dendritic cells to a Th2-stimulating phenotype under hypoxia. Immunol Cell Biol 88: 165-171.

77. Zatta AJ and Headrick JP. Mediators of coronary reactive hyperaemia in isolated mouse heart. Br J Pharmacol 144: 576-587, 2005.

78. Zhao JL, Yang YJ, Pei WD, Sun YH, Chen JL, and Go RL. Intravenous adenosine reduces myocardial no-reflow by decreasing endothelin-1 via activation of the ATP-sensitive K+ channel. Acta Cardiol 63: 355-359, 2008.

79. Zingman LV, Zhu Z, Sierra A, Stepniak E, Burnett CM, Maksymov G, Anderson ME, Coetzee WA, and Hodgson-Zingman DM. Exercise-induced expression of cardiac ATP-sensitive potassium channels promotes action potential shortening and energy conservation. J Mol Cell Cardiol 51: 72-81, 2011. 


\section{CHAPTER FOUR}

Interactions between $\mathrm{A}_{2 \mathrm{~A}}$ adenosine receptor, hydrogen peroxide, and $\mathrm{K}^{+}$-ATP channel in coronary reactive hyperemia 


\begin{abstract}
Myocardial metabolites such as adenosine mediate reactive hyperemia (RH), partially, by activating ATP-dependent $\mathrm{K}^{+}\left(\mathrm{K}_{\mathrm{ATP}}\right)$ channels in coronary smooth muscle. In this study, we investigated the role of $\mathrm{A}_{2}$ adenosine receptors (ARs) and their downstream signaling mechanisms in $\mathrm{RH}$. We tested the hypothesis that coronary $\mathrm{RH}$ involves $\mathrm{A}_{2 \mathrm{~A}} \mathrm{ARs}$, hydrogen peroxide $\left(\mathrm{H}_{2} \mathrm{O}_{2}\right)$, and $\mathrm{K}_{\mathrm{ATP}}$ channels using $\mathrm{A}_{2 \mathrm{~A}}$ and $\mathrm{A}_{2 \mathrm{~B}}$ single $(\mathrm{KO})$ and $\mathrm{A}_{2 \mathrm{~A} / 2 \mathrm{~B}}$ double knockout (DKO) mice hearts in a Langendorff heart. Flow debt-to-repayment ratio (RPA//DA) following a $15 \mathrm{~s}$ occlusion was $1.3 \pm 0.1$ in WT which was reduced in hearts from $\mathrm{A}_{2 \mathrm{~A}} \mathrm{KO}(0.9 \pm 0.1)$, but not $\mathrm{A}_{2 \mathrm{~B}} \mathrm{KO}(1.2 \pm 0.1)$ mice. Catalase $(1250 \mathrm{U} / \mathrm{ml})$, an enzyme that breaks down $\mathrm{H}_{2} \mathrm{O}_{2}$, significantly reduced the baseline flow $(\mathrm{ml} / \mathrm{min} / \mathrm{g})$ in $\mathrm{A}_{2 \mathrm{~A}} \mathrm{KO}$ hearts (16.8 \pm 0.9$)$ compared with control (19.4 \pm 1.6$)$ and WT in the presence and absence of catalase (21.4 \pm 2.1 and $19.8 \pm 0.9$, respectively). However, catalase significantly reduced the RPA/DA in WT $(0.8 \pm 0.1)$ but, not in $\mathrm{A}_{2 \mathrm{~A}} \mathrm{KO}$ $(0.9 \pm 0.1)$ mice compared with its control. Patch clamp experiments demonstrated that adenosine $(10 \mu \mathrm{M})$ activated a glibenclamide $\left(10 \mu \mathrm{M} ; \mathrm{K}_{\mathrm{ATP}}\right.$ channel blocker)-sensitive conductance $(\mathrm{nS} / \mathrm{pF})$ in smooth muscle cells from WT $(0.048 \pm 0.01)$ but not $\mathrm{A}_{2 \mathrm{~A}} / \mathrm{A}_{2 \mathrm{~B}} \mathrm{DKO}(0.016 \pm 0.01)$ mice. Importantly, however, conductance activated by pinacidil (10 $\mu \mathrm{M}$; a $\mathrm{K}_{\mathrm{ATP}}$ channel opener) was similar in cells from $\mathrm{WT}$ and $\mathrm{A}_{2 \mathrm{~A}} / \mathrm{A}_{2 \mathrm{~B}} \mathrm{DKO}$ mice $(0.013 \pm 0.034$ vs. $0.012 \pm 0.04 \mathrm{nS} / \mathrm{pF})$. Additionally, in WT smooth muscle cells, $\mathrm{H}_{2} \mathrm{O}_{2}(1 \mathrm{mmol} / \mathrm{L})$ activated a glibenclamide-sensitive conductance $(0.074 \pm 0.02 \mathrm{nS} / \mathrm{pF})$. Our data indicate that $\mathrm{A}_{2 \mathrm{~A}} \mathrm{ARs}$ are coupled to $\mathrm{K}_{\mathrm{ATP}}$ channels in $\mathrm{RH}$, in part, via the production of $\mathrm{H}_{2} \mathrm{O}_{2}$ as a signaling intermediate.
\end{abstract}

Keywords: coronary circulation, ischemic vasodilation, adenosine receptors, knockout mice, reactive oxygen species 


\section{Introduction}

The heart responds to acute ischemia by transiently increasing blood flow in a phenomenon called reactive hyperemia (RH) (7). The temporary reduction in coronary vascular resistance is mediated by chemical signals released into blood (47), including adenosine (44). Adenosine induces its effects through activation of its receptors (AR) namely $A_{1}, A_{2 A}, A_{2 B}$, and $\mathrm{A}_{3}$. Adenosine's cardiovascular effects depend on the activation of the subtype of receptor involved, where $\mathrm{A}_{2} \mathrm{ARs}$ are known to play a role in coronary vasodilation through their action on both endothelial and smooth muscle cells. Our laboratory and others have shown that $\mathrm{A}_{2 \mathrm{~A}} \mathrm{ARs}$ play a pivotal role in the regulation of coronary flow $(\mathrm{CF})(48,50)$, while, $\mathrm{A}_{2 \mathrm{~B}} \mathrm{ARs}$ are also involved, albeit with a lesser contribution compared to $\mathrm{A}_{2 \mathrm{~A}} \mathrm{ARs}(32,48,50)$. Additionally, pharmacological studies indicate that $\mathrm{A}_{2 \mathrm{~A}}$ and $\mathrm{A}_{2 \mathrm{~B}} \mathrm{ARs}$ are the subtypes most likely involved in coronary RH $(2,11,62)$. However, undesirable overlap in the pharmacological profiles of adenosine receptor antagonists obfuscates the relative contribution of $A_{2 A}$ and $A_{2 B} A R s$ in $R H$. Thus, in order to more specifically determine the roles of $A_{2 \mathrm{~A}}$ and $\mathrm{A}_{2 \mathrm{~B}} \mathrm{ARs}$ in coronary $\mathrm{RH}$, we used Langendorff-perfused hearts from wild type (WT) and $\mathrm{A}_{2 \mathrm{~A}}, \mathrm{~A}_{2 \mathrm{~B}}$ knockout (KO) and $\mathrm{A}_{2 \mathrm{~A}}$ and $\mathrm{A}_{2 \mathrm{~B}}$ double knockout $(\mathrm{DKO})$ mice.

Numerous mediators and end effectors of coronary RH have been proposed. Importantly, however, information remains scarce regarding the role of $\mathrm{H}_{2} \mathrm{O}_{2}$, a coronary metabolic and endothelium-dependent vasodilator $(29,45,58)$, and its interactions with ARs and $\mathrm{K}_{\mathrm{ATP}}$ channels. Some support for $\mathrm{H}_{2} \mathrm{O}_{2}$ in $\mathrm{RH}$ has been provided by studies of skeletal muscle and isolated coronary arterioles $(3,20)$. The idea that $\mathrm{K}_{\mathrm{ATP}}$ channels participate in coronary $\mathrm{RH}$ is well established $(1,12)$, but it is unknown whether $\mathrm{H}_{2} \mathrm{O}_{2}$ couples adenosine receptor activation to $\mathrm{K}_{\text {ATP }}$ channel activity. $\mathrm{K}_{\text {ATP }}$ channels are known to mediate, at least in part, $\mathrm{H}_{2} \mathrm{O}_{2}$-induced dilatation of arterioles from skeletal muscle and brain $(25,55)$ and cardiac myocytes $(18)$. However, to our knowledge, direct evidence of this mechanism in smooth muscle is still to be elucidated. Thus, we 
ascertained whether $\mathrm{H}_{2} \mathrm{O}_{2}$ is involved in coronary $\mathrm{RH}$ and whether $\mathrm{H}_{2} \mathrm{O}_{2}$ mediates the coupling of adenosine receptors to activation of $\mathrm{K}_{\mathrm{ATP}}$ in coronary $\mathrm{RH}$.

\section{Materials and Methods}

Animals. An Institutional Animal Care and Use Committee at West Virginia University School of Medicine approved all experimental protocols. We followed guidelines set forth by the American Physiological Society and National Institutes of Health regarding the care and use of laboratory animals. $\mathrm{A}_{2 \mathrm{~A}}$ and $\mathrm{A}_{2 \mathrm{~B}}$ knockout mice, both backcrossed 12 generations to the WT C57BL/6 background (Jackson Laboratory; Bar Harbor, ME), were bred to generate $A_{2 A} / A_{2 B}$ double heterozygotes. Double heterozygotes were intercrossed, 1/16 of the offspring were $\mathrm{A}_{2 \mathrm{~A}} / \mathrm{A}_{2 \mathrm{~B}}$ double knockouts, and $\mathrm{A}_{2 \mathrm{~A}} / \mathrm{A}_{2 \mathrm{~B}}$ knockout breeding pairs were established. Mice were caged in a 12:12-hr light-dark cycle with free access to standard chow and water.

WT, $A_{2 A}$, and $A_{2 B} K O$ and $A_{2 A / 2 B} D K O$ mice. WT mice of a mixed C57/BL6 genetic background were purchased from The Jackson Laboratory (Bar Harbor, Maine). All four WT, $\mathrm{A}_{2 \mathrm{~A}} \mathrm{KO}, \mathrm{A}_{2 \mathrm{~B}} \mathrm{KO}$, and $\mathrm{A}_{2 \mathrm{~A} / 2 \mathrm{~B}} \mathrm{DKO}$ strains were bred at the West Virginia University animal facility as a sub-colony of the original strain. All animal care and experimentation were in accordance with the West Virginia University Institutional Animal Care and Use Committee and the principles of the National Institutes of Health "Guide for the Care and Use of Laboratory Animals."

Langendorff-perfusion. Mice (10-14 wks of age) were anesthetized with sodium pentobarbital (50 mg/kg i.p.) and hearts were excised into heparinized (5 U/ml) ice-cold KrebsHenseleit (KH) buffer. KH contained (mmol/L) $119 \mathrm{NaCl}, 11$ glucose, $22 \mathrm{NaHCO}_{3}, 4.7 \mathrm{KCl}, 1.2$ $\mathrm{KH}_{2} \mathrm{PO}_{4}, 1.2 \mathrm{MgSO}_{4}, 2.5 \mathrm{CaCl}_{2}, 2$ pyruvate and 0.5 EDTA. Hearts beat spontaneously when retrogradely perfused $(80 \mathrm{mmHg})$ with $37^{\circ} \mathrm{C} \mathrm{KH}$ bubbled with $95 \% \mathrm{O}_{2}$ and $5 \% \mathrm{CO}_{2}$. The left atrium was removed and the left ventricle drained. A fluid-filled balloon was inserted into the left ventricle and connected to a transducer for pressure measurements. Left ventricular diastolic 
pressure was adjusted to $2-5 \mathrm{mmHg}$. Coronary flow was measured with a probe (Transonic Systems; Ithaca, NY) in the aortic perfusion line. Hearts were paced to 400 beats/min and function allowed to stabilize. Hearts with persistent arrhythmias or developed pressure less than $80 \mathrm{mmHg}$ were excluded from the study. Baseline coronary flow and cardiac function were measured using a Power Lab data acquisition system (AD Instruments; Colorado Springs, CO). Hearts were then subjected to 15 seconds of total flow occlusion to elicit hyperemia. Catalase (Sigma Chemical Co.; St. Louis, MO) was delivered into the aortic perfusion line using a microinjection pump (Harvard Apparatus; Holliston, MA) as 1\% of coronary flow to achieve a final concentration of $1250 \mathrm{U} / \mathrm{ml}(57,60)$.

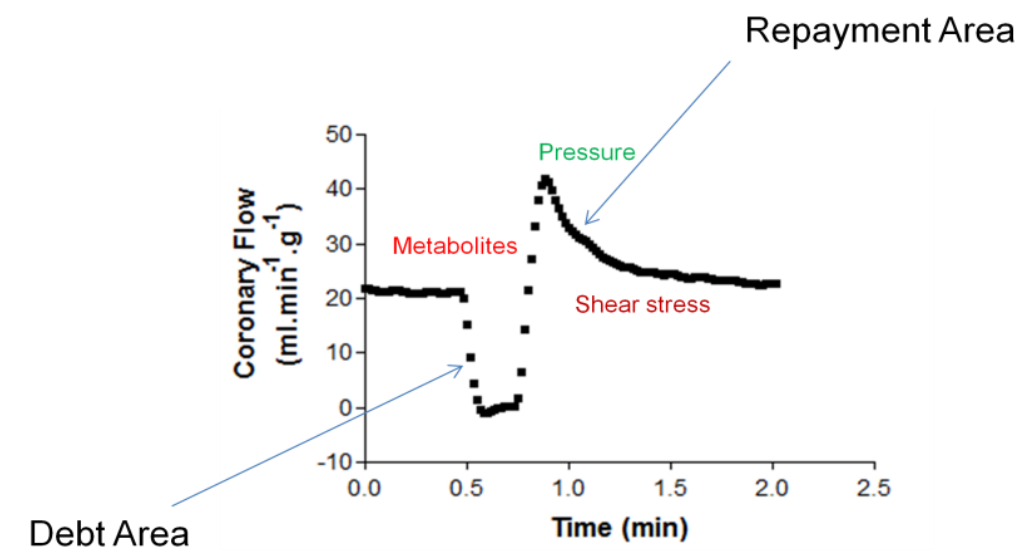

Patch clamp. Single smooth muscle cells were enzymatically isolated from the aortas of WT and $A_{2 A} / A_{2 B}$ knockout mice. For cell isolation, a simple HEPES-buffered saline was used and contained (mmol/L) $135 \mathrm{NaCl}, 5 \mathrm{KCl}, 1 \mathrm{MgCl}_{2}, 0.36 \mathrm{CaCl}_{2}, 10$ glucose, 10 HEPES, and 5 Tris; $\mathrm{pH}$ 7.4. The aorta was placed in this solution plus $(\mathrm{mg} / \mathrm{ml}) 2$ collagenase, 1 elastase, 2 bovine serum albumin, and 1 soybean trypsin inhibitor for $15 \mathrm{~min}$ at $37^{\circ} \mathrm{C}$. The tissue was passed through the tip of a fire-polished Pasteur pipette to liberate single cells. Smooth muscle cells were pelleted at $0.5 \mathrm{~g}$, resuspended in enzyme-free buffer, placed on ice, and used within $8 \mathrm{hr}$. Cells were placed in a recording chamber atop an inverted microscope and perfused with a HEPESbuffered solution (as above) containing $140 \mathrm{mmol} / \mathrm{L} \mathrm{K}^{+}$. Patch pipettes (3-5 MOhms) were filled with this $140 \mathrm{mmol} / \mathrm{L} \mathrm{K}^{+}$solution supplemented with $5 \mathrm{mmol} / \mathrm{L} \mathrm{Mg}$-ATP and $0.1 \mathrm{mM} \mathrm{Na}-\mathrm{GTP}$; 
$\mathrm{pH}$ 7.1. Inward $\mathrm{K}_{\mathrm{ATP}}$ currents were recorded in the conventional whole-cell mode (with Nernst equilibrium potential for $\mathrm{K}^{+}$set to $0 \mathrm{mV}$ ). The membrane potential was held at -80 and ramped or stepped to potentials between -100 and $+100 \mathrm{mV}$. Currents were low-pass filtered a $1 \mathrm{kHz}$ and digitized at $5 \mathrm{kHz}$. Series resistance and whole-cell capacitance were compensated as completely as possible using circuitry of the amplifier (PC-505, Warner Instruments; Hamden, CT). This amplifier was interfaced to a computer with pClamp 9 software for data acquisition and analysis (Molecular Devices; Sunnyvale, CA).

Statistical analysis. Statistical analyses were made with $t$-test and one- or two-way analysis of variance (ANOVA) with post hoc tests as indicated. Results were considered significant when $P<0.05$. Values are means \pm SEM from $n$ number of animals.

\section{Results}

Involvement of $A_{2 A} A R s$ in coronary reactive hyperemia. We used $\mathrm{WT}$ and $\mathrm{A}_{2 \mathrm{~A}} \mathrm{KO}$ mice in order to test the involvement of $\mathrm{A}_{2 \mathrm{~A}} \mathrm{ARs}$ in coronary $\mathrm{RH}$. The flow debt-to-repayment ratio was significantly reduced in $\mathrm{A}_{2 \mathrm{~A}} \mathrm{KO}(0.9 \pm 0.1, \mathrm{n}=8)$ compared with WT $(1.3 \pm 0.1, \mathrm{n}=6)$ mice (Figure 1B) while, the peak flow was not different between the two groups (WT: $42.7 \pm 2 \mathrm{ml} / \mathrm{min} / \mathrm{g}, \mathrm{n}=6$ vs. $\mathrm{A}_{2 \mathrm{~A}} \mathrm{KO}: 42.9 \pm 1.7 \mathrm{ml} / \mathrm{min} / \mathrm{g}, \mathrm{n}=8$, Figure $\left.1 \mathrm{C}\right)$. The resting flow of $19.4 \pm 1.6 \mathrm{ml} / \mathrm{min} / \mathrm{g}(\mathrm{n}=8)$ in $\mathrm{A}_{2 \mathrm{~A}} \mathrm{KO}$ was similar to WT $(19.8 \pm 0.9 \mathrm{ml} / \mathrm{min} / \mathrm{g}, \mathrm{n}=6$, Table 1$)$.

$A_{2 B} A R s$ may not be involved in coronary reactive hyperemia. In order to characterize the role of $\mathrm{A}_{2 \mathrm{~B}} \mathrm{ARs}$ in coronary $\mathrm{RH}$, we performed our $\mathrm{RH}$ experiments in WT and $\mathrm{A}_{2 \mathrm{~B}} \mathrm{KO}$ mice. The flow debt-to-repayment ratio (Figure 2B) and peak flow (Figure 2C) in $\mathrm{A}_{2 \mathrm{~B}} \mathrm{KO}, 1.2 \pm 0.1$ and $44.2 \pm 0.5 \mathrm{ml} / \mathrm{min} / \mathrm{g}(\mathrm{n}=4)$, respectively, were not different compared with WT, $1.3 \pm 0.1$ and $42.7 \pm 2$ $\mathrm{ml} / \mathrm{min} / \mathrm{g}(\mathrm{n}=6)$, respectively. Additionally, the resting flow of $\mathrm{A}_{2 \mathrm{~B}} \mathrm{KO}, 20.3 \pm 1.1 \mathrm{ml} / \mathrm{min} / \mathrm{g}$ was not different compared with WT, $19.8 \pm 0.9 \mathrm{ml} / \mathrm{min} / \mathrm{g}$, respectively (Table 1).

Involvement of only $A_{2} A R s$ in coronary reactive hyperemia. Since we have previously shown that only $A_{2 A}$ and $A_{2 B} A R s$, out of four ARs, are involved in the regulation of $C F$ (48), we 
tested the involvement of other ARs than $\mathrm{A}_{2} \mathrm{ARs}$ in coronary $\mathrm{RH}$ using $\mathrm{WT}$ and $\mathrm{A}_{2 \mathrm{~A} / 2 \mathrm{~B}} \mathrm{DKO}$ mice. The flow debt-to-repayment ratio was significantly higher in WT $(1.3 \pm 0.1, n=6)$ compared with $\mathrm{A}_{2 \mathrm{~A} / 2 \mathrm{~B}} \mathrm{DKO}(1 \pm 0.1, \mathrm{n}=8)$ mice (Figure $\left.3 \mathrm{~B}\right)$, which may be only due to the absence of $\mathrm{A}_{2 \mathrm{~A}} \mathrm{ARs}$, nevertheless, the peak flow was not different between the two groups, $42.7 \pm 2 \mathrm{ml} / \mathrm{min} / \mathrm{g}$ and $41.6 \pm 1.2 \mathrm{ml} / \mathrm{min} / \mathrm{g}$, respectively (Figure $3 \mathrm{C}$ ). Additionally, the resting flow of $\mathrm{A}_{2 \mathrm{~A} / 2 \mathrm{~B}} \mathrm{DKO}$, 18.6 $\pm 0.6 \mathrm{ml} / \mathrm{min} / \mathrm{g}(\mathrm{n}=8)$ was not different compared with WT (Table 1).

Adenosine activates $K_{\text {ATP }}$ channels. It is known that $\mathrm{K}_{\mathrm{ATP}}$ channels play a role in coronary RH $(2,62)$. We have also previously reported that both $A_{2 A}$ and $A_{2 B}$ ARs induce coronary vasodilation, and hence an increase in $\mathrm{CF}$, through activation of $\mathrm{K}_{\mathrm{ATP}}$ channels (48). We established this finding by using our isolated heart system (48). However, in this study we wanted to investigate this finding on a molecular level using patch clamp. Since both $A_{2 A}$ and $A_{2 B} A R s$ were shown to activate $\mathrm{K}_{\mathrm{ATP}}$ channels, in this study, we used $\mathrm{A}_{2 \mathrm{~A} / 2 \mathrm{~B}} \mathrm{DKO}$ mice in order to be able to distinguish the currents activated due to activation of ARs. Adenosine $(10 \mu \mathrm{mol} / \mathrm{L})$ activated a conductance (nS/pF) sensitive to the $\mathrm{K}_{\mathrm{ATP}}$ channel blocker, glibenclamide $(10 \mu \mathrm{mol} / \mathrm{L})$, in smooth muscle cells from WT $(0.048 \pm 0.01)$ but not $\mathrm{A}_{2 \mathrm{~A}} / \mathrm{A}_{2 \mathrm{~B}} \mathrm{DKO}(0.016 \pm 0.007)$ mice. Also, pinacidil (10 $\mu \mathrm{mol} / \mathrm{L}$; a $\mathrm{K}_{\mathrm{ATP}}$ channel opener) activated the same conductance similarly in cells from both WT and $\mathrm{A}_{2 \mathrm{~A}} / \mathrm{A}_{2 \mathrm{~B}} \mathrm{DKO}$ mice $(0.013 \pm 0.034$ vs. $0.012 \pm 0.04 \mathrm{nS} / \mathrm{pF}$ ) (Figure 4).

Involvement of $\mathrm{H}_{2} \mathrm{O}_{2}$ in adenosine-induced increase in coronary flow. To test if $\mathrm{H}_{2} \mathrm{O}_{2}$ induces coronary vasodilation, we performed exogenous $\mathrm{H}_{2} \mathrm{O}_{2}$ concentration-curve. Exogenous $\mathrm{H}_{2} \mathrm{O}_{2}$ significantly increased the coronary flow from baseline (from 11.3 to $38.1 \mathrm{ml} / \mathrm{min} / \mathrm{g}$, data not shown). We used catalase $(1250 \mathrm{u} / \mathrm{ml})$, an enzyme which breaks down hydrogen peroxide into water and oxygen, to test its effect on adenosine-induced increase in CF in WT mice. Catalase significantly decreased adenosine-induced increase in CF in WT (from $30 \pm 4.4$ to $8.4 \pm 1$ $\mathrm{ml} / \mathrm{min} . \mathrm{g}, \mathrm{n}=4$ ), $\mathrm{A}_{2 \mathrm{~A}} \mathrm{KO}$ (from $33.2 \pm 2.3$ to $9.9 \pm 1 \mathrm{ml} / \mathrm{min} / \mathrm{g}, \mathrm{n}=4$ ), and $\mathrm{A}_{2 \mathrm{~B}} \mathrm{KO}$ (from $35.2 \pm 1.5$ to $13.4 \pm 0.8 \mathrm{ml} / \mathrm{min} / \mathrm{g}, \mathrm{n}=4$ ) mice (Figure $5 \mathrm{~A}$ ). Catalase also significantly decreased adenosineinduced changes in LVDP in WT (from $122.4 \pm 11$ to $78 \pm 7 \mathrm{mmHg}$ ), $\mathrm{A}_{2 \mathrm{~A}} \mathrm{KO}$ (from $119.2 \pm 4.1$ 
to $74.6 \pm 4 \mathrm{mmHg}$ ), and $\mathrm{A}_{2 \mathrm{~B}} \mathrm{KO}$ (from $139.1 \pm 6$ to $81 \pm 10.1 \mathrm{mmHg}$ ) mice while it had no effect on HR (Figures 5 B-C).

Involvement of $\mathrm{H}_{2} \mathrm{O}_{2}$ in coronary reactive hyperemia. Since we showed that adenosine is involved in coronary $\mathrm{RH}$ and that it induces coronary vasodilation through release of $\mathrm{H}_{2} \mathrm{O}_{2}$, we wanted to test if $\mathrm{H}_{2} \mathrm{O}_{2}$ itself is also involved in coronary $\mathrm{RH}$. Therefore, we used catalase (1250 $\mathrm{u} / \mathrm{ml}$ ) in WT mice. Catalase significantly decreased the flow debt-to-repayment ratio in WT compared with its control, $0.8 \pm 0.1(\mathrm{n}=6)$ vs. $1.3 \pm 0.1(\mathrm{n}=6)$, respectively (Figure 6B). However, the resting flow was similar to WT in the presence of catalase $(21.4 \pm 2.1 \mathrm{ml} / \mathrm{min} / \mathrm{g}, \mathrm{n}=6)$ compared to its control $(19.8 \pm 0.9 \mathrm{ml} / \mathrm{min} / \mathrm{g}, \mathrm{n}=6)$ (Table 1$)$. Nevertheless, the peak flow in WT mice, in the presence of catalase, $(38.6 \pm 2.4 \mathrm{ml} / \mathrm{min} / \mathrm{g}, \mathrm{n}=6)$ was also significantly attenuated compared to its control $(42.7 \pm 2 \mathrm{ml} / \mathrm{min} / \mathrm{g}, \mathrm{n}=6$ ) (Figure 6C).

Involvement of $\mathrm{H}_{2} \mathrm{O}_{2}$ in $\mathrm{A}_{2} \mathrm{AR}$-mediatesd coronary reactive hyperemia. We used catalase $(1250 \mathrm{u} / \mathrm{ml})$ in $\mathrm{A}_{2 \mathrm{~A}} \mathrm{KO}$ mice in order to investigate the role of $\mathrm{H}_{2} \mathrm{O}_{2}$ in $\mathrm{A}_{2 \mathrm{~A}} \mathrm{AR}$-induced effects in coronary RH. Catalase significantly decreased the flow debt-to-repayment ratio in $\mathrm{A}_{2 \mathrm{~A}} \mathrm{KO}$ $(0.9 \pm 0.1, n=6)$ (Figure 7B) compared with WT in the absence of catalase $(1.3 \pm 0.1, n=5)$ (Figures $1,2,3$, and 6 B) while, it was not different compared to WT $(0.8 \pm 0.1, n=6)$ in the presence of catalase. Also, there was no difference between flow debt-to-repayment ratio in $\mathrm{A}_{2 \mathrm{~A}} \mathrm{KO}$ in presence of catalase $(0.9 \pm 0.1, \mathrm{n}=6)$ compared with $\mathrm{A}_{2 \mathrm{~A}} \mathrm{KO}(0.9 \pm 0.1, \mathrm{n}=8)$ (Figures $\left.7 \mathrm{~B}\right)$. Further resting flow of $\mathrm{A}_{2 \mathrm{~A}} \mathrm{KO}$ in the presence of catalase $(16.8 \pm 0.9 \mathrm{ml} / \mathrm{min} / \mathrm{g})$ was significantly lower compared with WT $(19.8 \pm 0.9 \mathrm{ml} / \mathrm{min} / \mathrm{g})$ and $\mathrm{A}_{2 \mathrm{~A}} \mathrm{KO}(19.4 \pm 1.6 \mathrm{ml} / \mathrm{min} / \mathrm{g})$ in the absence of catalase, while there was no difference between the two latter groups (Table 1). The peak flow in $\mathrm{A}_{2 \mathrm{~A}} \mathrm{KO}$, in the presence of catalase, $(36.3 \pm 1.4 \mathrm{ml} / \mathrm{min} / \mathrm{g}, \mathrm{n}=6)$ (Figure $7 \mathrm{C}$ ) was significantly lower compared with WT $(42.7 \pm 2 \mathrm{ml} / \mathrm{min} / \mathrm{g}, \mathrm{n}=6)$ (Figure $1 \mathrm{C})$ and $\mathrm{A}_{2 \mathrm{~A}} \mathrm{KO}(42.9 \pm 1.7 \mathrm{ml} / \mathrm{min} / \mathrm{g}, \mathrm{n}=8)$ in the absence of catalase (Figure 7C); this is when the WT and $\mathrm{A}_{2 \mathrm{~A}} \mathrm{KO}$ peak flow, in the presence of catalase, were similar (Figure 1C). These findings may suggest that $\mathrm{A}_{2 \mathrm{~A}} \mathrm{ARs}$ may, at least in part, play their role in coronary $\mathrm{RH}$ through release of $\mathrm{H}_{2} \mathrm{O}_{2}$. 
$\mathrm{H}_{2} \mathrm{O}_{2}$ activates $K_{A T P}$ channels. In smooth muscle cells from WT mice, $\mathrm{H}_{2} \mathrm{O}_{2}(1 \mathrm{mmol} / \mathrm{L})$ activated a glibenclamide-sensitive conductance $(0.074 \pm 0.02 \mathrm{nS} / \mathrm{pF})$ (Figure 8). 
Fig. 4.1 Repayment volume (B), but not resting flow (A) or peak flow (C), is reduced in $A_{2 A} K O(n=8)$ mice, compared with WT $(n=6)$, in coronary RH. *Significant difference compared with WT, $p<0.05$.
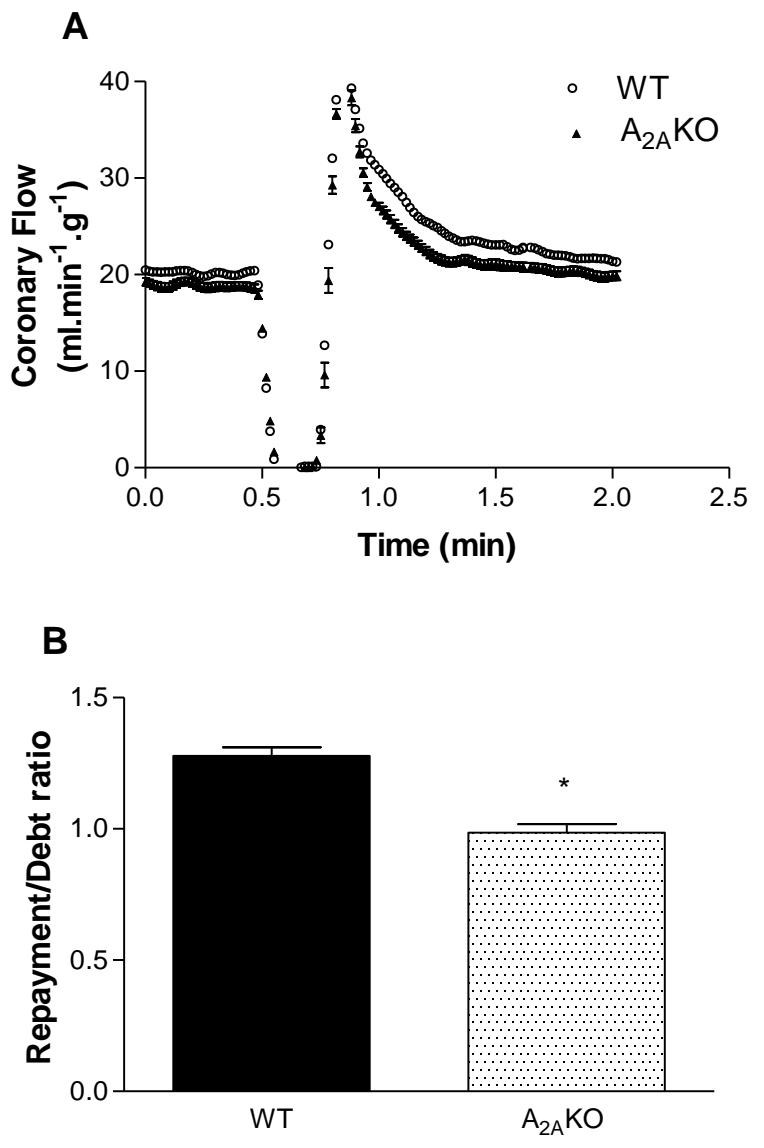

C

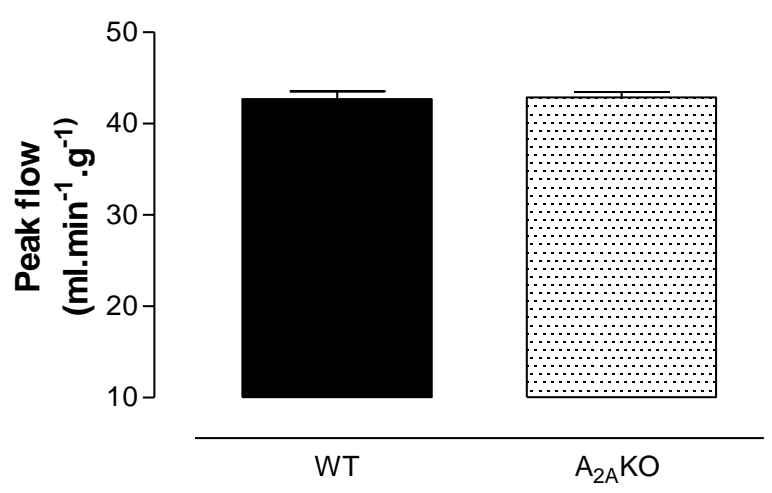


Fig. 4.2 Baseline coronary flow (A), peak flow (B), and flow repayment area (C) of coronary $R H$ are normal in $A_{2 B} K O(n=4)$ mice compared with WT $(n=6)$.
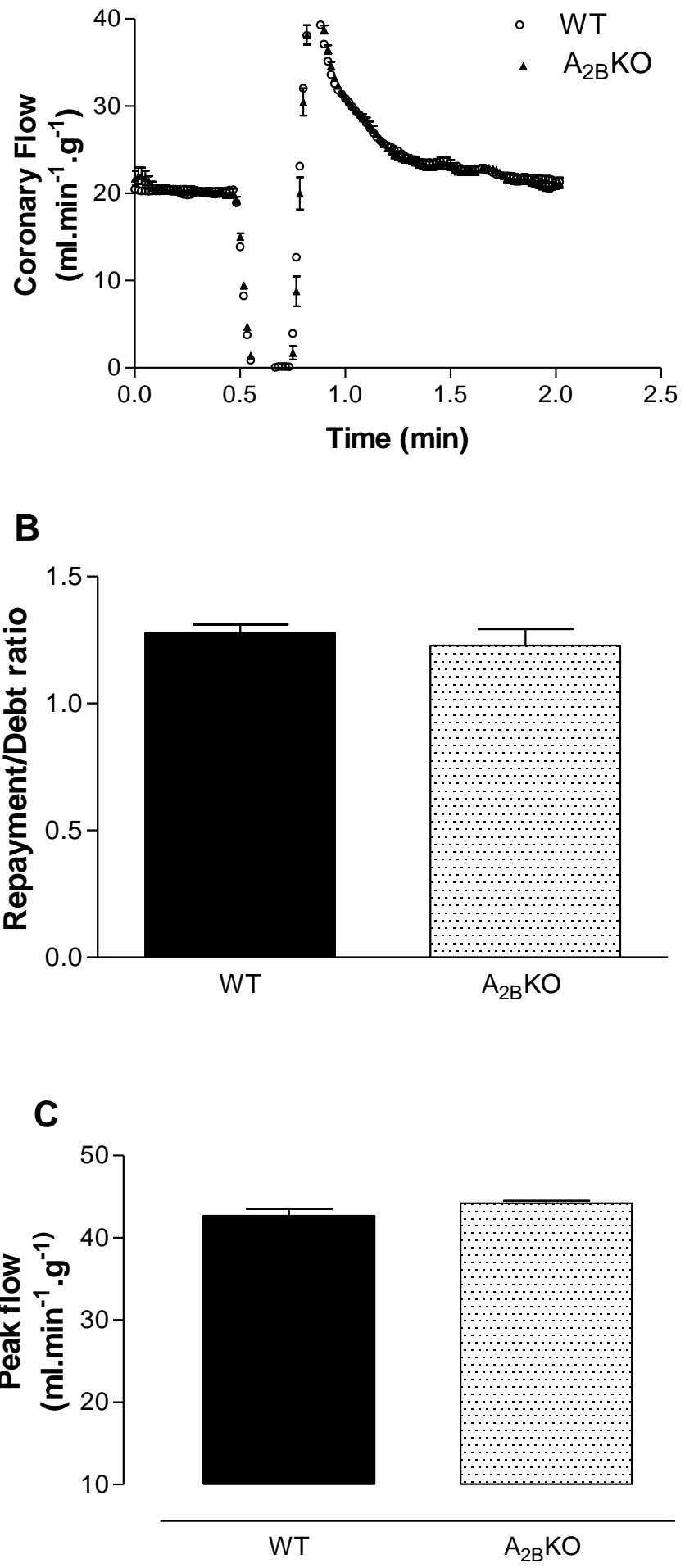
Fig. 4.3 Changes on coronary flow (A), peak flow (B), and flow repayment area (C) in WT $(n=6)$ and $A_{2 A / 2 B} D K O(n=8)$ mice during coronary RH. *Significant difference compared with WT, $p<0.05$.
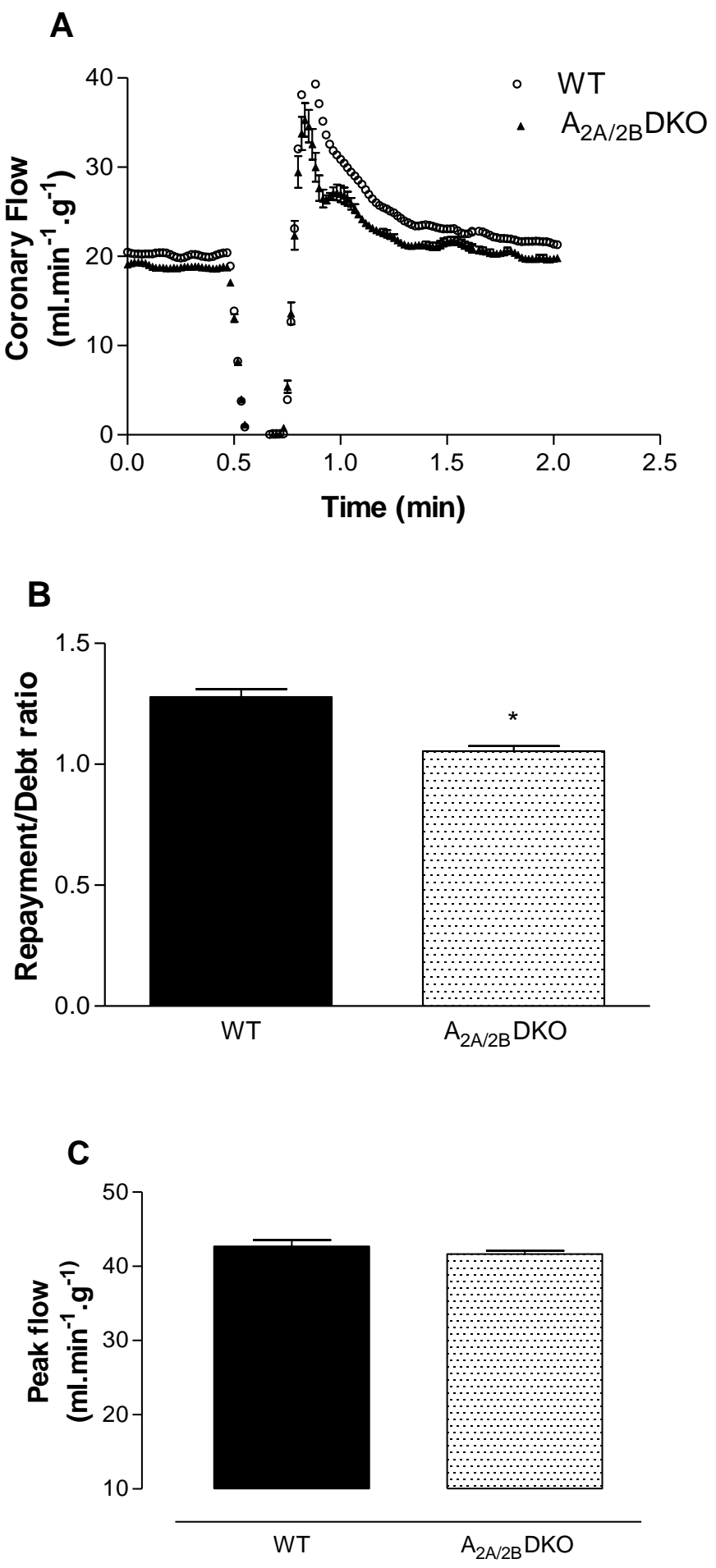
Fig. 4.4 Adenosine-induced KATP current is reduced in smooth muscle cells of $A_{2 \mathrm{~A} / 2 \mathrm{~B}} \mathrm{DKO}$ mice. (A) Glibenclamide-sensitive conductance ( $\mathrm{nS} / \mathrm{pF}$ ) in $\mathrm{WT}$ and $\mathrm{A}_{2 \mathrm{~A} / 2 \mathrm{~B}} \mathrm{DKO}$ mice. (B) Group data showing reduced effect of adenosine in $A_{2 \mathrm{~A} / 2 \mathrm{~B}} \mathrm{DKO}$ mice $(\mathrm{n}=4)$, but response to pinacidil were not different from WT $(n=5)$. *Significant difference compared with WT, $p<0.05$.

A

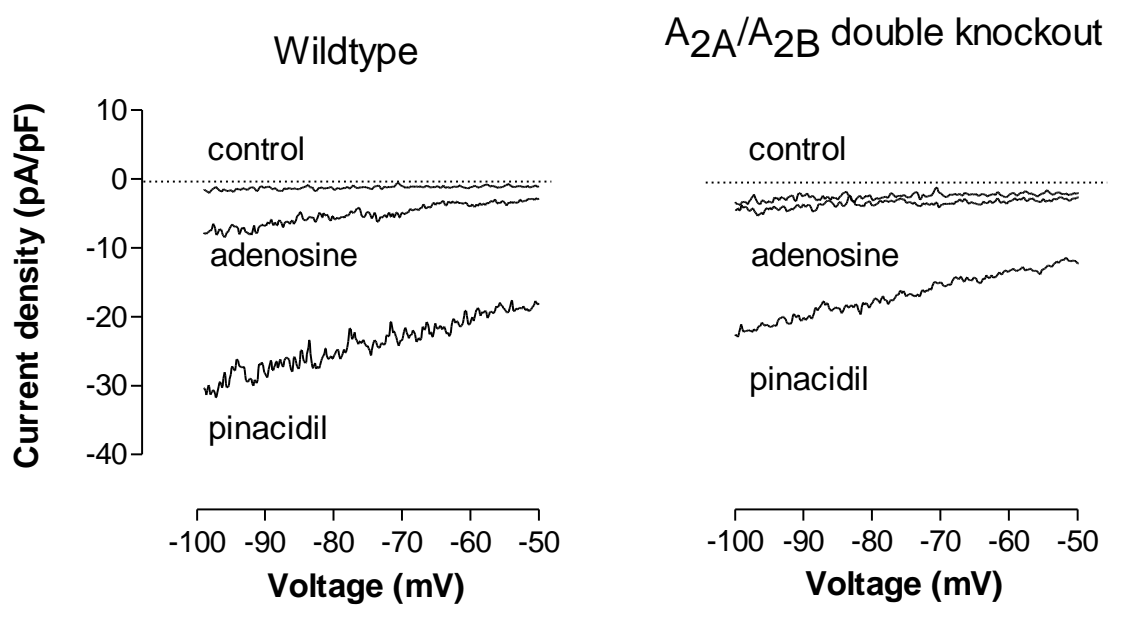

B

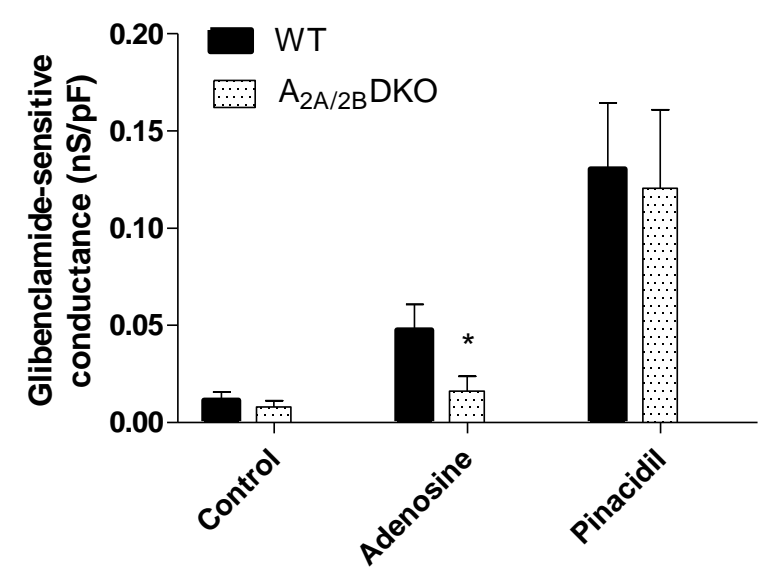


Fig. 4.5 Attenuated adenosine-induced increase in coronary flow (A) and LVDP (C), and normal heart rate $(B)$, in WT $(n=4), A_{2 A} K O(n=4)$, and $A_{2 B} K O(n=4)$ mice, in the presence of catalase (Cat). *Significant difference compared to corresponding control, $p<0.05$.
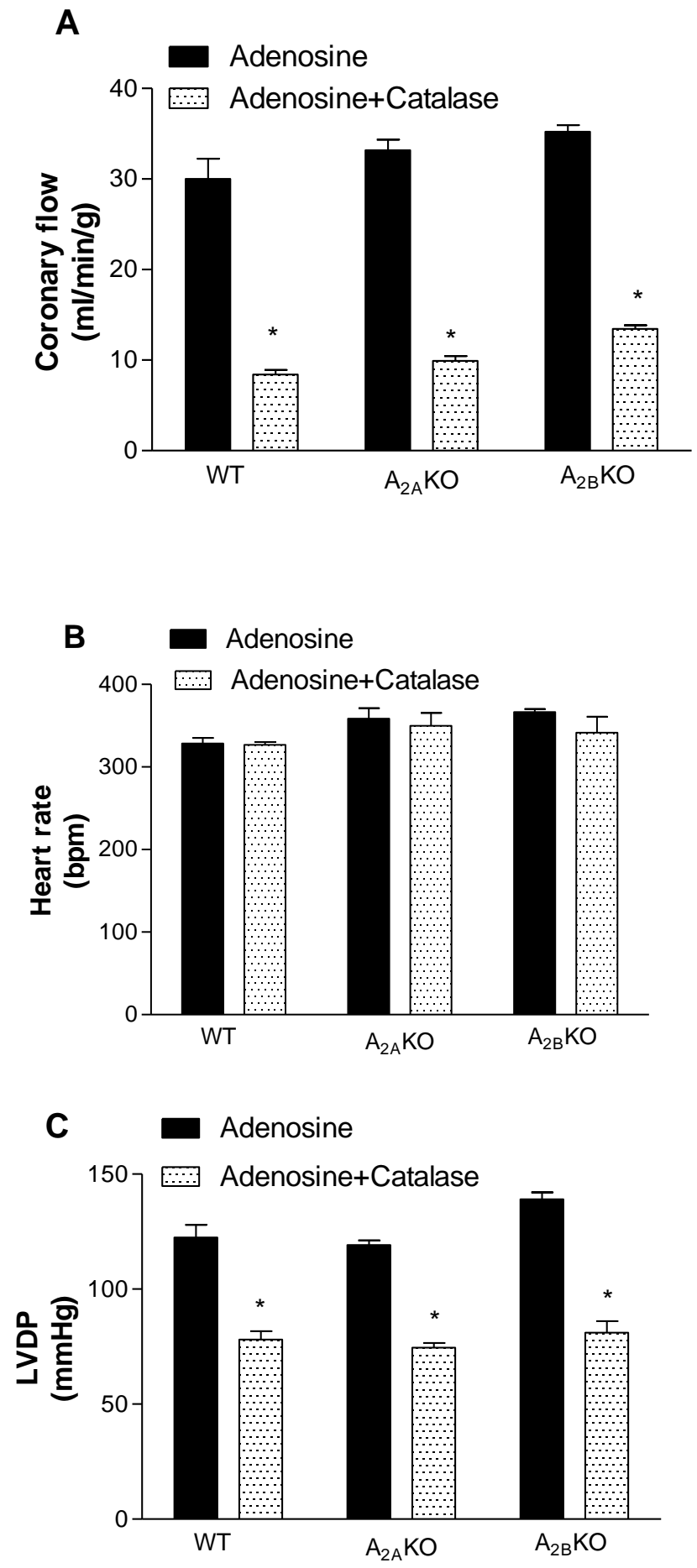
Fig. 4.6 Attenuated peak flow (B) and Repayment area (C), but normal baseline CF (A), in the presence of catalase (Cat) in WT ( $=6$ ) mice. *Significant difference compared with WT, $p<0.05$.

A

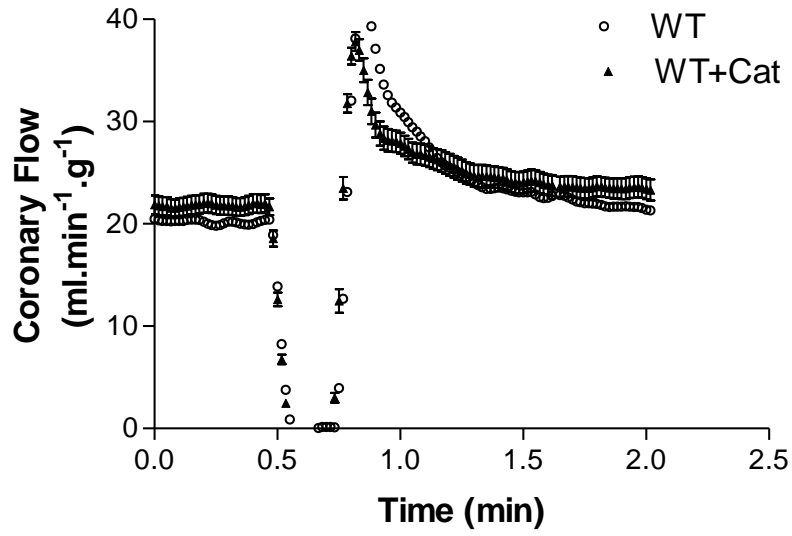

B

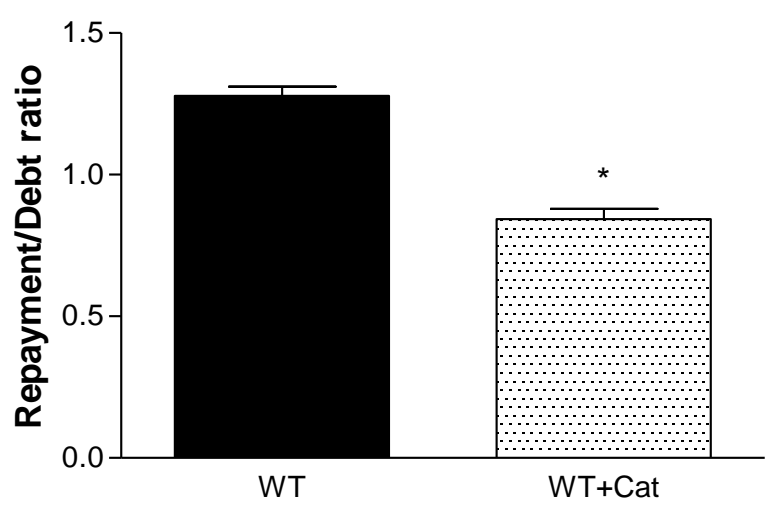

C

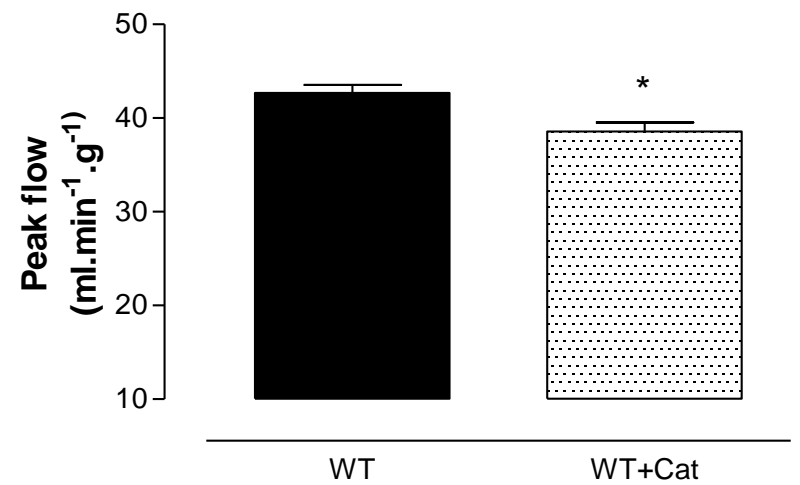


Fig. 4.7 Reactive hyperemia-induced changes on coronary flow (A), peak flow (B), and flow repayment area $(C)$ in the presence $(n=6)$ and absence $(n=8)$ of catalase $($ Cat $)$ in $A_{2 A} K O$ mice.
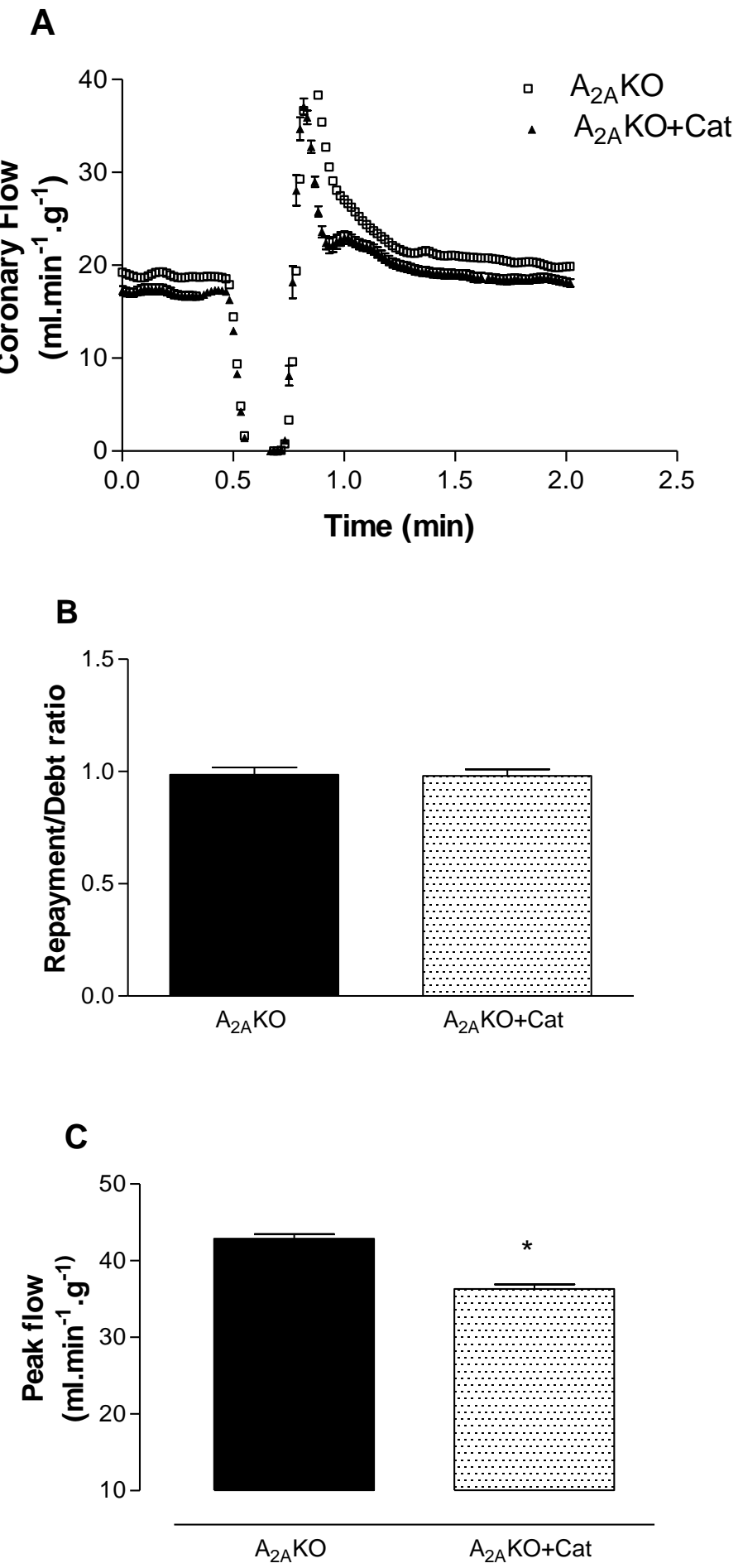
Fig. 4.8 $\mathrm{H}_{2} \mathrm{O}_{2}$ increases a glibenclamide-sensitive conductance (nS/pF) in WT smooth muscle cells. (A) Representative trace showing effect of $\mathrm{H}_{2} \mathrm{O}_{2}$ to increase $\mathrm{K}_{\mathrm{ATP}}$ current. (B) Group data ( $\mathrm{n}=5$ mice) illustrate effect of $\mathrm{H}_{2} \mathrm{O}_{2}$ relative to pinacidil. *Significant difference compared with control, $p<0.05$.
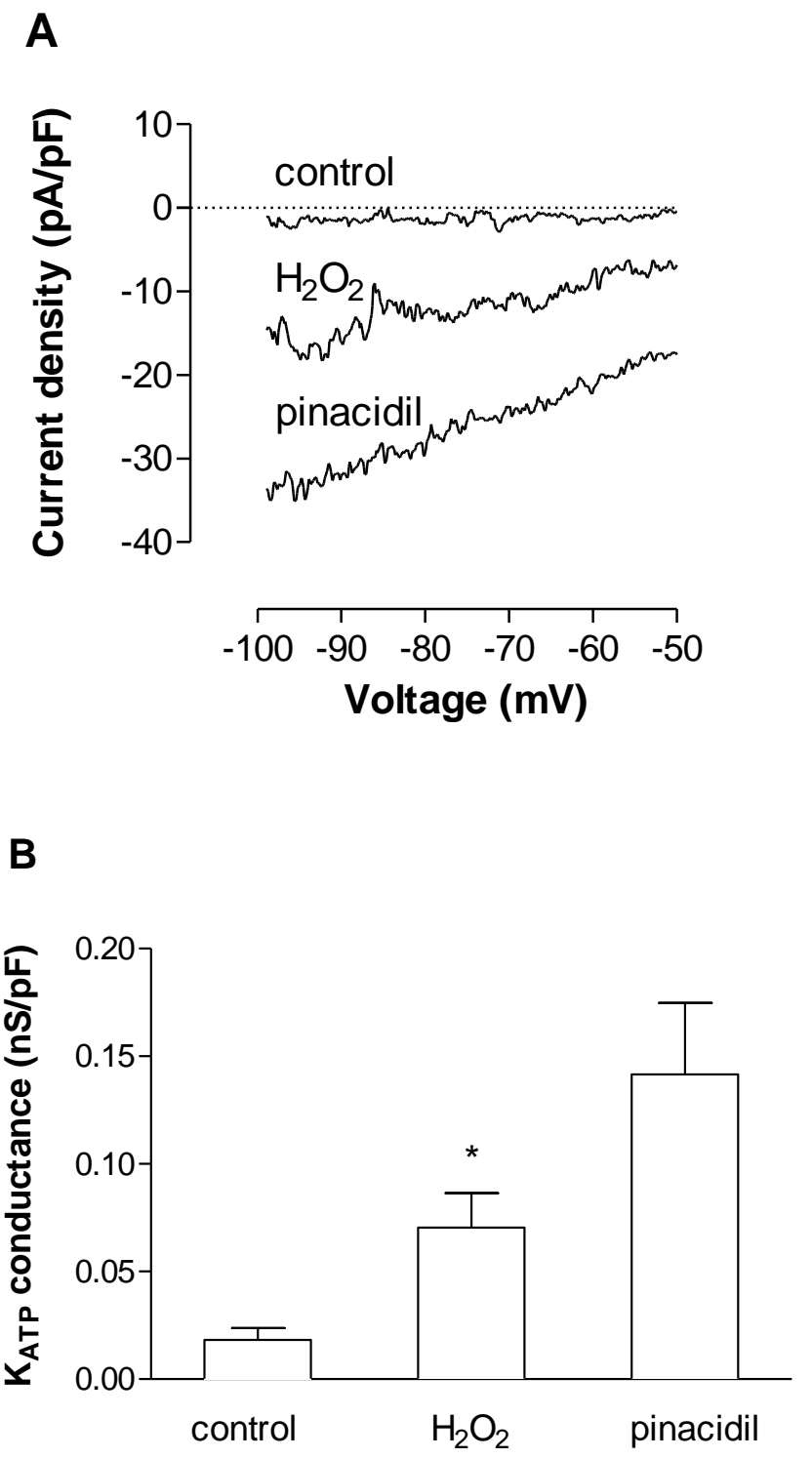
Fig. 4.9 Effect of catalase on adenosine and pinacidil mediated increase in glibenclamide-sensitive conductance $(\mathrm{nS} / \mathrm{pF})$ in WT smooth muscle cells $(\mathrm{n}=5)$.
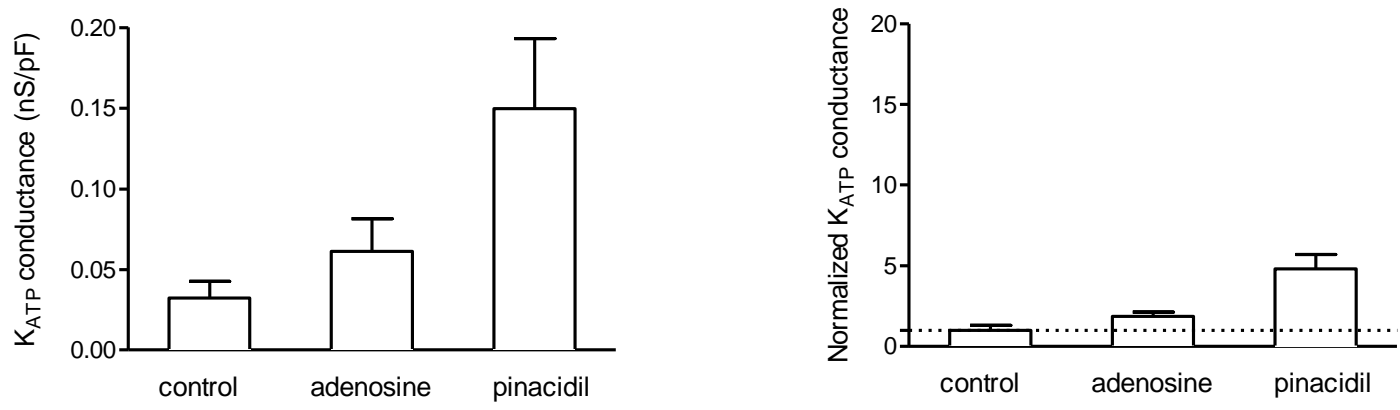


\section{Table 4.1}

Resting flow, debt area (DA), peak flow, flow repayment area (RPA), and debt to repayment area ratio $(\mathrm{RPA} / \mathrm{DA})$.

\begin{tabular}{|c|c|c|c|c|c|}
\hline & $\begin{array}{l}\text { Resting } \\
\text { Flow } \\
(\mathrm{ml} / \mathrm{min} / \mathrm{g})\end{array}$ & $\begin{array}{l}\text { Debt Area } \\
(\mathrm{DA})(\mathrm{ml} / \mathrm{g})\end{array}$ & $\begin{array}{l}\text { Peak } \\
(\mathrm{ml} / \mathrm{min} / \mathrm{g})\end{array}$ & $\begin{array}{l}\text { Repayment } \\
\text { Area } \\
(\mathrm{RPA}) \\
(\mathrm{ml} / \mathrm{g})\end{array}$ & $\begin{array}{l}\text { Debt to } \\
\text { Repayment } \\
\text { area } \\
\text { RPA/DA }\end{array}$ \\
\hline WT & $19.8 \pm 0.9$ & $4.9 \pm 0.2$ & $42.7 \pm 2$ & $6.3 \pm 0.4$ & $1.3 \pm 0.1$ \\
\hline $\mathrm{A}_{2 \mathrm{~A}} \mathrm{KO}$ & $19.4 \pm 1.6$ & $4.9 \pm 0.4$ & $42.9 \pm 1.7$ & $4.5 \pm 0.2 *$ & $0.9 \pm 0.1 *$ \\
\hline $\mathrm{A}_{2 \mathrm{~B}} \mathrm{KO}$ & $20.3 \pm 1.1$ & $5.1 \pm 0.3$ & $44.2 \pm 0.5$ & $6.1 \pm 0.1$ & $1.2 \pm 0.1$ \\
\hline $\mathrm{A}_{2 \mathrm{~A} / 2 \mathrm{~B}} \mathrm{KO}$ & $18.6 \pm 0.6$ & $4.7 \pm 0.1$ & $41.6 \pm 1.2$ & $4.9 \pm 0.2 *$ & $1 \pm 0.1^{*}$ \\
\hline WT+Cat & $21.4 \pm 2.1$ & $5.3 \pm 0.5$ & $38.6 \pm 2.4^{*}$ & $4.4 \pm 0.4^{*}$ & $0.8 \pm 0.1 *$ \\
\hline $\mathrm{A}_{2 \mathrm{~A}} \mathrm{KO}+\mathrm{Cat}$ & $16.8 \pm 0.9^{*}$ & $4.2 \pm 0.2 *$ & $36.3 \pm 1.4^{*}$ & $4.1 \pm 0.4^{*}$ & $0.9 \pm 0.1 *$ \\
\hline All values ar & $\mathrm{s} \pm$ S.E.M. & $<0.05$ compa & d with WT & & \\
\hline
\end{tabular}




\section{Discussion}

The new findings in this study show: 1) a better elucidation of the individual involvement of $\mathrm{A}_{2 \mathrm{~A}} \mathrm{ARs}$ in $\mathrm{RH}, 2$ ) a demonstration that $\mathrm{H}_{2} \mathrm{O}_{2}$ contributes to $\mathrm{CF}$ responses in $\mathrm{RH}$, and 3) that $\mathrm{H}_{2} \mathrm{O}_{2}$ couples adenosine-mediated $\mathrm{CF}$ responses in $\mathrm{RH}$ to $\mathrm{K}_{\mathrm{ATP}}$ channel activation. Using $\mathrm{A}_{2 \mathrm{~A}}$ and $\mathrm{A}_{2 \mathrm{~B}} \mathrm{KO}$ and $\mathrm{A}_{2 \mathrm{~A} / 2 \mathrm{~B}} \mathrm{DKO}$ mice, we showed that only $\mathrm{A}_{2 \mathrm{~A}} \mathrm{AR}$, out of four $\mathrm{AR}$ subtypes, is involved in RH. Additionally, we showed for the first time the involvement of $\mathrm{H}_{2} \mathrm{O}_{2}$ in mouse coronary $\mathrm{RH}$ in addition to its involvement in $\mathrm{A}_{2 \mathrm{~A}} \mathrm{AR}$-induced $\mathrm{K}_{\mathrm{ATP}}$ channel activation.

Increased oxygen demand over oxygen supply ratio of the myocardium is exerted through myocardial oxygen tension $\left(\mathrm{pO}_{2}\right)$, which is decreased in ischemic conditions. This fall in $\mathrm{pO}_{2}$ leads to the breakdown of adenine nucleotides leading to the production of adenosine that is known to mediate local metabolic control of CF (14). Previous RH studies investigating the effect of different occlusion periods suggested that metabolic vasodilatory factors are the primary mediators responsible for the increase in flow during $\mathrm{RH}(7,17,38,39)$. Further, our laboratory and others have previously shown that activation of $\mathrm{A}_{2 \mathrm{~A}}$ and $\mathrm{A}_{2 \mathrm{~B}} \mathrm{ARs}$ induces an increase in $\mathrm{CF}$ $(37,46,49)$. Therefore, in this study, we wanted to test the role of adenosine, a well established local metabolite, in $\mathrm{CF}$ changes in $\mathrm{RH}$. The involvement of adenosine in coronary $\mathrm{RH}$ was recently reported in an in vivo dog study, where the AR subtypes involved was not assessed (11). Nevertheless, using an $\mathrm{A}_{2 \mathrm{~A}} \mathrm{AR}$ selective antagonist (SCH58261), Zatta et al. reported coronary $\mathrm{RH}$ responses mediated by $\mathrm{A}_{2 \mathrm{~A}} \mathrm{ARs}$ with a flow repayment area decrease of up to $30 \%$ and no change in peak flow (62). Also, in a previous in vivo study in dogs, the role of $\mathrm{A}_{2 \mathrm{~B}} \mathrm{AR}$-mediated $\mathrm{CF}$ changes in RH was assessed using a non-selective antagonist (alloxazine) which is only about 10 fold more selective towards $A_{2 B} A R s$ relative to $A_{2 A} A R s$ (2). Therefore, a further study was needed in order to fully elucidate the role of ARs in coronary RH without the effect of pharmacological changes. The availability of gene deleted knockout mice has been an important tool to analyze the physiological and pharmacological pathways for elucidating the role of a single receptor. Therefore, in this study, using $\mathrm{A}_{2 \mathrm{~A}}$ and $\mathrm{A}_{2 \mathrm{~B}} \mathrm{KO}$ isolated mice hearts, we directly 
showed that $\mathrm{A}_{2 \mathrm{~A}} \mathrm{ARs}$ contribute to $\mathrm{CF}$ changes in mouse coronary $\mathrm{RH}$ by demonstrating a significant decrease in flow repayment time and volume (flow repayment area) in $\mathrm{A}_{2 \mathrm{~A}} \mathrm{KO}$ mice compared with WT. These results are in accordance with recent studies showing a role for ARs in flow repayment area and not the peak flow (62). However, our results from $\mathrm{A}_{2 \mathrm{~B}} \mathrm{KO}$ and $\mathrm{A}_{2 \mathrm{~A} / 2 \mathrm{~B}} \mathrm{DKO}$ mice did not suggest any role for $\mathrm{A}_{2 \mathrm{~B}} \mathrm{ARs}$ in $\mathrm{CF}$ changes in $\mathrm{RH}$. Due to its low affinity for adenosine, $\mathrm{A}_{2 \mathrm{~B}} \mathrm{ARs}$ are suggested to be activated in conditions where a significant increase in adenosine levels is observed (15). For example it was reported that $\mathrm{A}_{2 \mathrm{~B}} \mathrm{ARs}$ play a role in ischemia/reperfusion and preconditioning (13). Therefore, $\mathrm{A}_{2 \mathrm{~B}} \mathrm{ARs}$ may be more involved in severe ischemic pathophysiological conditions such as stroke or in protective preconditioning pathways rather than in physiological situations. Indeed, $\mathrm{A}_{2} \mathrm{ARs}$ agonists are being investigated as a treatment during percutaneous coronary intervention for the reduction of myocardial reperfusion injury in patients with myocardial infarction, which is well established to be associated with worsening of cardiac injury and function $(6,10)$.

Berne's adenosine hypothesis suggests that increase in myocardial oxygen consumption decreases the myocardial oxygen tension which leads to the release of adenosine from cardiomyocyte (53), where $\mathrm{A}_{2 \mathrm{~A}} \mathrm{ARs}$ have also been found to be expressed in both human and mouse $(4,24)$. Furthermore, a role for $\mathrm{H}_{2} \mathrm{O}_{2}$ in metabolic vasodilation is already established (59). Chilian et al. suggested that $\mathrm{H}_{2} \mathrm{O}_{2}$ production increases in proportion to cardiac metabolism in order to couple the coronary blood flow to myocardial oxygen tension (45). It is interesting to know that both $\mathrm{H}_{2} \mathrm{O}_{2}$ and adenosine are released from cardiomyocytes through which they modulate vascular tone (19). Nevertheless, it is also well recognized that hemodynamic changesinduced release of mediators are also involved in RH; a sudden increase in flow after reperfusion activates shear stress-sensitive mechanisms $(21,41,52,61)$, illustrating the release of endothelium-dependent derived factors that may limit myogenic constriction and, therefore, modifying the RH time or flow repayment area. In fact, recent reports have established the contribution of $\mathrm{H}_{2} \mathrm{O}_{2}$ in flow-induced dilation of isolated human coronary arteries (29) and in 
reactive dilation of rat isolated coronary arterioles (20). Therefore, in this study, as EDHF in humans and mice $(26,27,58)$, we also investigated the role of $\mathrm{H}_{2} \mathrm{O}_{2}$ in $\mathrm{CF}$ changes during coronary RH using isolated heart (compared with isolated vessels). Additionally, due to the involvement of both adenosine and $\mathrm{H}_{2} \mathrm{O}_{2}$ as metabolic factors regulating $\mathrm{CF}$, in this study, we also tested the involvement of $\mathrm{H}_{2} \mathrm{O}_{2}$ in AR-induced effect in $\mathrm{CF}$ regulation and $\mathrm{RH}$. We showed for the first time that in the presence of catalase, which breaks down $\mathrm{H}_{2} \mathrm{O}_{2}$ into water and oxygen, adenosine-induced increase in $\mathrm{CF}$ is abolished in $\mathrm{WT}, \mathrm{A}_{2 \mathrm{~A}} \mathrm{KO}$ (where $\mathrm{A}_{2 \mathrm{~B}} \mathrm{AR}$ is the only $\mathrm{AR}$ mediating vasodilation), and $\mathrm{A}_{2 \mathrm{~B}} \mathrm{KO}$ (where $\mathrm{A}_{2 \mathrm{~A}} \mathrm{AR}$ is the only $\mathrm{AR}$ mediating vasodilation) (Figure 5), showing that $\mathrm{H}_{2} \mathrm{O}_{2}$ plays a role in $\mathrm{A}_{2} \mathrm{AR}$-mediated signaling pathway when inducing an increase in CF. In this study, we also showed for the first time that the RH repayment time and volume (flow repayment area) in addition to flow debt-to-repayment ratio were significantly decreased in WT isolated mice hearts in the presence of catalase, showing the contribution and release of $\mathrm{H}_{2} \mathrm{O}_{2}$ during coronary $\mathrm{RH}$. Furthermore, since catalase decreased the flow debt-torepayment ratio in both $\mathrm{A}_{2 \mathrm{~A}} \mathrm{KO}$ and WT mice with no difference compared to each other and compared to $\mathrm{A}_{2 \mathrm{~A}} \mathrm{KO}$ in the absence of catalase, we suggest that $\mathrm{H}_{2} \mathrm{O}_{2}$ released during coronary $\mathrm{RH}$ is, at least partly, mediated through activation of $\mathrm{A}_{2 \mathrm{~A}} \mathrm{ARs}$. Showing that catalase significantly decreased peak flow in WT and $\mathrm{A}_{2 \mathrm{~A}} \mathrm{KO}$ mice (while peak flow of $\mathrm{A}_{2 \mathrm{~A}} \mathrm{KO}$ was not different compared with WT mice in the absence of catalase), may further signify that $\mathrm{H}_{2} \mathrm{O}_{2}$ may also be released through activation of other pathways. Nevertheless, using patch clamp studies, we showed that $\mathrm{H}_{2} \mathrm{O}_{2}$ increases glibenclamide ( $\mathrm{K}_{\text {АTP }}$ channels blocker) sensitive currents. Putting together these findings with our previous and current results, showing that adenosine activates $\mathrm{K}_{\text {ATP }}$ channels by means of its $\mathrm{A}_{2} \mathrm{ARs}$, we are suggesting that, at least partly, $\mathrm{H}_{2} \mathrm{O}_{2}$ couples the activation of $\mathrm{ARs}$ to $\mathrm{K}_{\mathrm{ATP}}$ channels during coronary $\mathrm{RH}$. Nevertheless, further in vivo and in vitro studies are needed to fully elucidate the complex mechanisms of action involved in RH. We also have to highlight that the magnitude of hyperemia is also determined by the baseline flow. In this study, we observed that $\mathrm{H}_{2} \mathrm{O}_{2}$ or knocking out of the $\mathrm{A}_{2 \mathrm{~A}} \mathrm{ARs}$, solely, do not decrease the baseline 
CF; however, synergistically they significantly decrease the CF baseline, which by itself may suggest that there might be a compensatory relationship between $\mathrm{A}_{2 \mathrm{~A}} \mathrm{ARs}$ and $\mathrm{H}_{2} \mathrm{O}_{2}$ (Table 1).

Since, in this study, we used isolated heart, the contribution of flow/shear stress- or pressure-dependent coronary mechanisms in the development of $\mathrm{RH}$ could not be clearly elucidated or isolated from the effect of local metabolic factors. However, an ex vivo isolated heart model certainly provides us with more valuable data closer to the physiological in vivo responses compared with in vitro isolated vessels, since it reflects the overall end effect of shear/pressure stress- and metabolites-induced effects during coronary RH. Additionally, an ex vivo study, such as the current study, eliminates the complexity of the role of neuronal and hormonal effects and, hence, enabling us to better understand the tissue selective responses and mechanisms involved during coronary RH. We also have to mention a second limitation of our study that has to do with performing patch clamp experiments on smooth muscle cells from aorta, as a model to complement functional studies from the coronary arteries. Perhaps a better approach would be to study smooth muscle cells isolated from mouse coronary arteries or arterioles. However, to our knowledge, there are no reports using mouse coronary smooth muscle in patch clamp setting in order to study ion channel currents due to its own limitations such as isolation and experimental procedures required. Therefore, most studies investigating coronary ion channels show currents from aorta as a tool $(5,23,28)$. Also, $\mathrm{K}_{\text {ATP }}$ channels are known to be important regulators of coronary vascular tone in mice $(5,28)$. Thus, aortic smooth muscle cells appear to be an appropriate substitute for coronary smooth muscle cells in this regard.

The release of $\mathrm{H}_{2} \mathrm{O}_{2}$, as endothelium-derived hyperpolarizing factor (EDHF) in mice and humans $(26,27)$, could be induced by various factors. Morikawa et al. suggested that $\mathrm{Cu}, \mathrm{Zn}-\mathrm{SOD}$ plays an important role as an EDHF synthase in mice (31). It is also likely that $\mathrm{H}_{2} \mathrm{O}_{2}$ is produced from superoxide anions from several sources in endothelium, such as eNOS, lipoxygenase, cytochrome $p-450$ enzymes, and NADPH oxidases (27). Further, it is reported that adenosinemediated effects are partially endothelium dependent and that adenosine also induces vasodilation 
through production of cytochrome $p-450$ metabolites $(34,35)$, NO (50), and NADPH oxidases (data not shown). Therefore, comparing these signaling pathways, one may speculate that adenosine-induced release of $\mathrm{H}_{2} \mathrm{O}_{2}$ may involve activation of epoxygenases pathway, eNOS, or NADPH oxidase. However, further studies are needed to identify these signaling pathways.

It is known that $\mathrm{H}_{2} \mathrm{O}_{2}$ induces vasodilation; however, there are also reports showing that $\mathrm{H}_{2} \mathrm{O}_{2}$ induces vasoconstriction $(8,16,30)$ and that $\mathrm{H}_{2} \mathrm{O}_{2}$ inhibits vasodilation to adenosine in isolated porcine coronary arteries (51). Nonetheless, it was suggested that the vascular effect of $\mathrm{H}_{2} \mathrm{O}_{2}$ depends on its concentration (8). To the best of our knowledge there is limited information on the endogenous level of $\mathrm{H}_{2} \mathrm{O}_{2}$, however, $\mathrm{H}_{2} \mathrm{O}_{2}$ levels between 2.5-50 $\mu$ mol/L have been reported in human plasma $(9,22,54)$. Exogenous infusion of $\mathrm{H}_{2} \mathrm{O}_{2}$, up to $6 \times 10^{-6} \mathrm{~mol} / \mathrm{L}(6 \mu \mathrm{mol} / \mathrm{L})$, caused a significant increase in $\mathrm{CF}$ in isolated mouse heart (data not shown) from which point onward (at $10^{-5} \mathrm{~mol} / \mathrm{L}$ ) $\mathrm{H}_{2} \mathrm{O}_{2}$ started to induce coronary vasoconstriction which was also accompanied by a decrease in left ventricle pressure and $+d p / d t$ (data not shown). It seems that endothelial cells are less vulnerable to $\mathrm{H}_{2} \mathrm{O}_{2}$ since a relatively high concentration of $\mathrm{H}_{2} \mathrm{O}_{2}>200$ $\mu \mathrm{mol} / \mathrm{L}$ is generally required to produce irreversible endothelial barrier dysfunction $(40,56)$. Therefore, $\mathrm{H}_{2} \mathrm{O}_{2}$-induced decrease in $\mathrm{CF}$ at $10^{-5} \mathrm{~mol} / \mathrm{L}$ concentration may be due to $\mathrm{H}_{2} \mathrm{O}_{2}$-induced damaging effect on cardiomyocytes. Nevertheless, our study showed a significant increase in CF between $10^{-6}-6 \times 10^{-6} \mathrm{~mol} / \mathrm{L}$. Therefore, the discrepancy between our study and other studies regarding $\mathrm{H}_{2} \mathrm{O}_{2}$-induced effects may be dependent on the level of $\mathrm{H}_{2} \mathrm{O}_{2}$ released. For example, Thengchaisri et al. showed that $\mathrm{H}_{2} \mathrm{O}_{2}$ in concentrations below $10 \mu \mathrm{mol} / \mathrm{L}$ did not modify NOmediated vasodilatory responses. Such variations may also be dependent on the species, vascular beds, and experimental models such as ex vivo vs. in vitro. However, overall, we can only speculate that $\mathrm{H}_{2} \mathrm{O}_{2}$ concentration released due to coronary RH may be in the range of $10^{-6}-6 \times 10^{-}$ ${ }^{6} \mathrm{~mol} / \mathrm{L}$.

It is well established that activation of $\mathrm{K}_{\mathrm{ATP}}$ channels plays a major role in coronary $\mathrm{RH}$ in addition to its contribution to AR-mediated CF changes $(2,48,62)$. However, identification of 
the factor(s) that activates these channels was not assessed in previous studies. Recent studies have shown the association of $\mathrm{K}^{+}$ions in $\mathrm{H}_{2} \mathrm{O}_{2}$-induced vasodilation $(42,43,45)$. These channels were also shown to mediate, at least in part, $\mathrm{H}_{2} \mathrm{O}_{2}$-induced dilation of arterioles from skeletal muscle and brain $(25,55)$. Further, it has been shown that $\mathrm{H}_{2} \mathrm{O}_{2}$ activates $\mathrm{K}_{\text {ATP }}$ channels in pancreatic beta cells and cardiac myocytes $(18,33)$. Nevertheless, direct evidence of this mechanism in smooth muscle and the role of adenosine as the inducer of this mechanism is lacking. In this study, we showed for the first time that $\mathrm{K}_{\mathrm{ATP}}$ channels on smooth muscle cells are activated by $\mathrm{H}_{2} \mathrm{O}_{2}$ and, at least partly, adenosine induces the release of $\mathrm{H}_{2} \mathrm{O}_{2}$ and, hence, activation of $\mathrm{K}_{\mathrm{ATP}}$ channels. It is worth mentioning that $\mathrm{A}_{2} \mathrm{AR}$-induced increase in $\mathrm{CF}$ is through activation of non-mitochondrial $\mathrm{K}_{\mathrm{ATP}}$ channels (48) and, therefore, one can speculate that at least the source of $\mathrm{H}_{2} \mathrm{O}_{2}$-induced $\mathrm{CF}$ changes in $\mathrm{RH}$ due to activation of ARs may not be mitochondria related. However, further experiments are needed to better understand the role of mitochondrial and non-mitochondrial $\mathrm{K}_{\mathrm{ATP}}$ channels in $\mathrm{RH}$ coronary flow responses.

Finally catalase induced a decrease in adenosine-induced increase in LVDP. This inhibition may be due to Gregg's effect since at this concentration adenosine has significantly increased both CF and LVDP. The opening of $\mathrm{K}_{\mathrm{ATP}}$ channels may also affect the contractility independent of $\mathrm{CF}$ changes. It is worth mentioning that adenosine is shown to activate $\mathrm{K}_{\mathrm{ATP}}$ channels and that glibenclamide, a $\mathrm{K}_{\mathrm{ATP}}$ channel blocker, is reported to decrease reactive oxygen species (36). Nevertheless, further studies are needed to better understand the role of $\mathrm{H}_{2} \mathrm{O}_{2}$ in LVDP.

This study is another step in the direction of better understanding of the CF regulation and its heterogeneity that may help us towards development of treatments for various clinical uses such as evaluation of endothelial integrity and reperfusion of coronary arteries after an embolism. 


\section{References:}

1. Aversano T, Ouyang P, and Silverman H. Blockade of the ATP-sensitive potassium channel modulates reactive hyperemia in the canine coronary circulation. Circ Res 69: 618-622, 1991.

2. Berwick ZC, Payne GA, Lynch B, Dick GM, Sturek M, and Tune JD. Contribution of adenosine $\mathrm{A}(2 \mathrm{~A})$ and $\mathrm{A}(2 \mathrm{~B})$ receptors to ischemic coronary dilation: role of $\mathrm{K}(\mathrm{V})$ and $\mathrm{K}(\mathrm{ATP})$ channels. Microcirculation 17: 600-607.

3. Bloomer RJ, Smith WA, and Fisher-Wellman KH. Oxidative stress in response to forearm ischemia-reperfusion with and without carnitine administration. Int J Vitam Nutr Res 80: 12-23, 2010.

4. Chandrasekera PC, McIntosh VJ, Cao FX, and Lasley RD. Differential effects of adenosine A2a and A2b receptors on cardiac contractility. Am J Physiol Heart Circ Physiol 299: H2082-2089, 2010.

5. Chutkow WA, Pu J, Wheeler MT, Wada T, Makielski JC, Burant CF, and McNally EM. Episodic coronary artery vasospasm and hypertension develop in the absence of Sur2 K(ATP) channels. J Clin Invest 110: 203-208, 2002.

6. Claeys MJ, Bosmans J, De Ceuninck M, Beunis A, Vergauwen W, Vorlat A, and Vrints CJ. Effect of intracoronary adenosine infusion during coronary intervention on myocardial reperfusion injury in patients with acute myocardial infarction. Am J Cardiol 94: 9-13, 2004.

7. Coffman JD and Gregg DE. Reactive hyperemia characteristics of the myocardium. Am J Physiol 199: 1143-1149, 1960. 
8. Cseko C, Bagi Z, and Koller A. Biphasic effect of hydrogen peroxide on skeletal muscle arteriolar tone via activation of endothelial and smooth muscle signaling pathways. J Appl Physiol 97: 1130-1137, 2004.

9. Deskur E, Przywarska I, Dylewicz P, Szczesniak L, Rychlewski T, Wilk M, and Wysocki H. Exercise-induced increase in hydrogen peroxide plasma levels is diminished by endurance training after myocardial infarction. Int J Cardiol 67: 219224, 1998.

10. Desmet W, Bogaert J, Dubois C, Sinnaeve P, Adriaenssens T, Pappas C, Ganame J, Dymarkowski S, Janssens S, Belmans A, and Van de Werf F. High-dose intracoronary adenosine for myocardial salvage in patients with acute ST-segment elevation myocardial infarction. Eur Heart J 32: 867-877, 2011.

11. Dick GM, Bratz IN, Borbouse L, Payne GA, Dincer UD, Knudson JD, Rogers $\mathrm{PA}$, and Tune JD. Voltage-dependent $\mathrm{K}+$ channels regulate the duration of reactive hyperemia in the canine coronary circulation. Am J Physiol Heart Circ Physiol 294: H2371-2381, 2008.

12. Duncker DJ, Van Zon NS, Altman JD, Pavek TJ, and Bache RJ. Role of K+ATP channels in coronary vasodilation during exercise. Circulation 88: 1245$1253,1993$.

13. Eckle T, Kohler D, Lehmann R, El Kasmi K, and Eltzschig HK. Hypoxiainducible factor-1 is central to cardioprotection: a new paradigm for ischemic preconditioning. Circulation 118: 166-175, 2008.

14. Feigl EO. Berne's adenosine hypothesis of coronary blood flow control. Am J Physiol Heart Circ Physiol 287: H1891-1894, 2004. 
15. Fredholm BB. Adenosine, an endogenous distress signal, modulates tissue damage and repair. Cell Death Differ 14: 1315-1323, 2007.

16. Grover AK, Samson SE, Misquitta CM, and Elmoselhi AB. Effects of peroxide on contractility of coronary artery rings of different sizes. Mol Cell Biochem 194: 159-164, 1999.

17. Hintze TH and Vatner SF. Reactive dilation of large coronary arteries in conscious dogs. Circ Res 54: 50-57, 1984.

18. Ichinari K, Kakei M, Matsuoka T, Nakashima H, and Tanaka H. Direct activation of the ATP-sensitive potassium channel by oxygen free radicals in guineapig ventricular cells: its potentiation by MgADP. J Mol Cell Cardiol 28: 1867-1877, 1996.

19. Kaneshiro T, Saitoh S, Machii H, Yamaguchi O, Ishibashi T, Maruyama Y, and Takeishi Y. Metabolic regulation of coronary vascular tone: role of hydrogen peroxide, purinergic components, and angiotensin. Eur J Pharmacol 645: 127-134, 2010.

20. Koller A and Bagi Z. Nitric oxide and $\mathrm{H} 2 \mathrm{O} 2$ contribute to reactive dilation of isolated coronary arterioles. Am J Physiol Heart Circ Physiol 287: H2461-2467, 2004. 21. Kuo L, Davis MJ, and Chilian WM. Endothelium-dependent, flow-induced dilation of isolated coronary arterioles. Am J Physiol 259: H1063-1070, 1990.

22. Lacy F, O'Connor DT, and Schmid-Schonbein GW. Plasma hydrogen peroxide production in hypertensives and normotensive subjects at genetic risk of hypertension. J Hypertens 16: 291-303, 1998. 
23. Lu T, Zhang DM, Wang XL, He T, Wang RX, Chai Q, Katusic ZS, and Lee

HC. Regulation of coronary arterial BK channels by caveolae-mediated angiotensin II signaling in diabetes mellitus. Circ Res 106: 1164-1173, 2010.

24. Marala RB and Mustafa SJ. Immunological characterization of adenosine A2A receptors in human and porcine cardiovascular tissues. J Pharmacol Exp Ther 286: 1051-1057, 1998.

25. Marvar PJ, Hammer LW, and Boegehold MA. Hydrogen peroxidedependent arteriolar dilation in contracting muscle of rats fed normal and high salt diets. Microcirculation 14: 779-791, 2007.

26. Matoba T, Shimokawa H, Kubota H, Morikawa K, Fujiki T, Kunihiro I, Mukai Y, Hirakawa Y, and Takeshita A. Hydrogen peroxide is an endotheliumderived hyperpolarizing factor in human mesenteric arteries. Biochem Biophys Res Commun 290: 909-913, 2002.

27. Matoba T, Shimokawa H, Nakashima M, Hirakawa Y, Mukai Y, Hirano K, Kanaide $\mathrm{H}$, and Takeshita A. Hydrogen peroxide is an endothelium-derived hyperpolarizing factor in mice. J Clin Invest 106: 1521-1530, 2000.

28. Miki T, Suzuki M, Shibasaki T, Uemura H, Sato T, Yamaguchi K, Koseki H, Iwanaga T, Nakaya H, and Seino S. Mouse model of Prinzmetal angina by disruption of the inward rectifier Kir6.1. Nat Med 8: 466-472, 2002.

29. Miura H, Bosnjak JJ, Ning G, Saito T, Miura M, and Gutterman DD. Role for hydrogen peroxide in flow-induced dilation of human coronary arterioles. Circ Res 92: e31-40, 2003.

30. Moreno JM, Rodriguez Gomez I, Wangensteen R, Perez-Abud R, Duarte J, Osuna A, and Vargas F. Mechanisms of hydrogen peroxide-induced 
vasoconstriction in the isolated perfused rat kidney. $J$ Physiol Pharmacol 61: 325332, 2010.

31. Morikawa K, Shimokawa H, Matoba T, Kubota H, Akaike T, Talukder MA, Hatanaka M, Fujiki T, Maeda H, Takahashi S, and Takeshita A. Pivotal role of $\mathrm{Cu}, \mathrm{Zn}$-superoxide dismutase in endothelium-dependent hyperpolarization. $J$ Clin Invest 112: 1871-1879, 2003.

32. Morrison RR, Talukder MA, Ledent C, and Mustafa SJ. Cardiac effects of adenosine in $\mathrm{A}(2 \mathrm{~A})$ receptor knockout hearts: uncovering $\mathrm{A}(2 \mathrm{~B})$ receptors. $\mathrm{Am} J$ Physiol Heart Circ Physiol 282: H437-444, 2002.

33. Nakazaki M, Kakei M, Koriyama N, and Tanaka H. Involvement of ATPsensitive $\mathrm{K}+$ channels in free radical-mediated inhibition of insulin secretion in rat pancreatic beta-cells. Diabetes 44: 878-883, 1995.

34. Nayeem MA, Poloyac SM, Falck JR, Zeldin DC, Ledent C, Ponnoth DS, Ansari HR, and Mustafa SJ. Role of CYP epoxygenases in A2A AR-mediated relaxation using A2A AR-null and wild-type mice. Am J Physiol Heart Circ Physiol 295: H2068-2078, 2008.

35. Nayeem MA, Ponnoth DS, Boegehold MA, Zeldin DC, Falck JR, and Mustafa SJ. High-salt diet enhances mouse aortic relaxation through adenosine A2A receptor via CYP epoxygenases. Am J Physiol Regul Integr Comp Physiol 296: R567$574,2009$.

36. Ng KE, Schwarzer S, Duchen MR, and Tinker A. The intracellular localization and function of the ATP-sensitive K+ channel subunit Kir6.1. J Membr Biol 234: 137-147, 2010. 
37. Olanrewaju HA, Gafurov BS, and Lieberman EM. Involvement of K+ channels in adenosine A2A and A2B receptor-mediated hyperpolarization of porcine coronary artery endothelial cells. J Cardiovasc Pharmacol 40: 43-49, 2002.

38. Olsson RA. Myocardial reactive hyperemia. Circ Res 37: 263-270, 1975.

39. Olsson RA and Gregg DE. Metabolic Responses during Myocardial Reactive Hyperemia in the Unanesthetized Dog. Am J Physiol 208: 231-236, 1965.

40. Pearse DB, Shimoda LA, Verin AD, Bogatcheva N, Moon C, Ronnett GV, Welsh LE, and Becker PM. Effect of cGMP on lung microvascular endothelial barrier dysfunction following hydrogen peroxide. Endothelium 10: 309-317, 2003.

41. Raff U, Ott C, John S, Schmidt BM, Fleischmann EH, and Schmieder RE. Nitric oxide and reactive hyperemia: role of location and duration of ischemia. Am J Hypertens 23: 865-869, 2010.

42. Rogers PA, Chilian WM, Bratz IN, Bryan RM, Jr., and Dick GM. H2O2 activates redox- and 4-aminopyridine-sensitive $\mathrm{Kv}$ channels in coronary vascular smooth muscle. Am J Physiol Heart Circ Physiol 292: H1404-1411, 2007.

43. Rogers PA, Dick GM, Knudson JD, Focardi M, Bratz IN, Swafford AN, Jr., Saitoh S, Tune JD, and Chilian WM. H2O2-induced redox-sensitive coronary vasodilation is mediated by 4 -aminopyridine-sensitive $\mathrm{K}+$ channels. Am J Physiol Heart Circ Physiol 291: H2473-2482, 2006.

44. Rubio R, Berne RM, and Katori M. Release of adenosine in reactive hyperemia of the dog heart. Am J Physiol 216: 56-62, 1969.

45. Saitoh S, Zhang C, Tune JD, Potter B, Kiyooka T, Rogers PA, Knudson JD, Dick GM, Swafford A, and Chilian WM. Hydrogen peroxide: a feed-forward dilator 
that couples myocardial metabolism to coronary blood flow. Arterioscler Thromb Vasc Biol 26: 2614-2621, 2006.

46. Sato A, Terata K, Miura H, Toyama K, Loberiza FR, Jr., Hatoum OA, Saito T, Sakuma I, and Gutterman DD. Mechanism of vasodilation to adenosine in coronary arterioles from patients with heart disease. Am J Physiol Heart Circ Physiol 288: H1633-1640, 2005.

47. Scott JB, Daugherty RM, Jr., Dabney JM, and Haddy FJ. Role of Chemical Factors in Regulation of Flow through Kidney, Hindlimb, and Heart. Am J Physiol 208: 813-824, 1965.

48. Sharifi Sanjani M, Teng B, Krahn T, Tilley SL, Ledent C, and Mustafa SJ. Contributions of $\mathrm{A} 2 \mathrm{~A}$ and $\mathrm{A} 2 \mathrm{~B}$ adenosine receptors in coronary flow responses in relation to KATP channel using $\mathrm{A} 2 \mathrm{~B}$ and $\mathrm{A} 2 \mathrm{~A} / 2 \mathrm{~B}$ double knockout mice. Am $J$ Physiol Heart Circ Physiol, 2011.

49. Talukder MA, Morrison RR, Ledent C, and Mustafa SJ. Endogenous adenosine increases coronary flow by activation of both A2A and A2B receptors in mice. J Cardiovasc Pharmacol 41: 562-570, 2003.

50. Teng B, Ledent $C$, and Mustafa SJ. Up-regulation of A $2 B$ adenosine receptor in A $2 \mathrm{~A}$ adenosine receptor knockout mouse coronary artery. J Mol Cell Cardiol 44: 905-914, 2008.

51. Thengchaisri N, Hein TW, Wang W, Xu X, Li Z, Fossum TW, and Kuo L. Upregulation of arginase by $\mathrm{H} 2 \mathrm{O2}$ impairs endothelium-dependent nitric oxidemediated dilation of coronary arterioles. Arterioscler Thromb Vasc Biol 26: 20352042, 2006. 
52. Tsunoda $R$, Okumura $K$, Ishizaka H, Matsunaga T, Tabuchi T, Tayama S, and Yasue H. Enhancement of myocardial reactive hyperemia with manganesesuperoxide dismutase: role of endothelium-derived nitric oxide. Cardiovasc Res 31: 537-545, 1996.

53. Tune JD, Gorman MW, and Feigl EO. Matching coronary blood flow to myocardial oxygen consumption. J Appl Physiol 97: 404-415, 2004.

54. Varma SD and Devamanoharan PS. Hydrogen peroxide in human blood. Free Radic Res Commun 14: 125-131, 1991.

55. Wei EP, Kontos HA, and Beckman JS. Mechanisms of cerebral vasodilation by superoxide, hydrogen peroxide, and peroxynitrite. Am J Physiol 271: H12621266, 1996.

56. Wilson SJ and Keenan AK. Role of hemin in the modulation of H2O2mediated endothelial cell injury. Vascul Pharmacol 40: 109-118, 2003.

57. Wolin MS, Rodenburg JM, Messina EJ, and Kaley G. Similarities in the pharmacological modulation of reactive hyperemia and vasodilation to hydrogen peroxide in rat skeletal muscle arterioles: effects of probes for endothelium-derived mediators. J Pharmacol Exp Ther 253: 508-512, 1990.

58. Yada T, Shimokawa H, Hiramatsu O, Kajita T, Shigeto F, Goto M, Ogasawara Y, and Kajiya F. Hydrogen peroxide, an endogenous endotheliumderived hyperpolarizing factor, plays an important role in coronary autoregulation in vivo. Circulation 107: 1040-1045, 2003.

59. Yada T, Shimokawa H, Hiramatsu O, Shinozaki Y, Mori H, Goto M, Ogasawara Y, and Kajiya F. Important role of endogenous hydrogen peroxide in 
pacing-induced metabolic coronary vasodilation in dogs in vivo. $\mathrm{J}$ Am Coll Cardiol 50: 1272-1278, 2007.

60. Yada T, Shimokawa H, Morikawa K, Takaki A, Shinozaki Y, Mori H, Goto M, Ogasawara Y, and Kajiya F. Role of Cu,Zn-SOD in the synthesis of endogenous vasodilator hydrogen peroxide during reactive hyperemia in mouse mesenteric microcirculation in vivo. Am J Physiol Heart Circ Physiol 294: H441-448, 2008.

61. Yamabe H, Okumura K, Ishizaka H, Tsuchiya T, and Yasue H. Role of endothelium-derived nitric oxide in myocardial reactive hyperemia. Am J Physiol 263: H8-14, 1992.

62. Zatta AJ and Headrick JP. Mediators of coronary reactive hyperaemia in isolated mouse heart. Br J Pharmacol 144: 576-587, 2005. 
CHAPTER FIVE CONCLUSION 
The work presented in this dissertation confirms the heterogeneity of coronary flow responses mediated by activation of adenosine receptors (AR). In this dissertation, we established that $\mathrm{A}_{2 \mathrm{~A} / \mathrm{B}} \mathrm{AR}$ subtypes may have differing contributions in the regulation of CF under varying conditions.

We suggested that out of all four $A R$ subtypes, $A_{2 A} A R s$ and $A_{2 B} A R s$ induce coronary artery (CA) vasodilation, since exogenous adenosine did not induce any increase in $\mathrm{CF}$ in $\mathrm{A}_{2 \mathrm{~A} / 2 \mathrm{~B}} \mathrm{AR}$ double knockout mice. Additionally, each of these two $\mathrm{AR}$ subtypes further compensate for the deletion of the other subtype; indeed $\mathrm{A}_{2 \mathrm{~A}} \mathrm{ARs}$ expression was up-regulated in $\mathrm{A}_{2 \mathrm{~B}} \mathrm{KO}$ mice. We established the presence of such compensatory mechanism via the use of selective and non-selective agonists and antagonists. Furthermore, since some inconsistencies are reported between the results obtained from pharmacological and molecular (knockout mice) approaches, we also used AR knockout mice to further confirm our findings. The differing expression of $A_{2 A} / 2 B$ ARs is reported in many cardiovascular diseases and, therefore, the knowledge of the presence of such compensatory mechanisms between $\mathrm{A}_{2 \mathrm{~A}}$ and $\mathrm{A}_{2 \mathrm{~B}} \mathrm{ARs}$ may contribute to the future development of new treatment approaches. In fact, $\mathrm{A}_{2} \mathrm{ARs}$ are being investigated as a treatment during percutaneous coronary intervention for the reduction of myocardial reperfusion injury in patients with myocardial infarction, which is well established to be associated with worsening of cardiac injury and function.

The next step was to determine the effector, located on SMCs, causing the final effect of coronary vasodilation mediated by activation of $\mathrm{A}_{2} \mathrm{ARs}$. We not only learned that both $\mathrm{A}_{2 \mathrm{~A}} \mathrm{AR}$ - and $\mathrm{A}_{2 \mathrm{~B}} \mathrm{AR}$-mediated $\mathrm{CF}$ effects are via activation of nonmitochondrial $\mathrm{K}_{\mathrm{ATP}}$ channels but, we suggest that, no matter what the $\mathrm{A}_{2} \mathrm{AR}$-induced coronary vasodilation signaling pathway may be, it may be through activation of $\mathrm{K}_{\mathrm{ATP}}$ 
channels since both $\mathrm{A}_{2 \mathrm{~A}} \mathrm{AR}$ - and $\mathrm{A}_{2 \mathrm{~B}} \mathrm{AR}$-meditaed $\mathrm{CF}$ effects were abolished in the presence of glibenclamide (Figure 3.7).

Whereas we showed that activation of both $\mathrm{A}_{2 \mathrm{~A}} \mathrm{ARs}$ and $\mathrm{A}_{2 \mathrm{~B}} \mathrm{ARs}$ induces $\mathrm{CF}$ vasodilation, in this dissertation we established that only $\mathrm{A}_{2 \mathrm{~A}} \mathrm{ARs}$ contribute to the regulation of $\mathrm{CF}$ in reactive hyperemia, where the metabolic factors are known to be mainly involved. It is interesting to mention that $\mathrm{A}_{2 \mathrm{~A}} \mathrm{ARs}$ induce the sustained coronary vasodilation during reactive hyperemia through the release of $\mathrm{H}_{2} \mathrm{O}_{2} \cdot \mathrm{H}_{2} \mathrm{O}_{2}$, depending on the vascular bed and its concentration, acts as a vasorelaxing as well as a vasoconstricting factor. Using isolated mouse hearts, we showed that exogenous $\mathrm{H}_{2} \mathrm{O}_{2}$ may have a tissueprotective role by inducing coronary vasodilation. In addition, we established that $\mathrm{H}_{2} \mathrm{O}_{2}$, released due to activation of $\mathrm{A}_{2 \mathrm{~A}} \mathrm{ARs}$, also activates $\mathrm{K}_{\mathrm{ATP}}$ channels on smooth muscle cells, which further confirms our findings that $\mathrm{K}_{\mathrm{ATP}}$ channels may be the end effector in $\mathrm{A}_{2} \mathrm{AR}$-mediated effect on CF (Figure 5.1).

The availability of single and double knockout ARs is a valuable tool to better understand the role of each AR or a subclass of AR subtype. In addition to measurement of baseline parameters, such as baseline $\mathrm{CF}$, heart rate, and left ventricle developed pressure, we also showed that the recently available $\mathrm{A}_{2 \mathrm{~B}} \mathrm{KO}$ mice have a functional endothelium by showing that bradykinin response was not different in $\mathrm{A}_{2 \mathrm{~B}} \mathrm{KO}$ mice compared with wild type mice.

In summary, both $\mathrm{A}_{2 \mathrm{~A}}$ and $\mathrm{A}_{2 \mathrm{~B}} \mathrm{ARs}$ are capable of inducing coronary vasodilation, but they each are activated endogenously under different conditions. Needless to say, the role of $\mathrm{A}_{2} \mathrm{ARs}$ in the regulation of $\mathrm{CF}$ is much more complicated than what has been described in this thesis. It is possible that there might also be other interactions present between this class of GPCRs and $\beta$ adrenoceptors, in view of the fact 
that NECA-mediated increase in $\mathrm{CF}$ is ameliorated in $\beta_{1} / \beta_{2}$ double knockout mice (Appendix A). These findings require more detailed investigation to better understand the interaction between ARs and $\beta$ adrenoceptors. 
Figure 5.1 Suggested signaling pathways for $A_{2 A^{-}}$and $A_{2 B}$ ARs-mediated $C F$ regulation

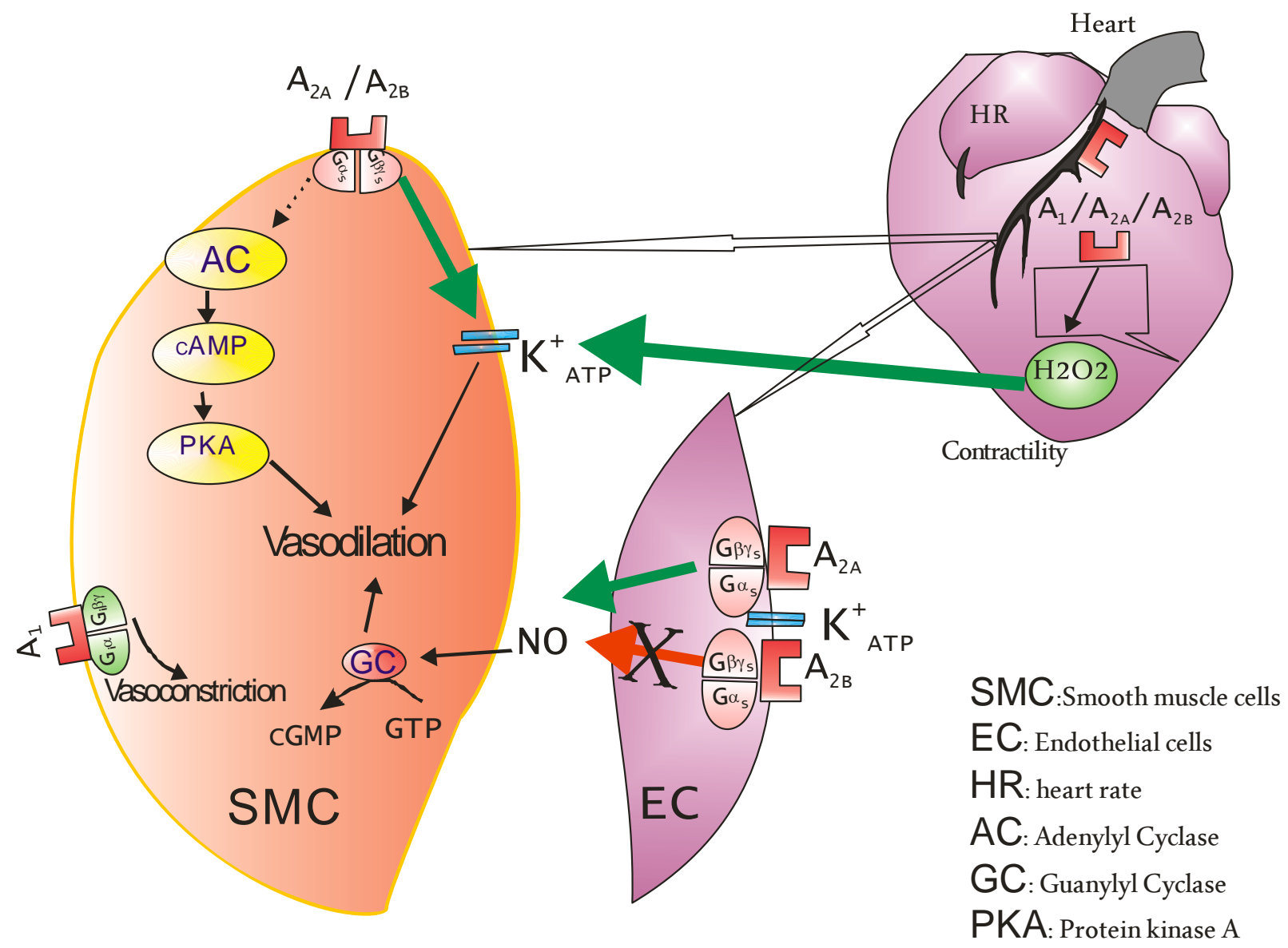




\section{Future Directions}

The next step for this project would be to identify the source of $\mathrm{H}_{2} \mathrm{O}_{2} ; \mathrm{H}_{2} \mathrm{O}_{2}$ may be released from the myocardium or the vascular bed itself, in which case, the knowledge of whether the source is the endothelium or SMCs may help us to identify the mechanism behind reduced adenosine coronary response in patients with cardiovascular disease. Furthermore, it would be interesting to identify the factor(s) responsible for the release of superoxide, which subsequently leads to the formation of $\mathrm{H}_{2} \mathrm{O}_{2}$; among the possible factors, NADPH oxidases and mitochondria are the primary candidate sources of superoxides (Figure 5.2).

The NADPH oxidase-enzyme complex consists of two membrane-bound components (gp91phox [also known as NADPH oxidase (Nox)-2] and p22phox) and several cytosolic regulatory subunits, including p47phox, p67phox, and the small GTPase Rac (Rac1 or Rac2). When NADPH oxidase becomes activated, the cytoplasmic subunits translocate to the cell membrane and the resulting complex transfers electrons from NADPH to molecular oxygen in order to form superoxide. In fact, NADPH oxidase is identified as a major source of superoxide in ECs, and, therefore, the important determinants of the oxidation-reduction (redox) state of the endothelium. Investigators have also identified NADPH oxidase complex as the major source of ROS in VSMCs. Whereas both p22phox and p47phox appear to be essential for NADPH oxidase activity in VSMCs, targeted-deletion of the gp91phox gene in mice had no effect on superoxide production (3). Additionally, two homologues of gp91phox, termed Nox1 and Nox4, are suggested to be mainly present on vascular beds. Therefore, the association of the NADPH oxidase homologue involved in adenosine-mediated release of $\mathrm{H}_{2} \mathrm{O}_{2}$, and hence coronary vasodilation, needs to be clarified. 
In many cells, the majority of superoxide is generated from mitochondria via cellular respiration and specifically during ubisemiquinone autoxidation. Ubisemiquinone can serve as an electron donor to $\mathrm{O}_{2}$ to produce superoxide. Electron flow through the mitochondrial electron transfer chain occurs by four inner membrane-associated enzyme complexes, with cytochrome $\mathrm{c}$ and the mobile carrier ubiquinone. NADH derived from both cytosol and mitochondria donate electrons to NADH:ubiquinone oxidoreductase (complex I) which then transfers its electrons to succinate:ubiquinone oxidoreductase (complex II). Electrons from reduced ubiquinone are then transferred to ubiquinol:cytochrome c oxidoreductase (complex III). Electron transport then proceeds through cytochrome c, cytochrome c oxidase (complex IV), and finally, molecular oxygen (5-6). Nevertheless, there are two major mitochondrial electron transfer chain regions where ROS are produced: complex I and complex III. Therefore, in order to identify the mitochondrial complex involved in $\mathrm{H}_{2} \mathrm{O}_{2}$ production, we can use rotenone, a complex I inhibitor, myxothiazol, which inhibits oxidation of ubiquinol to ubisemiquinone in complex III, and cyanide, a complex IV inhibitor, to detect if the trapped radical species originates from the electron transport chain of the mitochondria.

Cardioprotective effect of carvedilol ( $\beta$ ADR blocker) was shown to be through an adenosine-dependent mechanism. Additionally, it was reported that $\beta$ ADR-mediated inotropic responses were attenuated by adenosine (7). Our preliminary data also establishes a relationship between $\beta A D R s$ and $A_{2} A R s$ since the effect of NECA is attenuated in $\beta_{1} / \beta_{2} \mathrm{DKO}$ mice. Therefore, a better understanding of the relationship between ARs and $\beta A D R s$ in $C F$ regulation and the possible signaling pathways involved, would open a new window to better understand the heterogeneity $\mathrm{CF}$ regulation in relation to ARs. Our preliminary data show that, like any complex system, regulation of 
CF may further involve an interaction between ARs and $\beta A D R s$. Nevertheless, this investigation requires further experiments to confirm the presence of such a relationship between these two classes of GPCRs.

Finally, our data show that $\mathrm{A}_{2 \mathrm{~B}} \mathrm{ARs}$ are not involved in $\mathrm{RH}$ and may play a role in severe ischemic conditions, where adenosine levels are significantly higher. Therefore, in order to better clarify the role of $\mathrm{A}_{2 \mathrm{~B}} \mathrm{ARs}$ in $\mathrm{CF}$ regulation, further experiments such as ischemia/reperfusion experiments are needed. Indeed, is has been reported that $A_{2 B} A R s$ play a cardioprotective role during ischemia/reperfusion (1-2, 4). Therefore, taken together, elucidation of $\mathrm{CF}$ regulation and cardioprotection in light of $\mathrm{A}_{2 \mathrm{~B}} \mathrm{ARs}$ and $\beta A D R s$, and, ultimately, understanding the signaling pathways involved, would lead to uncovering of the translational mechanisms of cardiac reperfusion subsequent to a heart attack, in addition to finding of better and complete ways of cardiac imaging evaluation for the diagnosis of coronary artery disease (Figure 5.2). 
Figure 5.2 Future directions for identifications of $A_{2 \mathrm{~A}} \mathrm{ARs}$ and $\mathrm{A}_{2 \mathrm{~B}} \mathrm{ARs}$ signaling pathways in the regulation of $\mathrm{CF}$

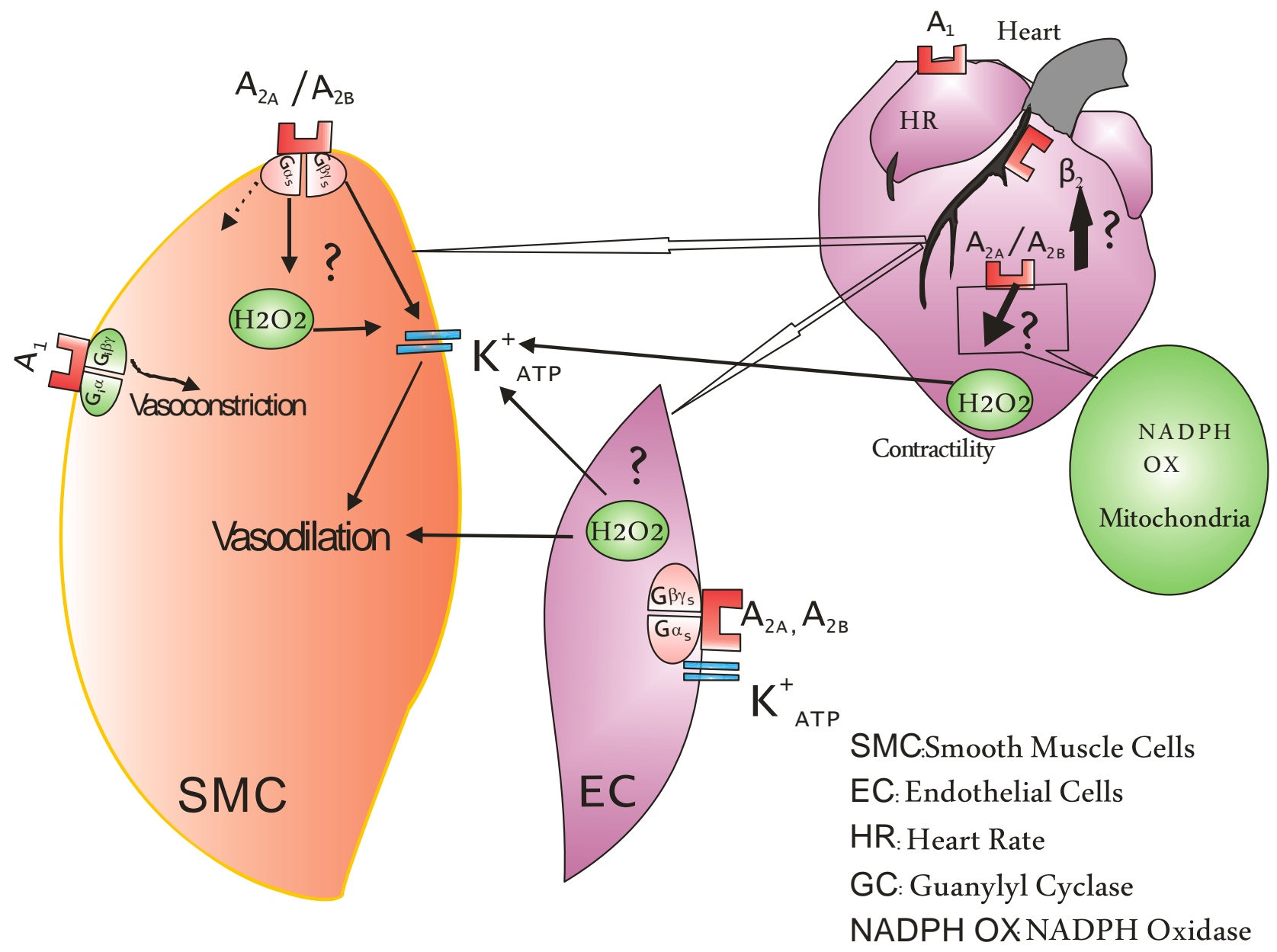




\section{References}

1. Eckle T, Faigle M, Grenz A, Laucher S, Thompson LF, and Eltzschig HK. A2B adenosine receptor dampens hypoxia-induced vascular leak. Blood 111: 20242035, 2008.

2. Eckle T, Kohler D, Lehmann R, El Kasmi K, and Eltzschig HK. Hypoxiainducible factor-1 is central to cardioprotection: a new paradigm for ischemic preconditioning. Circulation 118: 166-175, 2008.

3. Feng J, Damrauer SM, Lee M, Sellke FW, Ferran C, and Abid MR. Endothelium-dependent coronary vasodilation requires NADPH oxidase-derived reactive oxygen species. Arterioscler Thromb Vasc Biol 30: 1703-1710, 2010.

4. Headrick JP and Lasley RD. Adenosine receptors and reperfusion injury of the heart. Handb Exp Pharmacol: 189-214, 2009.

5. Murphy E, Bers D, and Rizzuto R. Mitochondria: from basic biology to cardiovascular disease. J Mol Cell Cardiol 46: 765-766, 2009.

6. Murphy MP. How mitochondria produce reactive oxygen species. Biochem J 417: 1-13, 2009.

7. Sato H, Hori M, Kitakaze M, Takashima S, Inoue M, Kitabatake A, and Kamada T. Endogenous adenosine blunts beta-adrenoceptor-mediated inotropic response in hypoperfused canine myocardium. Circulation 85: 1594-1603, 1992. 


\section{PUBLICATIONS}

I. Dovenia S. Ponnoth, Maryam Sharifi Sanjani, Catherine Ledent, Kevin Roush, Thomas Krahn and S. Jamal Mustafa. Absence of adenosine-mediated aortic relaxation in $\mathrm{A}_{2 \mathrm{~A}}$ adenosine receptor knockout mice. Am J Physiol Heart Circ Physiol. 2009 Nov; 297(5):H1655-60. PMID: 19749167

II. Maryam Sharifi Sanjani, Bunyen Teng, Thomas Krahn, Stephen Tilley, Catherine Ledent and S. Jamal Mustafa. Contributions of $A_{2 A}$ and $A_{2 B}$ adenosine receptors in coronary flow responses in relation to $K_{A T P}$ channel using $A_{2 B}$ and $\mathrm{A}_{2 \mathrm{~A} / 2 \mathrm{~B}}$ double knockout mice. Am J Physiol Heart Circ Physiol. 2011 Sep; PMID: 21949117

III. El-Awady MS, Sharifi MS, Mustafa SJ. "Adenosine receptors and the heart: role in regulation of coronary blood flow" Proceedings of the "9th International Congress on Coronary Artery Disease" Pub: Medimond, pages 9-16, 2011.

IV. Maryam Sharifi Sanjani, Shinichi Asano, Gregory Dick, Bunyen Teng, Stephen Tilley, Catherine Ledent and S. Jamal Mustafa. Interaction of adenosine $\mathrm{A}_{2 \mathrm{~A}}$ receptors, hydrogen peroxide, and ATP-dependent $\mathrm{K}^{+}$channels in coronary reactive hyperemia (Under Review)

\section{Abstracts and Presentations}

Oral

1. Maryam Sharifi Sanjani, Bunyen Teng, Stephen Tilley, S. Jamal Mustafa. Understanding the role of $\mathrm{A}_{2 \mathrm{~B}}$ adenosine receptor using knockout in the regulation of coronary flow. American Heart Association (AHA) Fellows Research Day: University of Pittsburgh Medical Center (February 2009)

$\underline{\text { Poster }}$

1. Maryam Sharifi Sanjani, Bunyen Teng, Thomas Krahn, Stephen Tilley, Catherine Ledent and S. Jamal Mustafa. Relationship between $\mathrm{H}_{2} \mathrm{O}_{2}$ and $\mathrm{A}_{2}$ adenosine receptor in reactive hyperemia in isolated mouse heart. Experimental Biology, Washington D.C. (April, 2011)

2. Maryam Sharifi Sanjani, Bunyen Teng, Thomas Krahn, Stephen Tilley, Catherine Ledent and S. Jamal Mustafa. Relationship between $\mathrm{H}_{2} \mathrm{O}_{2}$ and $\mathrm{A}_{2}$ adenosine receptor in reactive hyperemia in isolated mouse heart. Van Lier Research Day West Virginia University (March, 2011)

3. Maryam Sharifi Sanjani, Bunyen Teng, Thomas Krahn, Stephen Tilley, Catherine Ledent and S. Jamal Mustafa. Involvement of $\mathrm{H}_{2} \mathrm{O}_{2}$ in adenosinemediated regulation of coronary flow (IUPHAR 2010, Paper No. 2222). WorldPharma 2010, Copenhagen, Denmark (July 2010) 
4. Maryam Sharifi Sanjani, Dovenia Ponnoth, Kevin Roush, Steve Tilley, S. Jamal Mustafa. Evidence for the role of $\mathrm{A}_{2 \mathrm{~B}}$ adenosine receptor in the regulation of vascular tone using $\mathrm{A}_{2 \mathrm{~B}} \mathrm{KO}$ mice (FASEB J. 2009 23:1032.2). Experimental Biology, Anaheim, 2010 (April, 2010)

5. Maryam Sharifi Sanjani, Dovenia Ponnoth, Kevin Roush, Steve Tilley, S. Jamal Mustafa. Evidence for the role of $\mathrm{A}_{2 \mathrm{~B}}$ adenosine receptor in the regulation of vascular tone using $\mathrm{A}_{2 \mathrm{~B}} \mathrm{KO}$ mice. Van Lier Research Day West Virginia University (April 2010)

6. Maryam Sharifi Sanjani, Stephen Tilley, Bunyen Teng, S. Jamal Mustafa. Understanding the role of $\mathrm{A}_{2 \mathrm{~B}}$ adenosine receptor using knockout in the regulation of coronary flow (FASEB J. 2010 24:958.2) Experimental Biology, New Orleans, 2009 (April, 2009)

7. Maryam Sharifi Sanjani, Stephen Tilley, Bunyen Teng, S. Jamal Mustafa. Role of $A_{2 B}$ adenosine receptor in the regulation of coronary flow. Van Lier Research Day West Virginia University (April 2009)

8. Maryam Sharifi Sanjani, Bunyen Teng, Stephen Tilley, S. Jamal Mustafa. Role of $\mathrm{A}_{2 \mathrm{~B}}$ adenosine receptor in the regulation of coronary flow. Van Lier Research Day West Virginia University (April 2008) 


\section{APPENDIX A}

Preliminary experiments (relationship between adenosine receptors and $\beta_{1}$ and $\beta_{2}$ adrenoceptors) were carried out. The concentration-response curve for NECA was calculated in WT (FVB) and $\beta_{2} \mathrm{KO}$ mice isolated hearts. This was done to determine the role of $\mathrm{A}_{2} \mathrm{ARs}$ in NECA-induced relaxation in $\beta_{2} \mathrm{KO}$. There was no difference between the two groups.
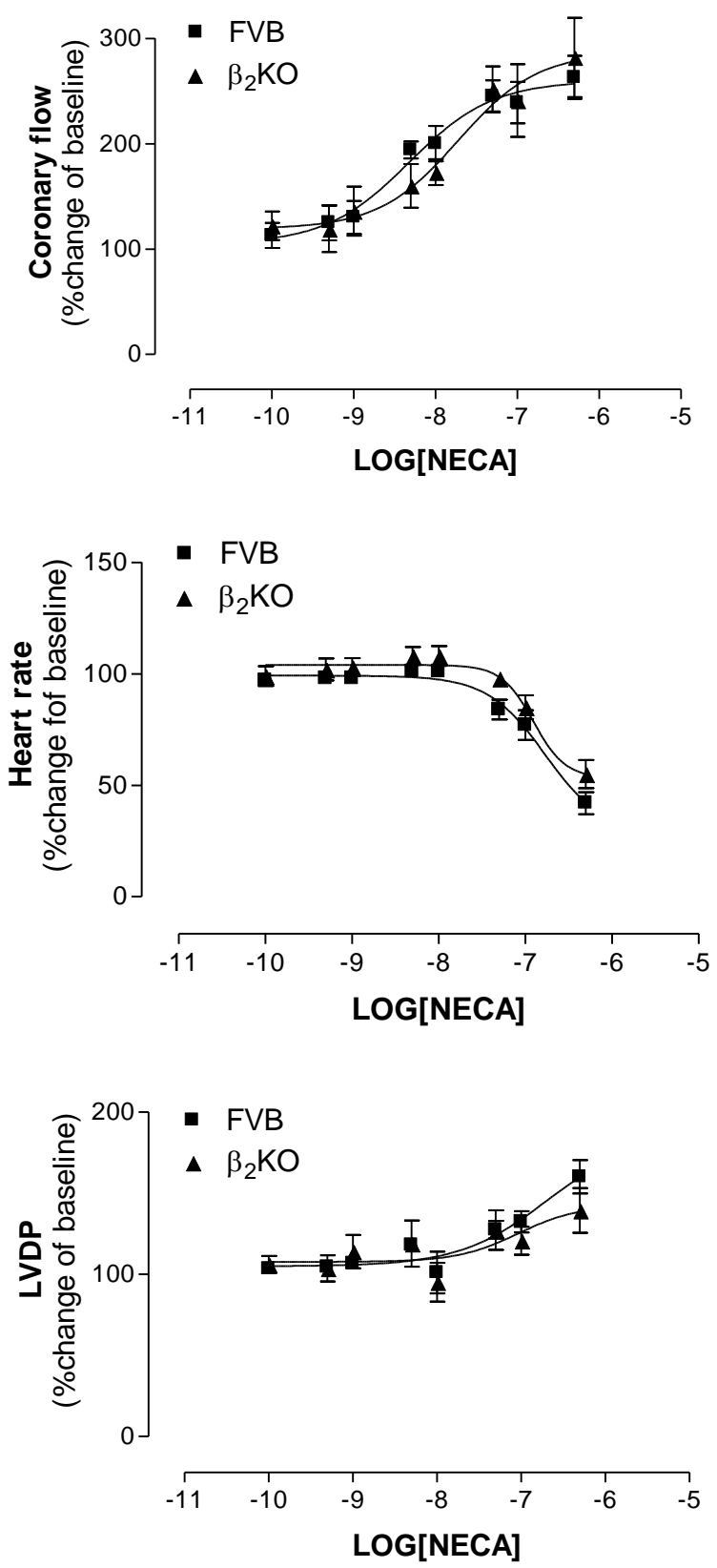
Preliminary experiments (relationship between adenosine receptors and $\beta_{1}$ and $\beta_{2}$ adrenoceptors) were carried out. The concentration-response curve for NECA was calculated in WT (FVB), WT (C57), and $\beta_{1 / 2} \mathrm{DKO}$ mice isolated hearts. This was done to determine the role of $\mathrm{A}_{2} \mathrm{ARs}$ in NECA-induced relaxation in $\beta_{1 / 2} \mathrm{DKO}$. There was no difference between the two control groups while NECA-mediated effects were significantly diminished in $\beta_{1 / 2} D K O$ compared to both controls.
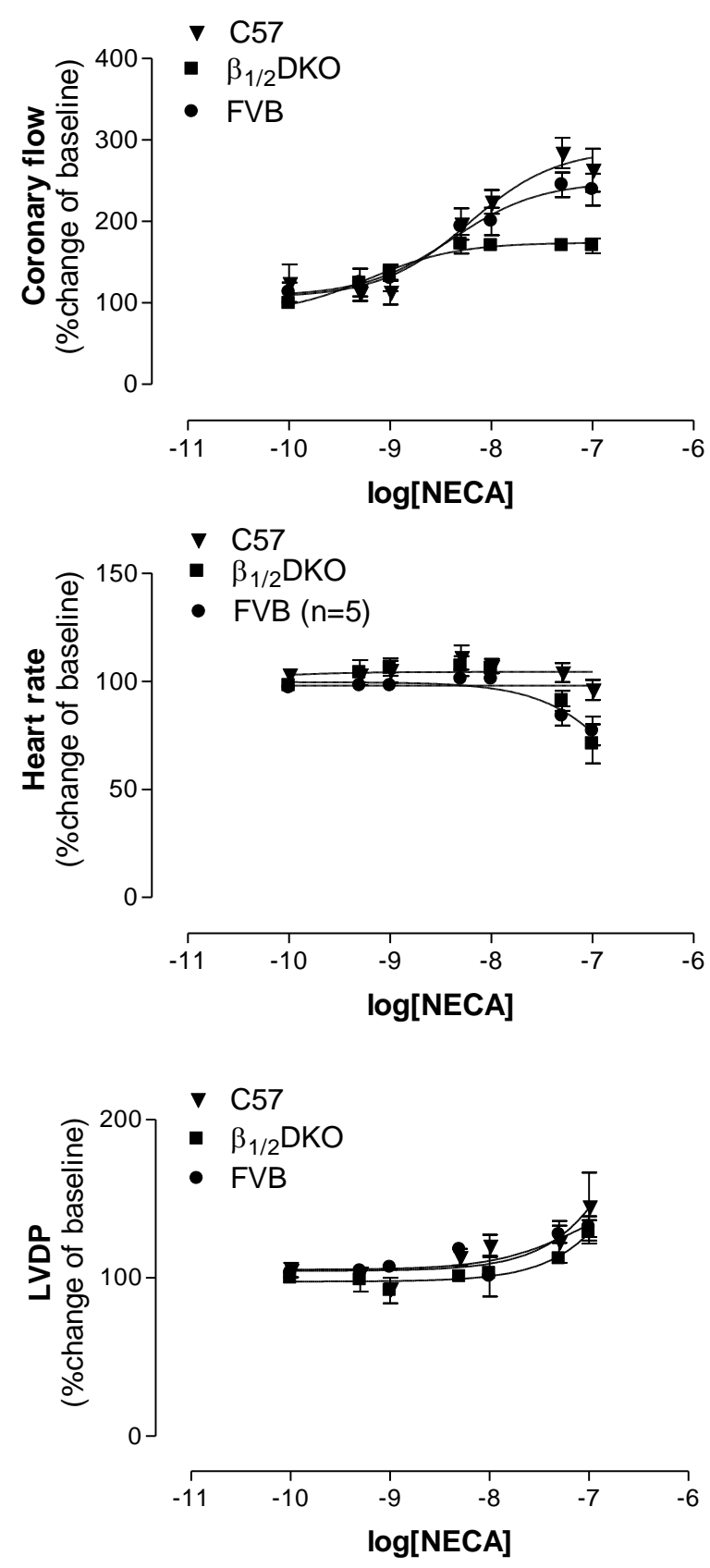
Preliminary experiments (relationship between adenosine receptors and $\beta_{1}$ and $\beta_{2}$ adrenoceptors) were carried out. The concentration-response curve for CCPA was calculated in WT (FVB) and $\beta_{1 / 2}$ DKO mice isolated hearts. This was done to determine the role of $A_{1} \mathrm{AR}$-mediated effect in $\beta_{1 / 2} \mathrm{DKO}$. There was no difference between the two groups.
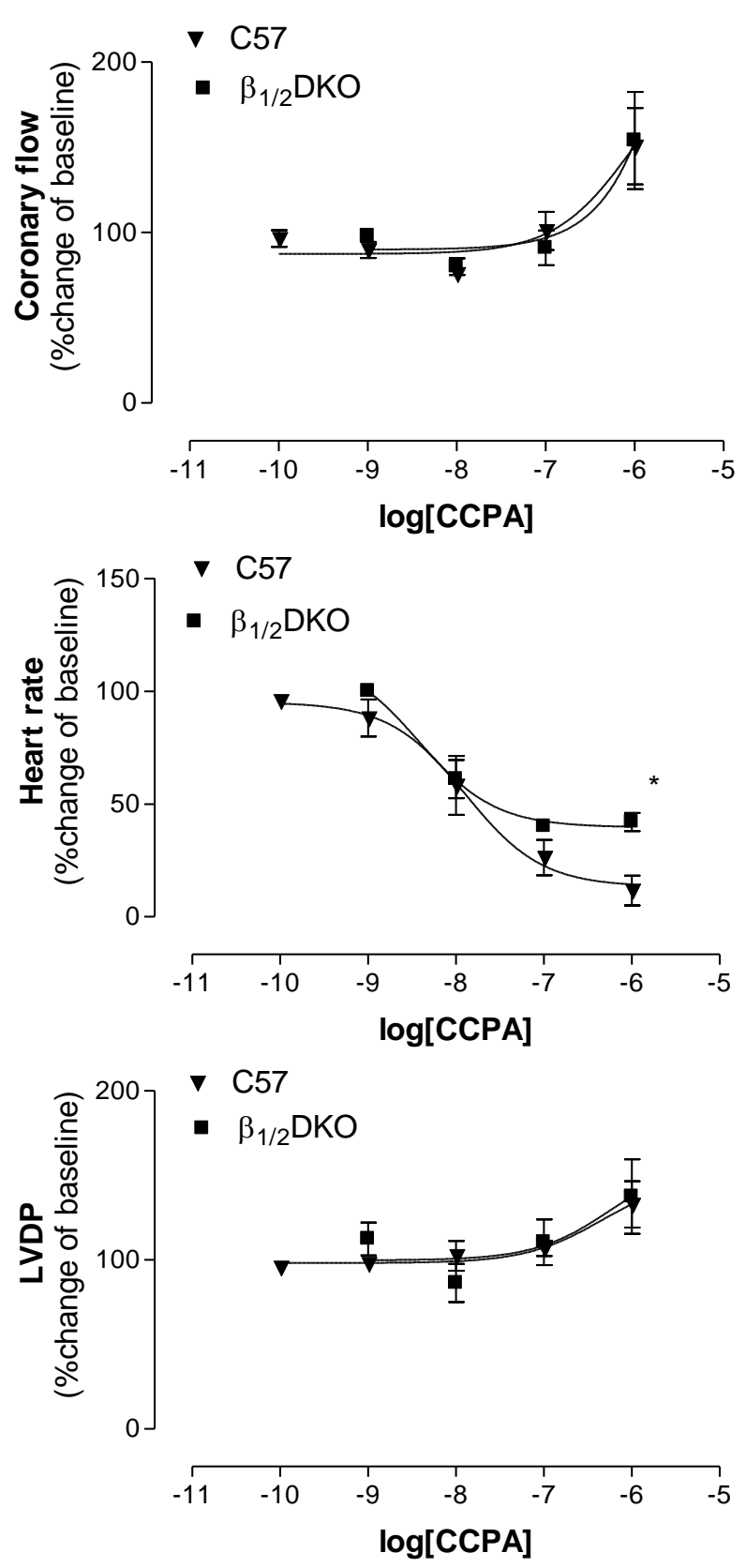


\section{APPENDIX B}

\section{American Journal of Physiology copyright permission}

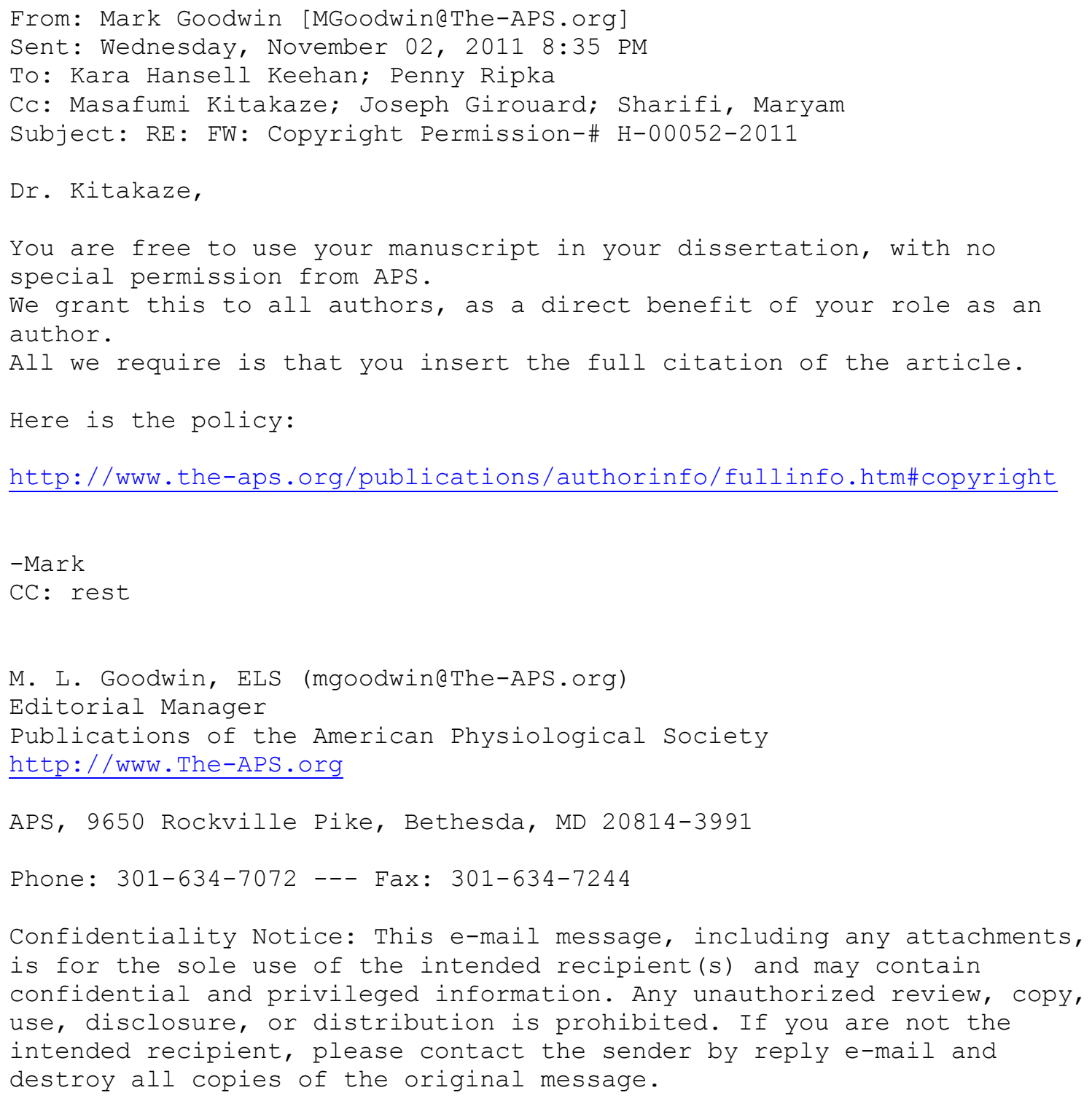




\section{APPENDIX C}

\section{CURRICULUM VITAE}

\section{Education}

2006-Present Ph.D. Candidate Pharmaceutical \& Pharmacological Sciences

2001-2003 M.Sc.

1996-2000 B.Sc.

Advisor: Dr. S. Jamal Mustafa

Dissertation title: Role and contribution of $\mathrm{A}_{2}$ adenosine receptors in the regulation of Position coronary flow

2006-present

Graduate Assistant, Center for Cardiovascular and Respiratory Sciences, Department of Physiology \& Pharmacology, West Virginia University, Morgantown, WV

\section{Teaching Experience}

2008-Present

I am a facilitator in Pharmacology Additional Learning Exercise (ALE) for medical students conducted by the School of Medicine, West Virginia University.

2009

I have guided and taught methods and approaches to one undergraduate student for a 9-week summer research project.

2011

I have taken Teaching Practicum courses and have lectured Cardiac Physiology.

\section{Grants}

1. Recipient of NIH Cardiovascular and Pulmonary Disease training grant (NHLBIT32 Pre-Doctoral training grant), July 2008-July 2011

2. Applied for American Heart Association Predoctoral Fellowship (2010 Great Rivers Affiliate) (not funded) "Interplay between $\mathrm{A}_{2}$ adenosine receptors, $\beta_{2}$ adrenergic receptors, and $\mathrm{H}_{2} \mathrm{O}_{2}$ in the regulation of coronary flow" 


\section{Professional Honors and Awards}

1. Recipient of WorldPharma 2010 (16th IUPHAR WorldCongress of Basic and Clinical Pharmacology) ASPET travel award: March 2010

2. Recipient of Department of Pharmaceutical and Pharmacological Sciences (West Virginia University) travel award: February 2010

3. Recipient of Research Graduate Office (West Virginia University) travel award: January 2010

4. Recipient of American Heart Association (AHA) Fellows Research Day award: February 2009

5. Recipient of Department of Pharmaceutical and Pharmacological Sciences (West Virginia University) travel award: February 2009

6. Recipient of Department of Pharmaceutical and Pharmacological Sciences (West Virginia University) travel award: February 2008

\section{Professional Membership}

American Society for Pharmacology and Experimental Therapeutics (ASPET)

The American Physiological Society (APS)

\section{Participation in Scientific Meetings}

2011

2010

2010

2010

2009

2009
Experimental Biology, Washington D.C.

American Heart Association, Chicago, IL

WorldPharma 2010 (16th IUPHAR WorldCongress

of Basic and Clinical Pharmacology, Copenhagen, Denmark

Experimental Biology, Anaheim, CA

American Heart Association (AHA) Fellows Research Day, Pittsburgh, PA

Experimental Biology, New Orleans, LA

\section{John H.

